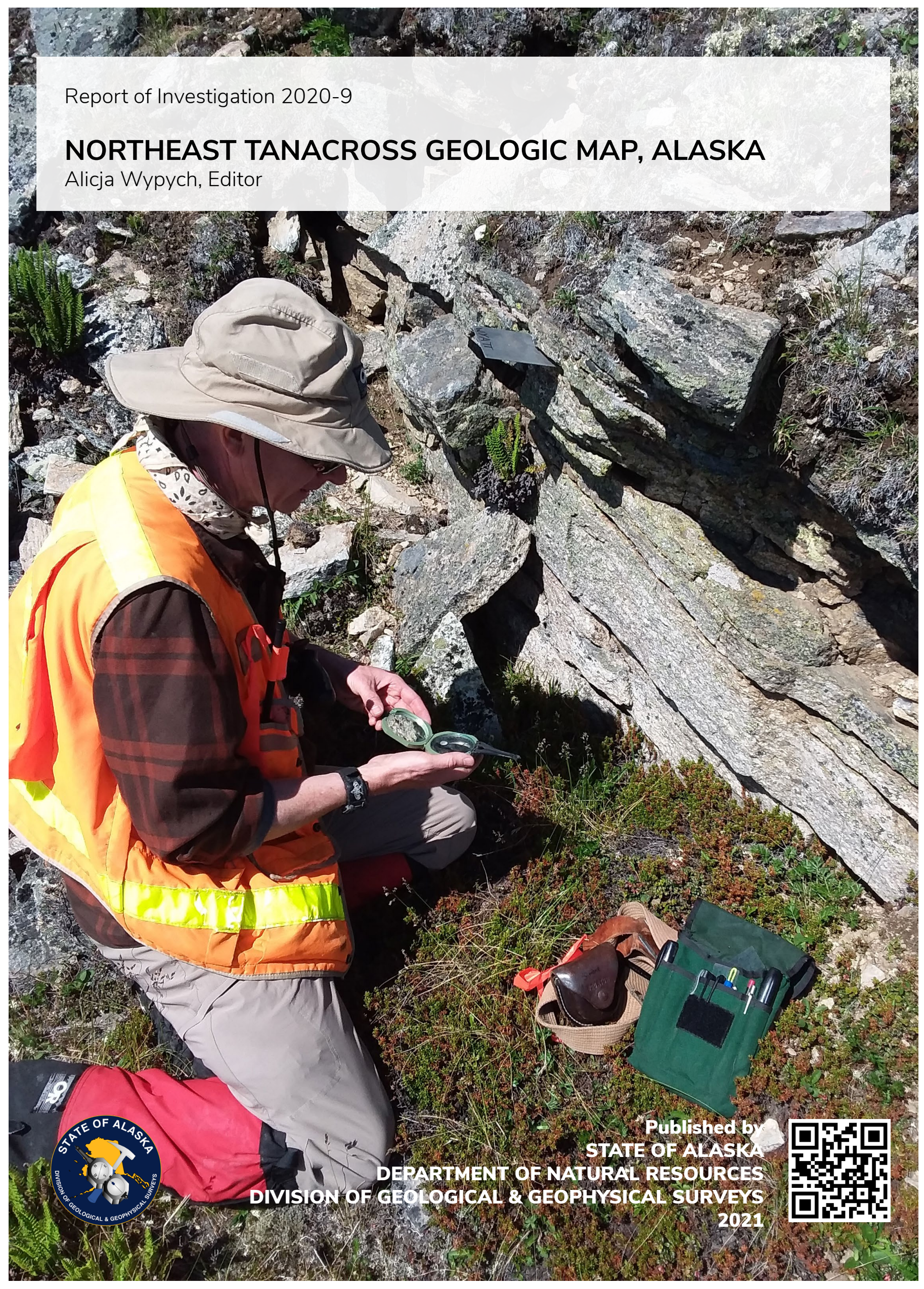


Cover. DGGS geologist Chris Wyatt on an outcrop of sheared Divide Mountain augen gneiss. Photo: Alicja Wypych. 


\section{NORTHEAST TANACROSS GEOLOGIC MAP, ALASKA}

Alicja Wypych, Editor

Report of Investigation 2020-9

State of Alaska

Department of Natural Resources

Division of Geological \& Geophysical Surveys 


\section{STATE OF ALASKA}

Mike Dunleavy, Governor

\section{DEPARTMENT OF NATURAL RESOURCES}

Corri A. Feige, Commissioner

\section{DIVISION OF GEOLOGICAL \& GEOPHYSICAL SURVEYS}

Steve Masterman, State Geologist and Director

Publications produced by the Division of Geological \&

Geophysical Surveys (DGGS) are available for free download

from the DGGS website (dggs.alaska.gov). Publications on

hard-copy or digital media can be examined or purchased in

the Fairbanks office:

Alaska Division of Geological \& Geophysical Surveys

3354 College Rd., Fairbanks, Alaska 99709-3707

Phone: (907) 451-5010 Fax (907) 451-5050

dggspubs@alaska.gov|dggs.alaska.gov

\section{DGGS publications are also available at:}

Alaska State Library,

Historical Collections \& Talking Book Center

395 Whittier Street

Juneau, Alaska 99811

Alaska Resource Library and Information Services (ARLIS)

3150 C Street, Suite 100

Anchorage, Alaska 99503

\section{Suggested citation:}

Wypych, Alicja, ed., 2021, Northeast Tanacross geologic mapping project, Alaska: Alaska Division of Geological \& Geophysical Surveys Report of Investigation 2020-9, 75 p. https://doi.org/10.14509/30537
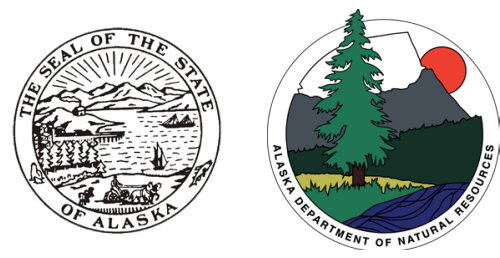


\section{Contents}

Chapter A: Introduction to the Northeast Tanacross Geologic Map ..........................................................

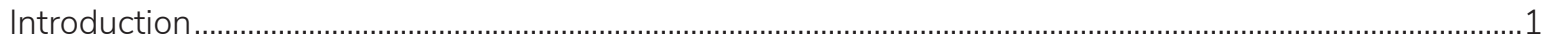

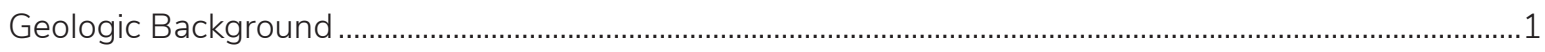

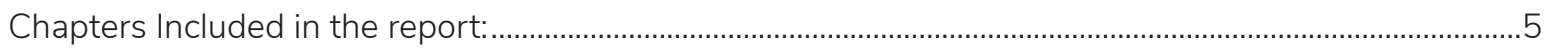

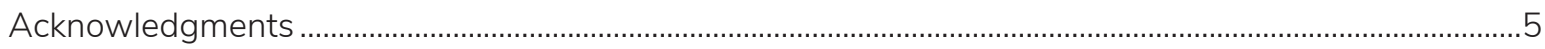

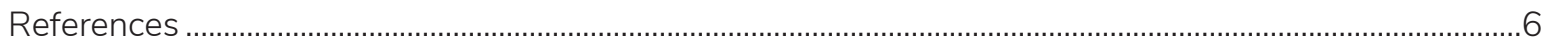

Chapter B: Northeast Tanacross Geologic Map and Map Units and Descriptions......................................9

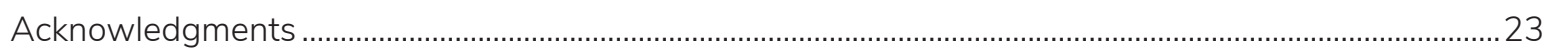

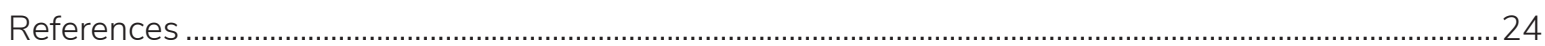

Chapter C: Metamorphic Cooling History of the Fortymile River and Lake George

Assemblages from ${ }^{40} \mathrm{Ar} /{ }^{39} \mathrm{Ar}$ Geochronology from the Northeast Tanacross and Southeast

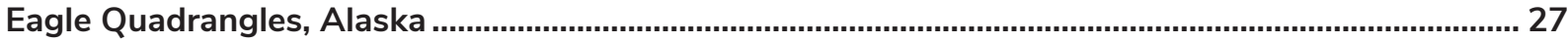

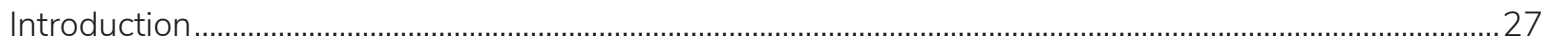

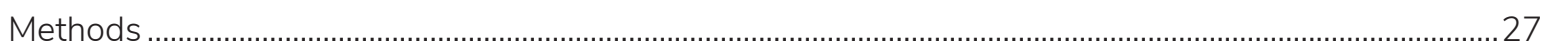

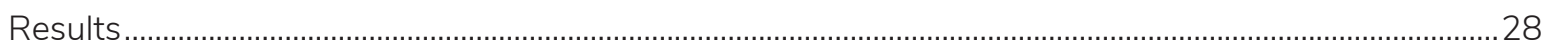

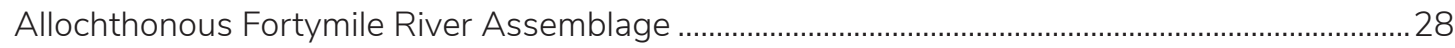

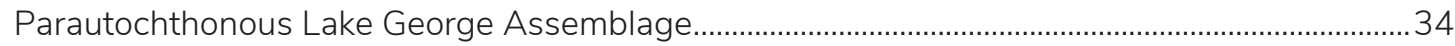

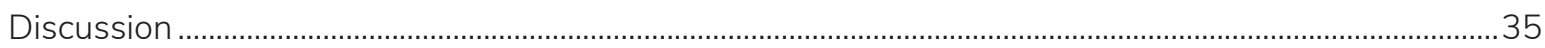

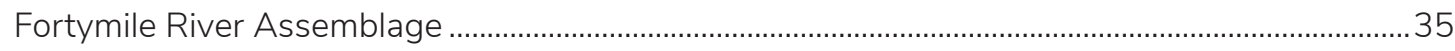

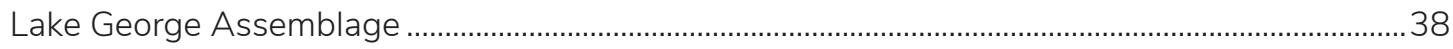

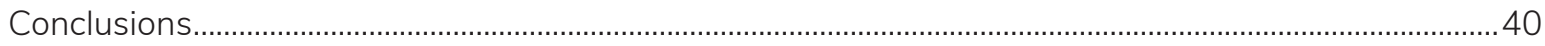

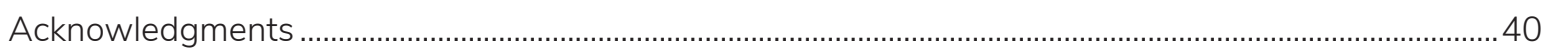

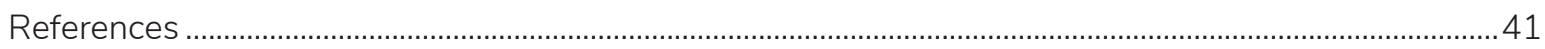

Chapter D: Structural Geology Observations in Northeast Tanacross ...................................................... 43

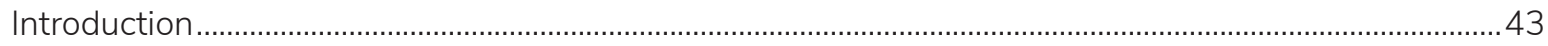

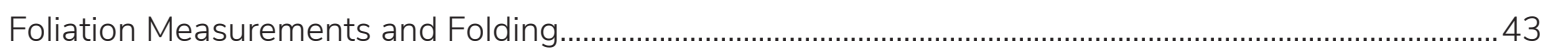

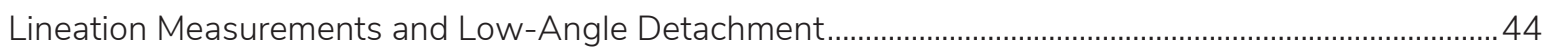

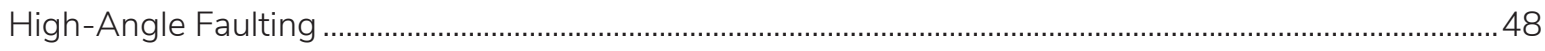

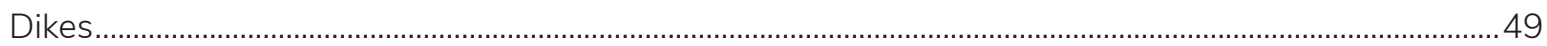

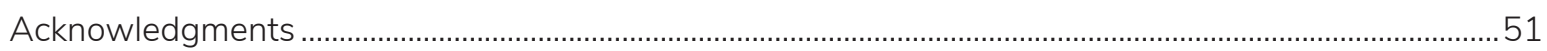

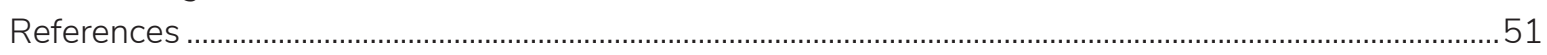

Chapter E: Geochemical Interpretation of Samples of Igneous Rocks from Northeast Tanacross........ 53

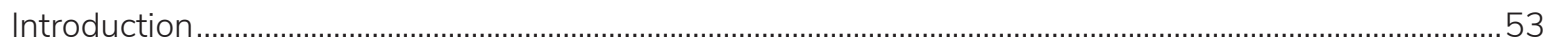

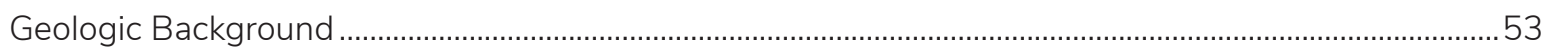

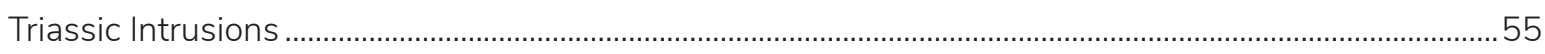

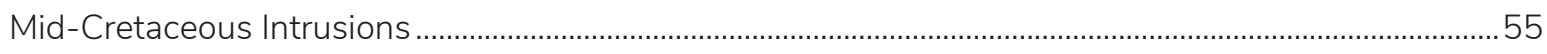

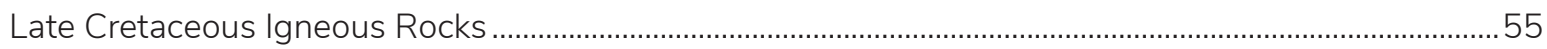

Quaternary Basanites of Prindle Volcano ………..........................................................................................59

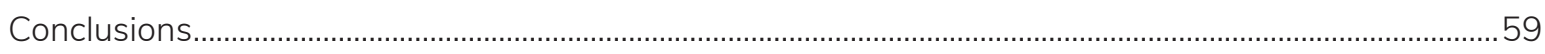

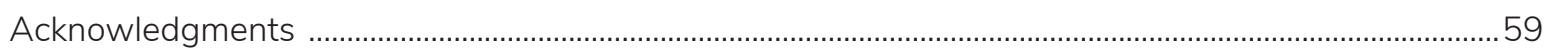

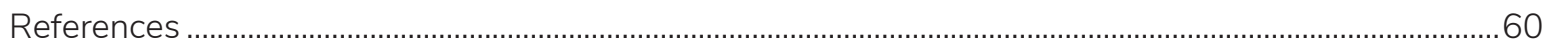

Chapter F: Observations on the Economic Geology of Northeast Tanacross .........................................62

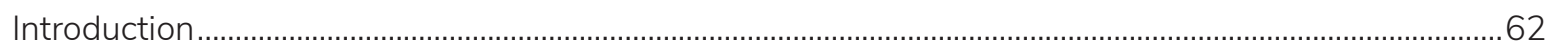

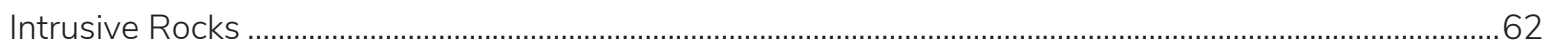

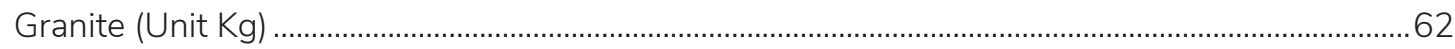

Quartz-Feldspar Porphyry (Unit Kqp) ...................................................................................................... 64 


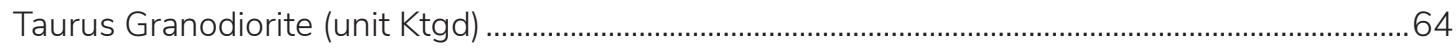

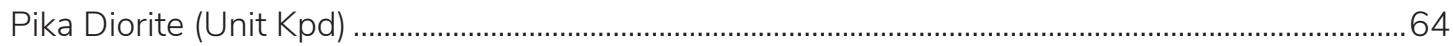

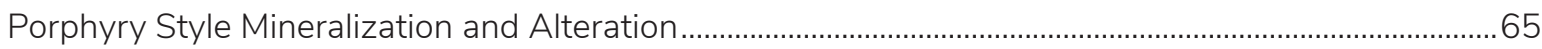

Other Styles of Mineralization and Alteration..............................................................................................65

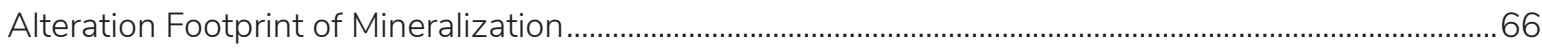

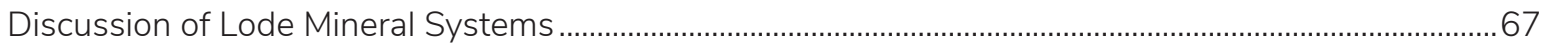

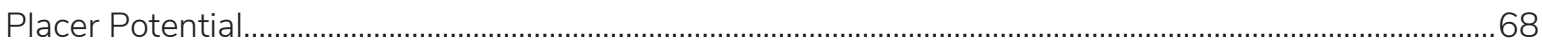

Critical Mineral Potential of the Study Area: Rhenium .................................................................................69

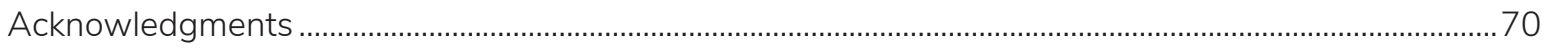

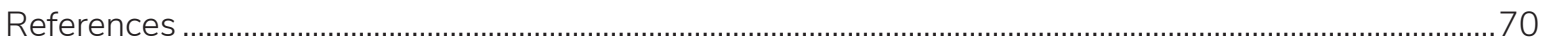

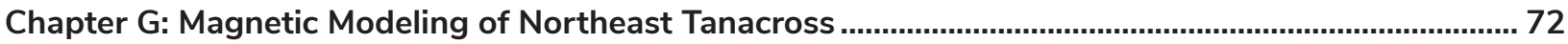

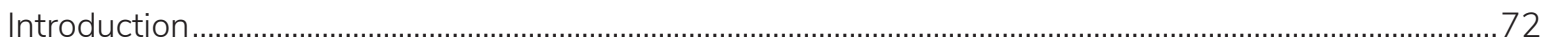

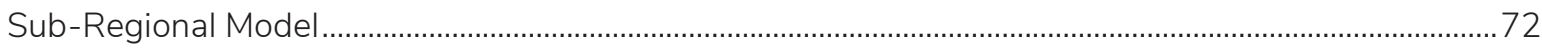

Amphibolite and Serpentinite (MDlau) Unit Models .....................................................................................

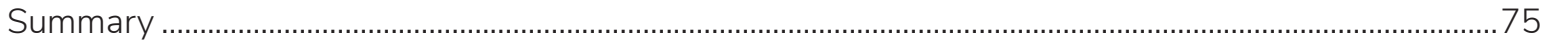

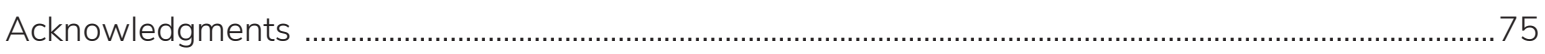

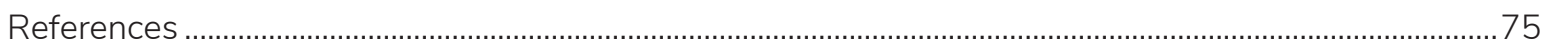




\section{CHAPTER A: INTRODUCTION TO THE NORTHEAST TANACROSS GEOLOGIC MAP}

Alicja Wypych ${ }^{1}$

\section{INTRODUCTION}

The Mineral Resources section of the Alaska Division of Geological \& Geophysical Surveys (DGGS) conducted $500 \mathrm{mi}^{2}$ of 1:63,360-scale geologic mapping in the northeastern Tanacross Quadrangle (Tanacross D-1, and parts of the C-1, C-2, and D-2 quadrangles), located 15 miles southeast of Chicken, Alaska (fig. 1). The project took place during two periods: a reconnaissance mapping effort June 12-22, 2017, and a detailed campaign June 18-July 16, 2018. This map is located within an area of current industry interest; it includes the Taurus porphyry copper-gold-molybdenum \pm rhenium deposit and several other occurrence types including gold, copper, and molybdenum in porphyritic intrusions, structurally controlled silver-lead-zinc prospects, and placer gold deposits (fig. 2). The economic value of the map area is described in detail in chapter F of this report (Twelker and Newberry, 2021), whereas the geochemical properties, similarities, and differences of the intrusive sites are addressed in chapter E (Wypych, 2021).

Prior to DGGS work in the area, the most-detailed mapping was a reconnaissance map at 1:250,000 scale (Foster, 1970). The region also was the focus of a detailed structural study (Hansen and Dusel-Bacon, 1998). In the decades following publication of Foster's map, U.S. and Canadian researchers established a regional geologic and tectonostratigraphic framework (for example, Colpron and others, 2006; Dusel-Bacon and others, 2006) that involves two fundamental components: the allochthonous Yukon-Tanana terrane (YTT) and the parautochthonous North American margin (pNA) from which the YTT initially rifted, and to which it was eventually re-accreted. The boundary between the allochthonous YTT and pNA is one of the fundamental suture zones in the northwestern Cordillera. It has a complex, multiphase structural and metamorphic history (Hansen and Dusel-Bacon, 1998), and the northeastern Tanacross Quadrangle is one of the rare areas in which it is exposed. The conceptual framework has been developed in the literature but it is not fully represented in published geologic maps of eastern Alaska (for example, Wilson and others, 2015). Chapters C and D (Naibert and others, 2021; Naibert, 2021) addresses the newest structural findings as well as detailed mapping of the YTT/ pNA boundary in the area using ${ }^{40} \mathrm{Ar} /{ }^{39} \mathrm{Ar}$ dating techniques in conjunction with field data. Recent detailed studies in the northeastern Tanacross and adjacent area include geophysical surveys (Emond and others, 2015; Burns and others, 2011, 2015; fig. 2). These studies can be used for three-dimensional magnetic modeling of features present under the surface, as shown in chapter G (Emond and Wypych, 2021). The complexity of the geophysical data, ongoing U.S. Geological Survey (USGS) studies (Jones and others, 2017a, 2017b), previous 1:63,360-scale mapping in the Eagle A-1 and A-2 quadrangles immediately to the north (Szumigala and others, 2002; Werdon and others, 2001) and resurgent mineral industry interest in the area prompted DGGS to conduct new 1:63,360-scale geologic mapping in this area (chapter G; map sheet 1 in chapter B).

\section{GEOLOGIC BACKGROUND}

The northeastern Tanacross Quadrangle is characterized by a very complex geologic history, which can be distilled to four main periods. Prior to the Late Devonian the region experienced passive margin deposition equivalent

${ }^{1}$ Alaska Division of Geological \& Geophysical Surveys, 3354 College Rd., Fairbanks, Alaska 99709-3707. 


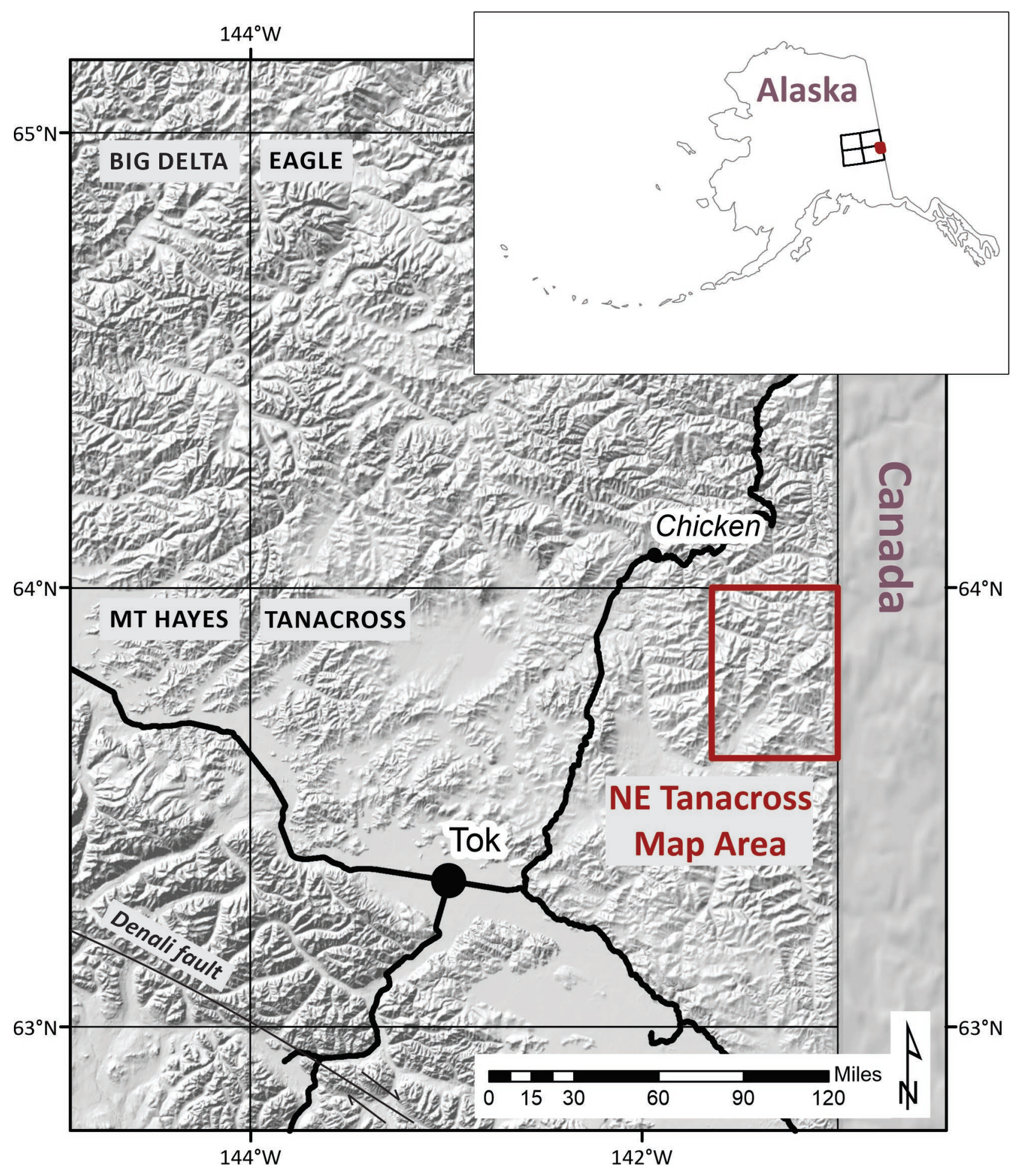

Figure 1. Location of the Northeast Tanacross geologic map area, Tanacross D-1, and parts of the C-1, D-2, and C-2 quadrangles, Alaska. 


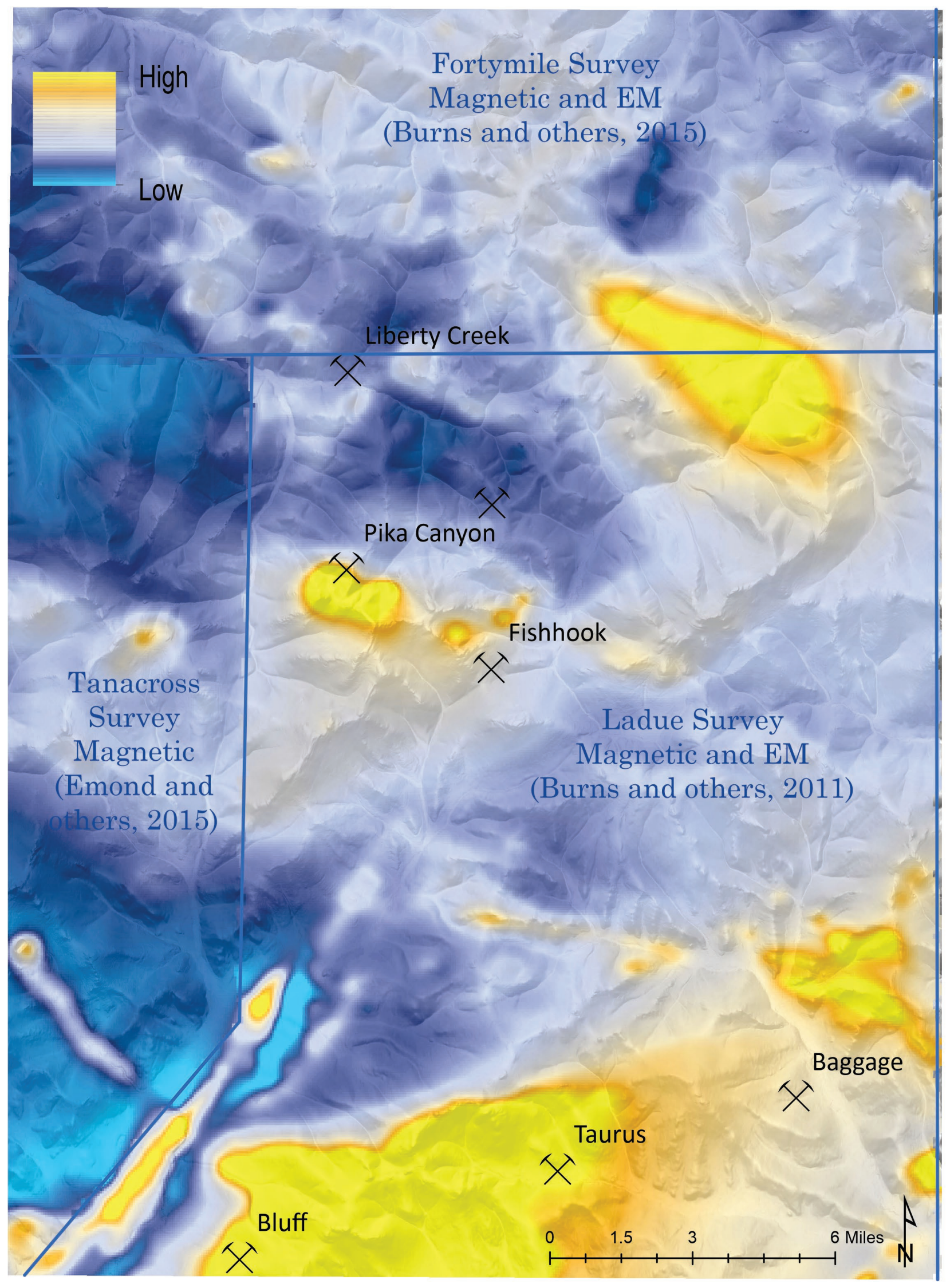

Figure 2. Magnetic surveys overlain on hillshade relief map with location of main prospects in the Northest Tanacross map area. 
to Selwyn basin. In the Late Devonian to Early Mississippian the YTT rifted away from the North American margin, which resulted in a major magmatic episode, emplacing plutons and depositing volcanic rocks, and in the formation of an ocean basin-the Slide Mountain/Seventymile ocean (Dusel-Bacon and others, 2013). From the Mississippian through the Permian, the YTT underwent multiple episodes of arc magmatism while pNA was magmatically quiet. During the Permian the Slide Mountain/Seventymile ocean was consumed by subduction beneath the Klondike arc, and prolonged re-accretion of YTT began (Dusel-Bacon and others, 2013; Beranek and Mortensen, 2011). This resulted in polydeformed metamorphic rocks that underwent regional metamorphism up to amphibolite grade and subsequent exhumation and cooling in the Jurassic to mid-Cretaceous (Hansen and DuselBacon, 1998; Dusel-Bacon and others, 2002). Triassic to Paleogene magmatism variably affected the YTT and pNA as the YTT was re-accreted to form the integrated southern Alaska margin.

Previous 1:250,000-scale reconnaissance mapping of the Tanacross Quadrangle does not address the terranes present; however, it does delineate general amphibolite faces, greenschist faces and carbonaceous Paleozoic units, Tertiary mafic volcanic rocks, Mesozoic granitic rocks, and Paleozoic or Precambrian metamorphic units (Foster, 1970). Coney and others (1980) proposed a "suspect Yukon-Tanana composite terrane" due to the existence of fragments of oceanic arcs and an unknown origin of the metamorphic rocks in this region. The composite Yukon-Tanana terrane concept evolved and was eventually defined as both a parautochthonous continental margin of North America, represented in the southern part of the map area by the Lake George assemblage, and an allochthonous YTT, which is represented by the Fortymile River assemblage in the northern half of the map area (Colpron and others 2006, Dusel-Bacon and others, 2006; Dusel-Bacon and Hansen, 1992).
Lithotectonic units of the allochthonous Yukon-Tanana terrane (locally represented by the Fortymile River and Nasina assemblages; DuselBacon and others, 2017; Szumigala and others, 2002; Werdon and others, 2001) present in the northern part of the Tanacross map area are interpreted as arc and basinal deposits formed on top of, and adjacent to, the rifted YTT during the early Mississippian and thrust over pNA during Permian to Jurassic time (Dusel-Bacon and others, 2006, 2017). Detailed mapping in the Eagle A-1 and A-2 quadrangles revealed the complexity of this terrane immediately north of the field area, and provided a very detailed framework to guide mapping within the Fortymile River assemblage in the northeastern Tanacross Quadrangle (Szumigala and others, 2002; Werdon and others, 2001).

Regionally, metamorphic assemblages of YTT and pNA are intruded by Triassic, Cretaceous, Quaternary, and possibly Neogene volcanic and plutonic rocks. The oldest Mesozoic magmatic body in the region, the Taylor Mountain batholith, is described by Werdon and others (2001) as a multi-phase intrusion with structural fabric present only on the margins of the batholith. This pluton has a complex intrusive history but, based on a titanite $\mathrm{U}-\mathrm{Pb}$ crystallization age, it was emplaced around $214 \mathrm{Ma}$ (Dusel-Bacon and others, 2009). Mid-Cretaceous intrusions include granites such as the ca. $117 \mathrm{Ma}$ Crag Mountain pluton in the Yukon (Yukon Geological Survey, 2019) as well as gabbro, granodiorite, and quartz monzonite ranging in age from ca. 97 to $101 \mathrm{Ma}$ along the Alaska Highway (Solie and others, 2019). Regionally, vein, scarn, and porphyry-style mineralization is often attributed to the mid-Cretaceous intrusions (Allan and others, 2013). Late Cretaceous intrusions include the Mount Fairplay syenite (Foster, 1967), a known rare earth element prospect (Newberry, 2020), and other granodiorite, diorite, monzonite, trachyandesitic porphyries, and andesite bodies in the region, which have a narrow age range between ca. 68 $\mathrm{Ma}$ and ca. $76 \mathrm{Ma}$ (Benowitz and others, 2017). $\mathrm{Cu}-\mathrm{Mo}-\mathrm{Au}$ porphyry mineralization is often associ- 
ated with Late-Cretaceous rocks in the uplands, for example, Taurus porphyry present in the map area (Harrington, 2010). The youngest igneous rocks in the adjacent Eagle A-2 and A-1 quadrangles are gabbro/diabase emplaced ca. $58 \mathrm{Ma}\left({ }^{40} \mathrm{Ar} /{ }^{39} \mathrm{Ar}\right.$ crystallization age; Werdon and others, 2001) and basalt with a ca. $14 \mathrm{Ma}{ }^{40} \mathrm{Ar} /{ }^{39} \mathrm{Ar}$ whole rock age (Szumigala and others, 2002), respectively. Small fault-bounded sedimentary basins were mapped in the Eagle A-1 and A-2 quadrangles (Szumigala and others, 2002; Werdon and others, 2001).

The sedimentary successions consist of conglomerate, sandstone, coal, siltstone, and graywacke, with local felsic tuff, and are Cretaceous to Paleogene (Szumigala and others, 2002; Werdon and others, 2001).

\section{CHAPTERS INCLUDED IN THE REPORT:}

- Chapter A: Introduction to the northeast Tanacross geologic mapping project

- Chapter B: Northeast Tanacross geologic map and map units and descriptions
- Chapter C: Metamorphic cooling history of the Fortymile and Lake George assemblages from ${ }^{40} \mathrm{Ar} /{ }^{39} \mathrm{Ar}$ data from northeast Tanacross

- Chapter D: Structural geology observations in northeast Tanacross

- Chapter E: Geochemical interpretation of samples of igneous rocks from northeast Tanacross

- Chapter F: Observations on the economic geology of northeast Tanacross

- Chapter G: Magnetic modeling of northeast Tanacross

\section{ACKNOWLEDGMENTS}

The DGGS Northeast Tanacross project was funded by the USGS National Cooperative Geologic Mapping Program under STATEMAP award number G18AC00137 for 2018, and by State of Alaska general funds.

We would like to thank James V. Jones III (USGS, Anchorage) and Robert Gillis (DGGS) for thorough and constructive reviews of the geologic map, map unit descriptions, and report. 


\section{REFERENCES}

Allan, M.M., Mortensen, J.K., Hart, C.J.R., Bailey, L.A., Sánchez, M.G., Ciolkiewicz, Witold, McKenzie, G.G., and Creaser, R.A., 2013, Magmatic and metallogenic framework of west-central Yukon and eastern Alaska, in Colpron, Maurice, Bissig, Tomas, Rusk, B.G. and Tompson, J.F.H eds., Tectonics, Metallogeny, and Discovery: Te North American Cordillera and Similar Accretionary Settings, Society of Economic Geologists Inc. Special Publication 17, p. 111-168.

Benowitz, J.A., Sicard, K.R., Naibert, T.J., and Layer, P.W., 2017, ${ }^{40} \mathrm{Ar} /{ }^{39} \mathrm{Ar}$ Age dates from the Tok River area, Tanacross A-5 and A-6 quadrangles and adjoining areas, eastern Alaska Range, Alaska: Alaska Division of Geological \& Geophysical Surveys Raw Data File 2017-5, p. 26 p. doi.org/10.14509/29727

Beranek, L.P., and Mortensen, J.K., 2011, The timing and provenance record of the Late Permian Klondike orogeny in northwestern Canada and arc-continent collision along western North America: Tectonics, v. 30, no. 5, p. 1-23.

Burns, L.E., Geoterrex-Dighem, Stevens Exploration Management Corp., Emond, A.M., and Graham, G.R.C., 2015, Fortymile mining district electromagnetic and magnetic airborne geophysical survey, data compilation: Alaska Division of Geological \& Geophysical Surveys Geophysical Report 2015-4. doi.org/10.14509/29411

Burns, L.E., Fugro Airborne Survey Corp., and Fugro GeoServices Inc., 2011, Ladue survey area: magnetic and electromagnetic line, grid, and vector data and maps, Fortymile mining district, Tanacross Quadrangle, eastern Alaska: Alaska Division of Geological \& Geophysical Surveys Geophysical Report 2011-1, 26 sheets, scale 1:63,360. doi.org/10.14509/22562

Colpron, Maurice, Nelson, J.L., and Murphy, D.C., 2006, A tectonostratigraphic framework for the pericratonic terranes of the northern Canadian Cordillera, in Colpron, Maurice, and Nelson, J.L., eds., Paleozoic evolution and metallogeny of pericratonic terranes at the ancient Pacific margin of North America, Canadian and Alaskan Cor- dillera: Geological Association of Canada Special Paper, v. 45, p. 1-23.

Coney, P.J., Jones, D.L., and Monger, J.W.H., 1980, Cordilleran suspect terranes: Nature, v. 288, p. 329-333.

Dusel-Bacon, Cynthia, Day, W.C., and Aleinikof, J.N., 2013, Geochemistry, petrography, and zircon $\mathrm{U}-\mathrm{Pb}$ geochronology of Paleozoic metaigneous rocks in the Mount Veta area of east-central Alaska: implications for the evolution of the westernmost part of the Yukon-Tanana terrane: Canadian Journal of Earth Sciences, v. 50, no. 8, p. 826-846.

Dusel-Bacon, Cynthia, and Hansen, V.L., 1992, High-pressure amphibolite-facies metamorphism and deformation within the Yukon-Tanana and Taylor Mountain Terranes, eastern Alaska, in Bradley, D.C., and Dusel-Bacon, Cynthia, eds., Geologic studies in Alaska by the U.S. Geological Survey, 1991: U.S. Geological Survey Bulletin 2041, p. 140-159.

Dusel-Bacon, Cynthia, Holm-Denoma, C.S., Jones, J.V. III, Aleinikof, J.N., and Mortensen, J.K., 2017, Detrital zircon geochronology of quartzose metasedimentary rocks from parautochthonous North America, east-central Alaska: Lithosphere, no. 5, p. 1-26.

Dusel-Bacon, Cynthia, Hopkins, M.J., Mortensen, J.K., Dashevsky, S.S., Bressler, J.R., and Day, W.C., 2006, Paleozoic tectonic and metallogenic evolution of the pericratonic rocks of east-central Alaska and adjacent Yukon, in Colpron, Mau-rice and Nelson J.L., eds., Paleozoic Evolution and Metallogeny of Pericratonic Terranes at the Ancient Pacific Margin of North America, Canadian and Alaskan Cordillera: Geological As-sociation of Canada Special Paper 45, p. 25-74.

Dusel-Bacon, Cynthia, Lanphere, M.A., Sharp, W.D., Layer, P.W., and Hansen, V.L., 2002, Mesozoic thermal history and timing of structural events for the Yukon-Tanana Upland, east-central Alaska: ${ }^{40} \mathrm{Ar} /{ }^{39} \mathrm{Ar}$ data from metamorphic and plutonic rocks: Canadian Journal of Earth Sciences, v. 39, no. 6, p. 1,013- 1,051. doi.org/10.1139/e02-018 Dusel-Bacon, Cynthia, Slack, J.F., Aleinikof, J.N., and Mortensen, J.K., 2009, Mesozoic magmatism and base-metal mineralization in the Fortymile 
mining district, eastern Alaska-initial results of petrographic, geochemical, and isotopic studies in the Mount Veta area: Studies by the U.S. Geological Survey in Alaska, 2007: U.S. Geological Survey Professional Paper 1760-A, p. 1-42.

Emond, A.M., Burns, L.E., Graham, G.R.C., and CGG Land (US) Inc., 2015, Tok electromagnetic and magnetic airborne geophysical survey data compilation: Alaska Division of Geological \& Geophysical Surveys Geophysical Report 20152. doi.org/10.14509/29347

Emond, A.M., and Wypych, Alicja, 2021, Chapter G: Magnetic modeling of the northeast Tanacross map area, in Wypych, Alicja, Northeast Tanacross geologic mapping project, Alaska: Alaska Division of Geological \& Geophysical Surveys Report of Investigation 2020-9G. doi.org/10.14509/30558

Foster, H.L., 1967, Geology of the Mount Fairplay area Alaska: U.S. Geological Survey Bulletin 1241B, p. B1-B18.

1970, Reconnaissance geologic map of the Tanacross Quadrangle, Alaska: U.S. Geological Survey Miscellaneous Geologic Investigations Map 593, 1 sheet, scale 1:250,000.

Hansen, V.L., and Dusel-Bacon, Cynthia, 1998, Structural and kinematic evolution of the Yukon-Tanana upland tectonites, east-central Alaska: A record of late Paleozoic to Mesozoic crustal assembly: Bulletin of the Geological Society of America, v. 110, n. 2, p. 211-230.

Harrington, Edward, 2010, Taurus Property: Technical Report for Senator Minerals INC, 133 p. (posted on www.sedar.com).

Jones, J.V. III, Todd, Erin, Caine, J.S., Holm-Denoma, C.S., Ryan, J.J., and Benowitz, J.A., 2017a, Late Permian (ca. 267-257 Ma) magmatism, deformation, and metamorphism and lithotectonic associations of the Ladue River unit in east-central Alaska: Geological Society of America Abstracts with Programs, v. 49, no. 6. doi.org/10.1130/abs/2017AM-304170

Jones, J.V. III, Todd, Erin, Caine, J.S., Holm-Denoma, C.S., Ryan, J.J., Benowitz, J.A., and Drenth, B.J., 2017b, Unraveling the boundary between the Yukon-Tanana terrane and parautochthonous North America in eastern Alaska: Geological So- ciety of America Abstracts with Programs, v. 49, no. 6. doi.org/10.1130/ abs/2017AM-304142

Mortensen, J.K., 1999, Yukon age: An isotopic age database for the Yukon Territory, in Gordey, S.P., and Makepeace, A.J., eds., Yukon digital geology: Exploration and Geological Services Division, Yukon Region, Indian and Northern Affairs Canada.

Naibert, T.J., 2021, Chapter D: Structural geology observations in the northeast Tanacross map area, in Wypych, Alicja, Northeast Tanacross geologic mapping project, Alaska: Alaska Division of Geological \& Geophysical Surveys Report of Investigation 2020-9D. doi.org/10.14509/30541

Naibert, T.J., Wypych, Alicja, and Twelker, Evan, 2021, Chapter C: Metamorphic cooling history of the Fortymile and Lake George assemblages from ${ }^{40} \mathrm{Ar} /{ }^{39} \mathrm{Ar}$ data from the northeast Tanacross Quadrangle, Alaska, in Wypych, Alicja, Northeast Tanacross geologic mapping project, Alaska: Alaska Division of Geological \& Geophysical Surveys Report of Investigation 2020-9C. doi.org/10.14509/30540

Newberry, R.J., 2020, The Mount Fairplay igneous complex: Alaska Division of Geological \& Geophysical Surveys Preliminary Interpretive Report 2020-1, 32 p. https://doi.org/10.14509/30463

Solie, D.N., Werdon, M.B., Freeman, L.K., Newberry, R.J., Szumigala, D.J., Speeter, G.G., and Elliott B.A., 2019, Bedrock-geologic map, Alaska Highway Corridor, Tetlin Junction, Alaska, to Canada Border: Alaska Division of Geological \& Geophysical Surveys Preliminary Interpretative Report 2019-3, 16 p., 2 sheets, scale 1:63,360. doi.org/10.14509/30038

Szumigala, D.J., Newberry, R.J., Werdon, M.B., Athey, J.E., Stevens, D.S.P., Flynn, R.L., Clautice, K.H., and Craw, P.A., 2002, Geologic map of the Eagle A-1 Quadrangle, Fortymile mining district: Alaska Division of Geological \& Geophysical Surveys Preliminary Interpretive Report 2002-1A, 1 sheet, scale 1:63,360. doi. org/10.14509/2863

Twelker, Evan, and Newberry, R.J., 2021, Chapter F: Observations on the economic geology of the northeast Tanacross map area, in Wypych, Alicja, Northeast Tanacross geologic mapping project, Alaska: Alaska Division of Geological \& Geo- 
physical Surveys Report of Investigation 2020-9F. doi.org/10.14509/30557

U.S. Geological Survey, 2008, Alaska resource datafile (ARDF), new and revised records version 1.5.1: U.S. Geological Survey Open-File Report 20081229, 2,243 p.

Werdon, M.B., Newberry, R.J., Szumigala, D.J., and Pinney, D.S., 2001, Geologic map of the Eagle A-2 Quadrangle, Fortymile mining district, Alaska: Alaska Division of Geological \& Geophysical Surveys Preliminary Interpretive Report 2001-3A, 1 sheet, scale 1:63,360, v. 1.0.1. doi.org/10.14509/2669
Wilson, F.H., Hults, C.P., Mull, C.G., and Karl, S.M., 2015, Geologic map of Alaska: U.S. Geological Survey Scientifc Investigations Map 3340, 197 p., 2 sheets, scale 1:1,584,000.

Wypych, Alicja, 2021, Chapter E: Geochemical interpretation of samples of igneous rocks from northeast Tanacross, in Wypych, Alicja, Northeast Tanacross geologic mapping project, Alaska: Alaska Division of Geological \& Geophysical Surveys Report of Investigation 2020-9E. doi.org/10.14509/30542

Yukon Geological Survey, 2019, Yukon Digital Bedrock Geology. www.geology.gov.yk.cal update_yukon_bedrock_geology_map.html [accessed: 3/19/2019] 


\title{
CHAPTER B: NORTHEAST TANACROSS GEOLOGIC MAP AND MAP UNITS AND DESCRIPTIONS
}

\author{
Alicja Wypych ${ }^{1}$, Trent D. Hubbard ${ }^{1}$, Travis J. Naibert ${ }^{1}$, Jennifer E. Athey ${ }^{1}$, Rainer J. Newberry², \\ Karri R. Sicard ${ }^{1}$, Evan Twelker ${ }^{1}$, Melanie B. Werdon ${ }^{1}$, Amanda L. Willingham ${ }^{1}$, W. Chris Wyatt ${ }^{1}$, \\ and Alec C. Lockett ${ }^{3}$
}

\section{DESCRIPTION OF MAP UNITS Quaternary Unconsolidated Deposits}

This map includes unconsolidated surficial deposits in the Tanacross D-1 Quadrangle, the eastern one-third of the Tanacross D-2 Quadrangle, the northern half of the Tanacross B-2 Quadrangle and the northeastern one-third of the Tanacross B-2 Quadrangle (sheet 1). To create this map we incorporated (1) geologic information from previous geologic mapping and published literature, (2) new interpretations using remotely sensed imagery, and (3) information gathered from limited field investigations. Previous geologic mapping of the unconsolidated deposits in the Tanacross Quadrangle includes work by Foster (1970) at a scale of 1:250,000, which provided a framework for our mapping and was instrumental in understanding the regional distribution and character of Quaternary deposits. Weber (1986) described the glacial history of the Yukon Tanana Upland and gave detailed descriptions of the extent and character of these deposits. Her work along with glacial limits mapped by Péwé and others (1967) helped us identify and map glacial deposits in the map area. Work by Pinney (2001) and Stevens and Burns (2010) in the Eagle A-1 and A-2 quadrangles enabled us to understand the distribution and character of deposits in adjoining areas to the north and enhanced our understanding of the morphology and distribution of alluvial terraces, many of which are gold bearing and extend southward into this map area. Mapping at a scale of 1:50,000 in the adjoining Borden Creek and Crag Mountain quadrangles by Jackson (2005a, 2005b) allowed comparisons with the distribution and character of deposits in Canada.

\section{Remotely Sensed Imagery}

Surficial geology was mapped by interpreting 2.5-m-resolution SPOT 5 color-infrared and natural color red-green-blue (RGB) imagery (C2013, Distribution SpotImage S.A., SICORP, USA, all rights reserved) collected in 2009 and 2010 and stereoscopic pairs of approximately 1:65,000-scale, false-color, infrared aerial photographs taken in 1978 and 1981. SPOT 5 imagery was interpreted in ArcGIS Pro by overlaying it on hillshade and slopeshade images derived from Interferometric Synthetic Aperture Radar (IFSAR) bare-earth digital-elevation models (DEMs) created using data collected in 2010. By using the pseudo-3-D functionality of ArcGIS Pro and adjusting the transparency of the SPOT 5 imagery and the transparency and color of hillshade and slopeshade images, we were able to visualize subtle differences in features and identify geologic landforms. We used aerial photographs to identify geologic features and check our interpretations. Geospatial polygon features that represent geologic units were drawn using onscreen digitizing techniques in ArcGIS Pro.

\section{Field Work}

We conducted helicopter-supported surficial geology field work June 20-23, 2017, and July 3-4, 2018. During the field campaign we visited exposures and dug soil pits to examine material and gather information for unit descriptions and to check geologic mapping. We also measured the thickness of the active layer at several locations.

${ }^{1}$ Alaska Division of Geological \& Geophysical Surveys, 3354 College Rd., Fairbanks, Alaska 99709-3707.

${ }^{2}$ Department of Geosciences, University of Alaska, P.O. Box 755780, Fairbanks, Alaska 99775-5780

${ }^{3}$ Colorado College, Department of Geology, 14 East Cachel la Poudre St., Colorado Springs, Colorado 80903 


\section{Man-made deposits}

PLACER-MINE TAILINGS AND ARTIFICIAL FILLS (QUATERNARY)—Pebble-cobble gravel with trace to some sand and silt forming tailings piles. Well to poorly sorted. Surface smooth to irregular.

\section{Alluvial deposits}

Qa

Qaf

Qfp

Qat3

Qat2

Qat1
ALLUVIUM OF MODERN STREAM CHANNELS (QUATERNARY)—Stratified, well-sorted to locally poorly sorted, rounded to subangular, polymictic pebble-cobble gravel, sand, and silt. Includes sediments deposited in active stream channels, floodplains, and associated low terraces that cannot be differentiated at the scale of mapping. Frequency and timing of deposition is uncertain. In areas where inundation is infrequent, deposits may be locally overlain by ice-rich organic silt. Vegetation includes alders, willows, and scattered spruce that are more dense along (but not in) active stream channels where stream inundation is more frequent and the active layer is thicker.

ALLUVIAL-FAN DEPOSITS (QUATERNARY)_Fan-shaped deposits of stratified, well- to poorly sorted gravel, sand, and silt with scattered pebbles and cobbles. Debris-flow deposits are common in upper (proximal) zones of fans. Clast size decreases and degree of sorting increases distally from the head of the fan. Deposits are found along the margins of larger valleys at the mouths of tributary streams and gullies, where they are often associated with complex colluvial and alluvial valley-fill deposits (Qca), and older terrace alluvium (Qat1 and Qat2).

FLOODPLAIN ALLUVIUM (QUATERNARY)—Elongate deposits of well-sorted to locally poorly sorted, rounded to subangular, polymictic, pebble-cobble gravel, sand, and silt in floodplains and associated low terraces. Lower surfaces may be flooded during times of maximum stream discharge.

YOUNG TERRACE ALLUVIUM (QUATERNARY)_Elongate deposits of well-sorted to locally poorly sorted, rounded to subangular, polymictic pebble-cobble gravel and sand with trace to some silt overlain by ice-rich organic silt and overbank deposits. Deposits form low terraces approximately $10-15 \mathrm{~m}$ above modern streams.

OLD TERRACE ALLUVIUM (QUATERNARY) —Elongate deposits of well-sorted to locally poorly sorted, rounded to subangular, polymictic pebble-cobble gravel, sand, and silt capped by variable thicknesses of ice-rich primary and reworked eolian silt. Vegetation generally consists of tussock tundra with scattered to sparse and often stunted black spruce.

Most deposits are present as benched surfaces along valley margins that are 30-40 m above modern stream channels. Surfaces are moderate to gently sloping parallel to stream channels and have typically been extensively modified by slope processes, such as gelifluction and solifluction. Based on their mapping in the Eagle A-1 and A-2 quadrangles directly north of the map area, Stevens and Burns (2010) and Pinney (2001) suggested these terrace deposits are not related to modern drainage and may be Pleistocene in age as current streams do not appear to be capable of depositing such material. Based on our observations including the degree of surface modification from slope processes, we agree with this assertion although we were unable to date these surfaces.

OLDEST TERRACE ALLUVIUM (QUATERNARY)_Elongate deposits of well-sorted to locally poorly sorted, rounded to subangular, polymictic, pebble-cobble gravel, sand, and silt. 
Vegetation generally consists of tussock tundra with scattered to sparse and often stunted black spruce that are often tilted as a result of complex, frost-action processes.

Deposits occur on benched surfaces along valley margins that are up to approximately $125 \mathrm{~m}$ above the modern stream channels. Surfaces are moderately sloping parallel to stream channels and have been extensively modified by slope processes that include gelifluction and solifluction. Primary morphology has generally been destroyed and deposits are often discontinuous. Oldest terrace surfaces are often adjoined by colluvium $\left(\mathrm{Qc}_{\mathrm{c}}\right.$ ) and mixed colluvial and alluvial valley fill deposits (Qca) that are present on steeper slopes and valley sidewalls. Open-system pingos are often found at these unit boundaries.

The oldest terrace surfaces are most common along valley side slopes in larger stream valleys within the map area. The proximity of the oldest terrace deposits to older cirques with subdued morphology in high-elevation source areas indicates that these deposits are of glaciofluvial origin.

\section{Colluvial deposits}

Qc

Qcf

Qcl

Qcr

Qca

UNDIFFERENTIATED COLLUVIUM (QUATERNARY)_Blankets, aprons, cones, and fans of heterogeneous, angular to subangular rock fragments, gravel, sand, and silt formed by residual weathering and complex, gravity-driven mass movements involving rolling, sliding, flowing, solifluction (or gelifluction where frozen), and frost action on weathered bedrock and unconsolidated deposits. Deposits are generally unsorted to poorly sorted. Thickness is highly variable, often reflecting the configuration of bedrock where thin and forming thick deposits at the base of slopes.

Unit includes Quaternary deposits whose origins are uncertain or whose primary depositional morphology was modified or destroyed by weathering and slope processes. May be complexly mixed with terrace deposits (Qat1, Qat2, and Qat3), glacial drift (Qgd), and complex colluvial and alluvial deposits (Qca).

FINE-GRAINED COLLUVIUM AND SILT (QUATERNARY)_Deposits of fine-grained colluvium and silt. Silt is largely retransported from original hillside sites to lower slopes by a variety of complex slope processes. Deposits are commonly perennially frozen and ice rich.

COLLUVIAL LANDSLIDE DEPOSITS (QUATERNARY)_Elongate to lobate mixtures of bedrock blocks, angular to subangular rock fragments, and polymictic gravel, sand, and silt deposited on steep slopes by sliding of failed bedrock and unconsolidated surface deposits. Surfaces modified by creep and flow.

or RUBBLE DEPOSITS (QUATERNARY)—Heterogeneous mixtures of frost-rived, angular, blocky rock fragments with trace to some gravel, sand, and silt deposited by free fall, tumbling, rolling, and sliding. Most commonly found on steep bedrock slopes and downslope of bedrock outcrops, and undifferentiated colluvium (Qc).

\section{Complex deposits}

COLLUVIAL AND ALLUVIAL VALLEY-FILL (QUATERNARY)—Massive to poorly stratified sand and silt mixed with subangular to rounded pebble-cobble gravel and locally derived bedrock clasts deposited in upper stream courses and on lower slopes along the margins of stream valleys by complex mass-movement processes (including rolling, sliding, flowing, gelifluction, and frost action). Locally may include debris flow deposits. Deposits are locally overlain by variable thickness of ice-rich organic silt that, when exposed, undergoes active thermokarst degrada- 
tion. Surface commonly has numerous trees that are leaning as a result of frost action. Complexly mixed with colluvium (Qc), older alluvial deposits (Qat1, Qat2), and glacial drift (Qgd).

These types of deposits are present where (1) streams are not able to remove material faster than it is transported by downslope by colluvial processes, or (2) where material originally deposited by stream processes has been reworked by complex slope processes destroying the original morphology.

\section{Glacial deposits}

Qgd UNDIFFERENTIATED GLACIAL DRIFT (QUATERNARY)—Heterogeneous mixtures of poorly to moderately sorted, subangular to rounded boulders, gravel, sand, and silt deposited by ancient alpine glaciers and then extensively modified by slope processes. Preserved as irregular patches of thin drift within colluvial deposits (Qc). Structure of underlying bedrock typically visible.

Associated valley headwalls in the highest elevations exhibit subdued, cirque-like morphology. Valley cross-profiles are highly modified by the accumulation of colluvium on valley walls and by stream erosion. Streams are markedly underfit for the valleys they occupy.

Based on characteristics such as subdued morphology, elevation of source areas, and apparent extreme age, the mapped deposits could correlate with early Pleistocene glacial deposits of the Charley River glaciation described by Weber (1986) in the Yukon Tanana Upland, Weber and Wilson (2012) in the Eagle Quadrangle, and cirques of the pre-Reid glaciation mapped by Jackson (2005a, 2005b) in Canada just east of the map area.

\section{BEDROCK GEOLOGIC UNITS Sedimentary rocks}

CONGLOMERATE AND SANDSTONE (LATE CRETACEOUS)—Lithified conglomerate, sandstone, claystone, and poorly lithified gravel, sand, silt, and clay. Beds are rarely graded. Sandstones are typically medium grained. Conglomerates are clast-supported to matrix-supported, are poorly- to well-sorted, and include pebbles, cobbles, and rare boulders up to $50 \mathrm{~cm}$ in diameter. Subangular to rounded clasts of semischist, augen gneiss, volcanic rocks, vein quartz, chert, paragneiss, greenschist, and graphitic quartzite are hosted in either a pale-green clay-rich matrix or quartz-rich matrix. The field relationship between this conglomerate and the volcanic rocks (unit $\mathrm{Kv}$ ) in the vicinity of VABM Lode suggests the conglomerate was deposited before the volcanic rocks, requiring this unit to be Late Cretaceous or older. The unit is up to $150 \mathrm{~m}$ thick. No direct contact was observed. Two samples, a sandstone and a conglomerate, yielded youngest detrital zircon age populations of $106.1 \pm 0.9 \mathrm{Ma}$ and $105.5 \pm 5.6 \mathrm{Ma}$, respectively, indicating a Cretaceous depositional age (on 4 grains; Wypych and others, 2020). Foster and Igarashi (1990) found pollen assemblages indicating that both Late Cretaceous and Miocene or younger sedimentary rocks comprise a belt extending westward from the westernmost exposure of unit Kc in the map area. Similar conglomerate in the Eagle A-1 and A-2 quadrangles (Szumigala and others, 2002; Werdon and others, 2001), elsewhere in the northern Tanacross Quadrangle, and to the east in Canada (Yukon Geological Survey, 2019) were likely deposited in Late Cretaceous, Miocene or later based on pollen ages (Foster and Igarashi, 1990).

\section{Igneous rocks}

Qb PRINDLE VOLCANO BASANITE (QUATERNARY)—Cinder cone deposits, flows, and dikes of basanite, trachyandesite, and alkali-basalt. The cinder cone at Prindle Volcano in the Tanacross 
C-2 Quadrangle consists of interlayered spatter and flow deposits. A composite lava flow extends 8 miles $(12.9 \mathrm{~km})$ to the southeast from the vent site. Spatially limited flows and dikes of the same composition are locally present throughout the map area. Dark-gray, brown-weathering, vesicular flows contain abundant xenoliths of peridotite, tonalite, and metamorphic rocks. Mafic lavas are composed of aphanitic, weathered volcanic glass with about 7 percent phenocrysts, which include subhedral to anhedral olivine, and 3 percent subhedral to euhedral pigeonite. Olivine phenocrysts form two distinct populations: one larger fraction (up to $2 \mathrm{~mm}$ in diameter), which is often resorbed on the rims, and a smaller (about $0.3 \mathrm{~mm}$ in diameter) anhedral fraction. Pigeonite crystals are up to $0.2 \mathrm{~mm}$ in diameter, with rare augite lamellae. Unit is magnetic, with magnetic susceptibility ranging from 1.7 to $18.4 \times 10^{-3}$ Système International (SI). Cinder cone basanite yielded whole rock ${ }^{40} \mathrm{Ar} /{ }^{39} \mathrm{Ar}$ plateau age of $200,000 \pm 60,000$ years and an age of $176,000 \pm 16,000$ years using the (U-Th)/He method on zircon (Andronikov and Mukasa, 2010; Blondes and others, 2007).

VOLCANIC FLOWS, DIKES, AND PLUGS (LATE CRETACEOUS)_Basaltic andesite and andesite with rare dacite to rhyolite flows; gray, pale green, to dark maroon or gray, weathers orange, tan, or brown. Flows are porphyritic, with aphanitic groundmass, and are autobrecciated at flow edges. Phenocryst size ranges from 0.01 to $7 \mathrm{~mm}$. Mineralogy includes $10-30$ percent plagioclase laths, 5 percent hornblende, 1 percent quartz, less than 1 percent biotite, some disseminated magnetite, and rare pyrite. Large hornblende phenocrysts (up to $8 \mathrm{~mm}$ in length) and partially clay-altered plagioclase laths (up to $2 \mathrm{~cm}$ in length) occur in a gray groundmass. Plagioclase phenocrysts are subhedral, with polysynthetic twinning, some sericitization, and rounded and altered rims. Euhedral hornblende phenocrysts are smaller, $1 \mathrm{~mm}$ long on average, but up to $8 \mathrm{~mm}$, with inclusions of opaque minerals and quartz(?). Quartz phenocrysts are rare, subhedral, $2 \mathrm{~mm}$ long, and rounded and resorbed on the edges. Rare, medium-grained, subhedral biotite phenocrysts are elongate and often have resorbed edges. The groundmass is recrystallized to a mixture of fine-grained feldspar \pm quartz and opaque minerals, with spheroidal chlorite. Weathering is fracture controlled. The volcanic flows are generally thin; however, in the central Tanacross D-1 Quadrangle they reach a thickness of around $150 \mathrm{~m}$. Base on the presence of andesite in drill hole BL11-004 and magnetic properties of the rock underlying the East Fork of the Dennison River, we infer about $38 \mathrm{~km}^{2}$ of the volcanic flow to be present there. Magnetic susceptibility varies with alteration. In altered rocks it is as low as $0.1 \times 10^{-3} \mathrm{SI}$, and in unaltered outcrops the magnetic susceptibility reaches $55 \times 10^{-3} \mathrm{SI}$ and averages $18-20 \times 10^{-3} \mathrm{SI}$. A dacite whole rock analysis yielded an ${ }^{40} \mathrm{Ar} /{ }^{39} \mathrm{Ar}$ plateau age of 65.5 $\pm 0.4 \mathrm{Ma}$ (Naibert and others, 2018) and two samples of andesites yielded U-Pb zircon crystallization ages of $67.7 \pm 0.9 \mathrm{Ma}$ and $71.5 \pm 3.0 \mathrm{Ma}$ (Todd and others, 2019).

Kpd PIKA DIORITE (LATE CRETACEOUS)—Dikes, plugs, and intrusions of diorite to granodiorite in general vicinity of the Pika and Fishhook prospects. Gray, tan, green-gray, or light brown, and weathers orange-tan. Texture is massive, porphyritic, seriate, or equigranular. Porphyritic phases consist of 5-30 percent plagioclase, $1-15$ percent hornblende, and $2-10$ percent biotite phenocrysts in a gray aphanitic groundmass. Hornblende phenocrysts are up to $8 \mathrm{~mm}$ long, and partially clay-altered plagioclase laths are up to $2 \mathrm{~cm}$ in length. Rare euhedral biotite is medium grained. Equigranular to seriate phases consist of up to 85 percent plagioclase crystals between 0.5 and $5 \mathrm{~mm}$ in length, up to 20 percent quartz, up to 15 percent pyroxene, 5-14 percent biotite, about 2 percent hornblende, up to 5 percent magnetite, and rare epidote. Some propylitic alteration and chloritization is present. This unit is very magnetic - the average mag- 
netic susceptibility is $20 \times 10^{-3} \mathrm{SI}$, but it ranges between 2 and $45 \times 10^{-3} \mathrm{SI}$. Biotite from diorite yielded ${ }^{40} \mathrm{Ar} /{ }^{39} \mathrm{Ar}$ plateau age of $66.3 \pm 0.7 \mathrm{Ma}$ (diorite; Naibert and others, 2018) and a zircon $\mathrm{U}-\mathrm{Pb}$ age of $70.3 \pm 0.5$ (diorite porphyry; Todd and others, 2019).

TAURUS GRANODIORITE (LATE CRETACEOUS)_Dikes and intrusions of granodiorite with lesser quartz monzonite and porphyries of andesitic to dacitic composition located in the Taurus prospect area. Gray, pinkish gray, pink-green, or pale green; weathers orange or pale brown. Outcrops are massive and jointed. Porphyritic phases have a grain size between 0.01 and $10 \mathrm{~mm}$. Contains up to 75 percent feldspar, 15 percent hornblende phenocrysts, and up to 7 percent clinopyroxene in fine-grained or aphanitic matrix. Minor biotite and quartz are sometimes present but generally do not exceed 1 percent. Feldspar and quartz look fresh and are between 2 and $5 \mathrm{~mm}$. Hornblende is chloritized, often has biotite cores, and ranges from 3 to $7 \mathrm{~mm}$ in length. Sulfides can be disseminated through the rock. In the porphyry end-member, groundmass forms up to 94 percent of the rock. This porphyry is locally altered to a sericite-tourmaline assemblage carrying elevated silver values (Wypych and others, 2017, 2018). Unaltered samples have high magnetic susceptibility values ranging from 0 to $52 \times 10^{-3}$ $\mathrm{SI}$, averaging $8 \times 10^{-3} \mathrm{SI}$. The granodiorite has been dated using $\mathrm{U}-\mathrm{Pb}$ to be $71.0 \pm 1.1 \mathrm{Ma}$ ( $\mathrm{Wy}-$ pych and others, 2020).

Kqp QUARTZ-FELDSPAR PORPHYRY (LATE CRETACEOUS)_Dikes and small intrusive bodies of porphyry with trachyandesite to monzodiorite composition, located in the Taurus and Bluff prospects. Tan, pale gray to pale green, pale pink, jointed, porphyritic to equigranular, with grain sizes between 0.01 and $8 \mathrm{~mm}$. The porphyritic rocks are more common, and an aphanitic matrix. Equigranular phases have up to 30 percent quartz, 20 percent biotite, up to 3 percent hornblende, and 75 percent feldspar. Both phases are highly altered with potassic as well as quartz-sericite-pyrite alteration and are cut by molybdenite-pyrite veins. Altered rocks have elevated gold and molybdenum (Wypych and others, 2017; Wypych and others, 2018) and low magnetic susceptibility averaging about $1 \times 10^{-3} \mathrm{SI}$. The porphyry phase has a U-Pb age of 70.6 $\pm 0.9 \mathrm{Ma}$ (Todd and others, 2019).

$\mathrm{Kfg}_{\nu}>$ FRED GRANITE (CRETACEOUS?) —Medium-grained, biotite-bearing granite to quartz-syenite occurring as small stocks in the vicinity of VABM Fred. Pink to gray, jointed, porphyritic to equigranular, and hypidiomorphic; grain size ranges from 1 to $6 \mathrm{~mm}$. Mineralogy includes up to 45 percent euhedral potassium feldspar, up to 25 percent subhedral quartz, 20-25 percent plagioclase, and up to 15 percent biotite. Potassium feldspar phenocrysts are up to $6 \mathrm{~mm}$ in length and are hosted in a finer-grained matrix of plagioclase, quartz, and biotite. In the outcrop scale, the granite locally contains inclusions of metamorphic material and has similar trace-element lithogeochemistry as the intrusive rocks in the map area (unit $\mathrm{Kg}$ ); therefore, it is most likely of mid-Cretaceous age. The magnetic susceptibility is very low, ranging from 0.05 to $0.21 \times 10^{-3} \mathrm{SI}$.

GRANITE (CRETACEOUS)_Garnet-bearing granite and biotite-bearing granite stocks and intrusions, with aplite and pegmatite dikes of similar composition. Granite is tan, cream, or light gray to pale pink, seriate to equigranular, hypidiomorphic, with grain size between 0.1 and 35 $\mathrm{mm}$. Typically the granite has up to up to 40 percent potassium feldspar, 30 percent plagioclase, 30 percent quartz, 3 percent white mica, 3 percent biotite, and locally 1 percent garnet. Locally altered to clay and chlorite, but is generally fresh with rare veins of pyrite. Weak foliation is locally observed, generally near intrusion edges. 
Pegmatite dikes are similar in composition to the granite, with up to $50 \mathrm{~mm}$ long euhedral orthoclase and microcline crystals in a matrix of about $10 \mathrm{~mm}$ diameter quartz and plagioclase. Thin books of biotite between 50 and $70 \mathrm{~mm}$ long are found irregularly throughout the rock. Biotite is slightly chloritized on margins, and forms up to 5 percent of the rock.

Aplite dikes are light gray and equigranular, with grain sizes between 0.5 and $2 \mathrm{~mm}$. Mineralogy is similar to larger granitic intrusions, and includes rare metamorphic xenoliths. Locally altered with up to 1 percent disseminated pyrite, sparse quartz veinlets, sericite, and local tourmaline clots (up to 0.1 percent).

The granites, pegmatites, and aplites are characterized by low magnetic susceptibility, ranging between 0 and 1.5 and averaging $0.3 \times 10^{-3} \mathrm{SI}$. Granite and pegmatite ${ }^{40} \mathrm{Ar} /{ }^{39} \mathrm{Ar}$ ages in the map area range from ca. 105 to $110 \mathrm{Ma}$ (Naibert and others, 2018), and a granite zircon U-Pb age is $114.1 \pm 1.4 \mathrm{Ma}$ (Wypych and others, 2020). On the eastern edge of the Tanacross D-1 Quadrangle, the granite extends into Yukon, Canada, where it is mapped as the ca. 110-109 Ma Crag Mountain pluton, which is part of the Whitehorse Plutonic Suite (Yukon Geological Survey, 2019). The granite has similar age and composition to other granites in the Yukon such as the Dawson Range batholith, the Coffee Creek granite, and the Moosehorn Range granitoids (Allan and others, 2013).

Ktp TIMBER GRANITE (CRETACEOUS)_Biotite-bearing granite intrusion forming the bulk of Timber Mountain in the Tanacross C-1 Quadrangle. Gray to dark gray and weathers tan, pink or gray. Massive, equigranular to porphyritic, and hypidiomorphic; grain size ranges from 0.2 to $15 \mathrm{~mm}$. Composed of 45-70 percent feldspar, 20-40 percent quartz, up to 15 percent biotite, and up to 10 percent muscovite. Fine-grained equigranular phases are found on the edges of the intrusion whereas porphyritic and medium-grained equigranular phases are typically observed towards the center. Porphyritic phases have up to 10 percent, 15-mm-long feldspar phenocrysts in a fine-grained quartz-feldspar-biotite matrix. The fine-grained equigranular phase is composed of near equal amounts of quartz, potassium feldspar, and plagioclase, with 2 percent biotite and 1 percent muscovite. The intrusion is weathered, chloritized, and partially replaced by opaque minerals, biotite, and slightly sericitized plagioclase. The medium-grained equigranular phases generally are unaltered. In both equigranular phases, quartz is anhedral, interstitial, and generally inclusion free. Potassium feldspar is anhedral to euhedral, with no twinning or microcline twinning, faint zonation, and rare perthitic exsolution textures. Plagioclase is subhedral to euhedral, with clear polysynthetic twinning, slight sericitization, and myrmekite exsolution textures. The pluton is non-magnetic, with magnetic susceptibility ranging from 0.006 to 0.564 x $10^{-3}$ SI. Biotite from this pluton yielded a K-Ar age of ca. $108 \mathrm{Ma}$ (Foster and others, 1976) and zircon yielded a U-Pb age of $110.3 \pm 1.4 \mathrm{Ma}$ (Wypych and others, 2020).

kwp WITHERSPOON FELDSPAR PORPHYRY (LATE TRIASSIC)—Granite to diorite dikes, plugs, sills, and intrusions. Green, dark green, dark gray, or pink-gray, and weathers to maroon. Typically, porphyritic, with phenocrysts ranging from 0.1 to $15 \mathrm{~mm}$. Composed of up to 72 percent feldspar, about 30 percent amphibole, 20 percent quartz, and 10-25 percent biotite with disseminated iron oxides. Abundant feldspar phenocrysts, up to $15 \mathrm{~mm}$ long, occur in a dark green groundmass with extensive secondary chlorite and some epidote replacement of plagioclase. Possible weak magmatic or metamorphic fabric and chloritic alteration were observed locally. The unit is non-magnetic to weakly magnetic, with magnetic susceptibility ranging from 
0.089 to $0.528 \times 10^{-3} \mathrm{SI}$. Two samples, a porphyry and a granite, yielded zircon U-Pb ages of $203.7 \pm 1.6$ and $206.2 \pm 2.6 \mathrm{Ma}$ (Wypych and others, 2020). Based on the ages and mineral composition and textures observed in the field, this pluton can be assigned to Taylor Mountain Batholith suite (Werdon and others, 2001).

\section{METAMORPHIC ROCKS (GREENSCHIST TO EPIDOTE-AMPHIBOLITE FACIES) Meta-mafic rocks}

kPzum SERPENTINIZED ULTRAMAFIC ROCKS (TRIASSIC TO PALEOZOIC)_Fine-grained serpentinite with local relict olivine. Occurs along the thrust fault between Nasina and Fortymile River assemblages. As described by Flynn (2003), unit is typically green to dark gray, unfoliated, and weathers orange-brown. Typically consists of a matrix of fine-grained serpentine, up to 20 percent relict olivine, and 5-10 percent disseminated magnetite and magnetite veins. Serpentine is antigorite, with scarce chrysotile near contacts. Locally altered to coarse-grained chlorite rock. Ultramafic rocks appear to be serpentinized dunite metamorphosed to greenschist facies. Magnetic susceptibility of the serpentinized ultramafic rocks generally is very high; typically, 10-60 x 10 $0^{-3}$ SI. Waxy massive serpentinite with relatively low magnetic susceptibility, between 0.1 and $1 \times 10^{-3} \mathrm{SI}$, is present near some contacts. This unit is a continuation of the greenschist-facies serpentinite (unit MzPzs) mapped in the southeastern Eagle A-1 Quadrangle (Szumigala and others, 2002) and across the border in Yukon (Yukon Geological Survey, 2019); both maps correlate these rocks to the Seventymile terrane (Slide Mountain terrane of the Yukon). At Clinton Creek, Yukon, these mafic and ultramafic rocks are interlayered with sedimentary rocks that yielded a Triassic conodont age (Abbott, 1983), likely the minimum age for this unit. The maximum age may be constrained by the opening of the Seventymile/Slide Mountain ocean in the Devonian to Mississippian (Dusel-Bacon and others, 2006).

\section{Allochthonous rocks of Klondike assemblage}

The Klondike assemblage is suspected to be present in the southeastern corner the map area adjacent to the Alaska-Yukon border. The contact of the Klondike assemblage units with other allochthonous Yukon Tanana terrane units is interpreted as one or more low-angle. The Klondike units are also in low-angle fault contact with the parautochthonous Lake George assemblage. The assemblage is mapped across the border in Yukon, where it rests unconformably over Snowcap assemblage metasediments and is intruded by coeval Permian orthogneisses of the Sulphur Creek plutonic suite. Unit description for the Klondike assemblage schist is from Twelker and others (2021).

Pks? SCHIST (PERMIAN) — A unit consisting primarily of chlorite schist, muscovite schist, and semischist with mixed sedimentary and felsic volcanic protoliths. The unit also contains minor quartzite and porphyroclastic orthogneiss and rare conglomerate. Outcrops are generally pale green to dark green to gray and grain size ranges from 0.1 to $10 \mathrm{~mm}$. Rare conglomerates have clasts up to $60 \mathrm{~mm}$. The unit is schistose and the dominant foliation is often folded at the decimeter to meter scale and also crenulated on the sub-cm scale. Schistose texture and mineralogy indicate the unit reached greenschist-facies metamorphic conditions. Mineralogy includes 3060 percent quartz, up to 40 percent actinolite, up to 40 percent plagioclase feldspar, up to 15 percent muscovite, up to 15 percent biotite, up to 10 percent chlorite, up to 5 percent epidote, and traces of pyrite. Schists are locally iron stained and contain traces of pyrite along fracture 
surfaces and veinlets. Magnetic susceptibility ranges from a minimum of $0.04 \times 10^{-3} \mathrm{SI}$ units to a maximum of $2.91 \times 10^{-3}$ SI units, with an average of $0.89 \times 10^{-3}$ SI units and a median of $0.23 \times 10^{-3} \mathrm{SI}$ units. U-Pb ages between 257 and $267 \mathrm{Ma}$ (Jones, personal commun., 2020) were recorded from four metavolcanic schist samples in the map area and support correlation to the mapped Klondike Schist units in Yukon.

\section{Allochthonous rocks of Nasina assemblage}

The Nasina assemblage is a greenschist- to amphibolite-facies metasedimentary package that is generally interpreted to be in thrust contact with the Fortymile River assemblage. The two assemblages are broadly interpreted to be different facies of the same overall lithotectonic assemblage — the Finlayson assemblagein the Yukon (Colpron and others, 2006). Szumigala and others (2002) report local biotite, kyanite, and pyrophyllite, implying the rocks have been metamorphosed to upper greenschist facies. Felsic lithologies interlayered within this unit have yielded zircon $\mathrm{U}-\mathrm{Pb}$ ages from ca. 349 to $359 \mathrm{Ma}$ (Dusel-Bacon and others, 2006), and ca. $348 \mathrm{Ma}$ (Yukon Geological Survey, 2019). Mapping and unit descriptions for the Nasina assemblage in the northeastern portion of this map are adapted from Flynn (2003).

MDsqc CARBONACEOUS SCHIST AND QUARTZITE (DEVONIAN TO MISSISSIPPIAN)_Fine-grained, carbonaceous metasedimentary rocks. Predominantly dark-gray, carbonaceous, white mica-quartz schist and quartzite, graphite-quartz schist, and banded gray and massive light gray quartzite. Thin layers of white mica-quartz schist are locally interlayered on a scale of millimeters to centimeters in the carbonaceous schist and quartzite. Carbonaceous quartz schist and quartzite grades into biotite-quartz schist \pm carbonaceous material and quartzite \pm white mica in numerous areas. Biotite-feldspar-quartz schist \pm actinolite \pm white mica and white mica-feldspar-quartz metafelsite \pm biotite are present in a few locations. The carbonaceous quartz schist is locally calcareous, with rare small areas of marble rubble. Foliation is locally crenulated and mylonitic textures are present in some areas. Magnetic susceptibility of the unit is low; ranging from 0.01 to $0.15 \times 10^{-3}$ SI. Unit is interpreted to be part of the Nasina assemblage and is correlative with carbonaceous units to the north (MDq and MDkq) in the Eagle A-1 and A-2 quadrangles (Szumigala and others, 2002; Werdon and others, 2001) and with carbonaceous metasediments in the Finlayson assemblage (DMf3) in the Yukon (Yukon Geological Survey, 2019).

Pzgs GNEISS AND SCHIST (PALEOZOIC?)—Heterogeneous unit characterized by fine- to medium-grained gneiss and schist. Lithologies include biotite-muscovite-quartz schist \pm feldspar, quartz-albite-epidote-hornblende gneiss \pm biotite \pm feldspar \pm chlorite, biotite-quartz-epidote-hornblende schist, biotite-quartz-feldspar gneiss \pm muscovite \pm garnet, and muscovite-feldspar-quartz gneiss \pm biotite \pm sparse garnet. Some outcrops of gneiss and schist are intensely deformed, with complex folding. Magnetic susceptibility of felsic lithologies is low, ranging between 0.05 and $0.2 \times 10^{-3} \mathrm{SI}$. Magnetic susceptibility of lithologies with a substantial mafic component typically is moderate; ranging between 0.15 and $0.7 \times 10^{-3} \mathrm{SI}$, with sporadic higher values.

\section{METAMORPHIC ROCKS (AMPHIBOLITE FACIES) Allochthonous rocks of Fortymile River assemblage}

The Fortymile River assemblage comprises a heterogeneous group of amphibolite-grade metamorphic lithologies composed mainly of metasedimentary rocks (quartzite, semischist, schist, and paragneiss), which are interlayered with amphibolite and lesser orthogneiss. Regionally, the age of this assemblage is 
constrained by datable interlayered lithologies. Orthogneiss, interpreted as having a volcanic protolith, yielded zircon U-Pb ages of ca. 355 to $341 \mathrm{Ma}$ (Dusel-Bacon and others, 2006). Other felsic orthogneiss layers yielded Permian zircon U-Pb ages and apparently represent later intrusions (Jones and others, 2017a). The thick marble layer located west of the map area at the headwaters of Alder Creek in the Tanacross D-2 Quadrangle yielded a mid-Mississippian to early Permian conodont age (Dusel-Bacon and Harris, 2003). This assemblage is a part of the Yukon-Tanana terrane as defined by Dusel-Bacon and others (2006) and is correlative to Finlayson assemblage of Colpron and others (2006) in Canada. The boundary between the allochthonous Fortymile River assemblage and the parautochthonous Lake George assemblage is a regionally significant low-angle structure accommodating both contractional and subsequent extensional displacements (Dusel-Bacon and others, 2015). The Fortymile River assemblage is characterized by Triassic to Jurassic ${ }^{40} \mathrm{Ar} /{ }^{39} \mathrm{Ar}$ cooling ages, whereas all the cooling ages from Lake George are late Aptian to Albian (Dusel-Bacon and others, 2002; Jones and others, 2017a, 2017b; Naibert and others, 2018).

MDfa AMPHIBOLITE (MISSISSIPPIAN TO DEVONIAN)_Amphibolite and amphibole gneiss interlayed with subordinate amphibole-bearing gneiss, orthogneiss, quartz schist, and dark-gray quartzite on decimeter to multi-meter scales. The amphibolite is pale- to dark-green to graygreen, commonly with light peach-white bands, weathering brown, with foliated or gneissic texture. Foliation is defined by aligned amphibole, biotite, and/or chlorite. Amphibole and garnet locally form porphyroblasts. Grain size ranges from 0.05 to $40 \mathrm{~mm}$. Layers contain up to 98 percent amphibole, 15 percent feldspar, up to 10 percent biotite, 5 percent garnet, up to 88 percent chlorite, 3 percent quartz, 3 percent sericite, up to 5 percent magnetite, $0.05-$ 2 percent sulfides, and 1-5 percent epidote. Amphibolites are interlayered with subordinate amphibole-bearing gneiss, orthogneiss, quartz schist, and dark-gray quartzite on decimeter to multi-meter scales. Amphibole is dominantly euhedral with grains ranging up to $40 \mathrm{~mm}$ in length; less commonly acicular. Hornblende is the dominant amphibole, but actinolite is locally present. Disseminated sulfides (pyrite and pyrrhotite) up to $5 \mathrm{~mm}$ in diameter were observed in some outcrops. Quartzofeldspathic augen up to $15 \mathrm{~mm}$ in diameter and rare quartz phenocrysts or xenocrysts were also observed. Plagioclase is generally interstitial. Magnetic susceptibility varies widely, and depends on how mafic the amphibolite is and its magnetite content. Magnetic susceptibility measurements are generally low, ranging between 0.04 and $36.6 \times 10^{-3} \mathrm{SI}$, with an average of $0.52 \times 10^{-3} \mathrm{SI}$. Amphibolite bodies are thin, up to $30 \mathrm{~m}$, with the exception of one 70-m-thick body. Amphibolites have predominantly volcanic arc trace-element-indicated signatures, with some within-plate signatures (Dusel-Bacon and others, 2009; Wypych and others, 2018). Similar amphibolites have been divided into three different units by Werdon and others (2001): Amphibole-feldspar gneiss (pMaf), amphibolite and gneiss (pMa), and amphibolite (pMam) and into four units by Szumigala and others (2002): amphibolite and gneiss (pMag), amphibolite, gneiss, and schist (pMa), amphibolite (pMam), and amphibolite, paragneiss, and schist (Pza). Similar rocks have been combined with intermediate and mafic metavolcanic rocks into the Finlayson assemblage unit DMf1 by the Yukon Geological Survey (2019). A sample from this unit yielded a zircon $\mathrm{U}-\mathrm{Pb}$ age of $336.9 \pm 3.8 \mathrm{Ma}$, which is interpreted to be the age of the mafic igneous protolith (Wypych and others, 2020).

MDfo ORTHOGNEISS (MISSISSIPPIAN TO DEVONIAN)_Primarily orthogneiss with subordinate interlayered amphibolite and paragneiss. Outcrops are weakly to moderately foliated, grain size ranges from 0.1 to $15 \mathrm{~mm}$, and feldspar augen are rare. Orthogneiss chemistry suggests protoliths range from intermediate to felsic calc-alkaline. Unit contains 30-80 percent pla- 
gioclase feldspar, up to 30 percent potassium feldspar, 20-55 percent quartz, up to 45 percent hornblende, 3-25 percent biotite, 1-12 percent muscovite, 5-40 percent chlorite, and up to 5 percent garnet; interstitial calcite occurs locally. Accessory minerals include epidote, hematite, magnetite, and pyrite. Petrography shows weak to moderate foliation defined by muscovite and biotite and the presence of an S-C fabric. Magnetic susceptibility measurements were generally low, ranging between 0.04 and $10.5 \times 10^{-3} \mathrm{SI}$, with an average of $0.18 \times 10^{-3} \mathrm{SI}$. In the Eagle A-1 Quadrangle, this unit is split into tonalitic orthogneiss (Motn), felsic orthogneiss (Mog), and undifferentiated orthogneiss (Mo; Szumigala and others, 2002). Trondhjemitic orthogneiss (Motr) was also mapped in the Eagle A-1 Quadrangle and was observed in the Tanacross Quadrangle at multiple localities, mainly as dikes that were not spatially extensive enough to map. These trondjemitic metadikes are leucocratic medium-grained, massive to weakly foliated quartz-plagioclase gneiss and minor white mica up to 15 percent. Orthogneiss interlayered with metasedimentary units and amphibolites may have originated as sills or depositionally interlayered volcanic rocks. Volcanic protoliths were interpreted for fine-grained orthogneisses in this unit (Dusel-Bacon and others, 2015) and metavolcanics make up a significant portion of the correlative unit Mo in the adjacent Eagle Quadrangle (Szumigala, 2002). Zircon from undifferentiated orthogneiss in the Eagle A-1 Quadrangle yielded a U-Pb age of $343 \pm 4 \mathrm{Ma}$ (Day and others, 2002), and a sample from this map area yielded zircon age of $341.1 \pm 2.3 \mathrm{Ma}$ (Wypych and others, 2020). These ages are interpreted to represent crystallization of the igneous protoliths.

MDfmb MARBLE AND IMPURE MARBLE (MISSISSIPPIAN TO DEVONIAN) - White to gray, medium- to very coarse-grained, crystalline calcite marble. Marble is locally dolomitic and epidote-bearing, has quartzose layers, and is sparsely micaceous (Flynn, 2003). Magnetic susceptibility of this unit is very low, generally $0.1 \times 10^{-3} \mathrm{SI}$ or lower. This unit forms beds within metasedimentary and orthogneiss packages of Fortymile River assemblage. The unit is correlated with the marble and calcareous rocks unit (pMm) mapped in the Eagle A-1 and A-2 quadrangles (Szumigala and others, 2002; Werdon and others, 2001) and the Finlayson assemblage marble unit (DMf5) on the Yukon bedrock geologic map (Yukon Geological Survey, 2019). The age range of this unit is inferred from regional zircon data (Jones and others, 2017b) and interlayered felsic metavolcanic rocks (orthogneiss) dated by U-Pb zircon methods (Day and others, 2002), although conodont evidence suggests the unit could be as young as early Early Permian (Dusel-Bacon and Harris, 2003). Heterogeneous unit consisting of interlayered schist, quartz schist, semischist, quartzite, and paragneiss, with subordinate greenschist and carbonate-silicate schist. Marble, impure marble, and graphitic quartzite layers are present locally. Schist, quartz schist, and semischist contain 3-75 percent muscovite, up to 30 percent biotite, up to 85 percent quartz, up to 15 percent feldspar, and up to 35 percent garnet. Garnet porphyroblasts are typically $1-3 \mathrm{~mm}$ in diameter and rarely up to $5 \mathrm{~mm}$. Schistosity is defined by muscovite and fine-grained quartz, chloritized biotite, and garnet porphyroblasts, which are commonly altered to biotite or chlorite along fractures and along grain edges. Feldspars are commonly altered to sericite. Paragneisses have similar mineralogy, with higher feldspar content (up to 60 percent) and less muscovite. Gneissic foliation is defined by quartz- and feldspar-rich bands separating quartz- and mica-rich bands. Gneissic foliation varies from weakly to strongly foliated. Quartzite contains 85-99 percent quartz, with anhedral crystals $0.05-1 \mathrm{~mm}$ in diameter. Quartzite foliation is defined by elongate 
quartz grains and 1-15 percent micas, dominantly muscovite with minor chloritized biotite. Accessory minerals include epidote/clinozoisite and graphite. Strong S-C fabric, multiple foliation orientations, and small-scale folding indicate the unit has undergone multiple deformation events. The unit contains relatively thin (less than $10 \mathrm{~m}$ thick) interlayered amphibolite, and is cut by thin, up to $0.5 \mathrm{~m}$ thick, trondhjemitic orthogneiss dikes and sills as well as unmetamorphosed to weakly metamorphosed diorite, granite, granodiorite, and pegmatite dikes. Magnetic susceptibility measurements showed a broad range between 0.02 and $46.9 \times 10^{-3}$ SI with an average of $0.16 \times 10^{-3} \mathrm{SI}$. The metasedimentary unit is estimated to be more than $600 \mathrm{~m}$ thick. Detrital zircons were dated from two samples of quartzite from this unit. The youngest populations of ages from those samples are 258.0 \pm 3.4 and 264.9 $\pm 4.6 \mathrm{Ma}$ (Wypych and others, 2020), which are interpreted as metamorphic zircon overgrowths typical of allochthonous rocks. The maximum deposition age of the quartzite is Paleozoic (Wypych and others, 2020). Szumigala and others (2002) and Werdon and others (2001) divide this unit into quartzite (pMq) and quartzite-paragneiss schist (pMqgs) units. The Yukon bedrock geologic map describes a similar unit as Finlayson assemblage felsic metavolcanics and quartz-muscovite schist (DMf2; Yukon Geological Survey, 2019).

MDfp PARAGNEISS (MISSISSIPPIAN TO DEVONIAN)—Paragneiss with subordinate interlayered amphibolite, orthogneiss, and thin marble. Grain size ranges from 0.05 to $15 \mathrm{~mm}$ with moderate to strong foliation. Paragneiss contains 30-88 percent quartz, 1-20 percent biotite, 5-15 percent chlorite, 20-55 percent feldspar, 2-10 percent muscovite, 5-20 percent calcite, up to 1 percent garnet, minor hornblende, and trace magnetite. A couple samples in the vicinity of the detachment have been highly altered, with up to 55 percent sericite in one of the samples; up to 1.5 percent pyrrhotite was observed near this sericite-altered sample. Magnetic susceptibility measurements are generally low, ranging between 0.04 and $11.1 \times 10^{-3} \mathrm{SI}$, with an average of 0.30 $x 10^{-3}$ SI. This unit is relatively uncommon in the map area, and is less than $150 \mathrm{~m}$ thick. Similar units have been described in the Eagle A-1 and A-2 quadrangles (Szumigala and others, 2002; Werdon and others, 2001) as schist and paragneiss (pMsg) and gneiss (pMg).

\section{Parautochthonous rocks of Lake George assemblage}

The Lake George assemblage represents the parautochthonous North America assemblage (pNA) in the map area and is dominated by augen gneiss (MDag) and orthogneiss (MDlo, MDlom). Orthogneiss forms tabular bodies intruding, or interlayered with, homogeneous metasedimentary (predominantly quartzite and semischist) rocks with occasional amphibolite layers and bodies. The metasedimentary and orthogneiss package is intruded by augen gneiss of plutonic origin (unit MDag). The assemblage is metamorphosed to amphibolite grade.

MDag DIVIDE MOUNTAIN AUGEN GNEISS (MISSISSIPPIAN TO LATE DEVONIAN)_ Granite and locally granodiorite orthogneiss with prominent potassium feldspar augens up to $10 \mathrm{~cm}$ long. Pale cream, pale gray, and pale pink; weathers pink gray. The meta-intrusions is porphyroclastic and coarse grained near the center, and finer grained and sheared toward the edges. The unit consists of up to 70 percent feldspar, with up to 40 percent potassium feldspar augen, 20-40 percent quartz, up to 10 percent plagioclase porphyroclasts, about 10 percent mica (biotite, muscovite, or both), and local trace tourmaline. In the vicinity of Cretaceous intrusions, the augen gneiss is locally highly altered, sericitized, and brecciated. Anhedral feldspar crystals are about $0.5 \mathrm{~mm}$ long, often recrystallized, with no twinning. Sericitization was observed in some 
samples. Plagioclase is anhedral, with clear polysynthetic twinning, and some samples preserve myrmekite textures. Anhedral quartz up to $0.5 \mathrm{~mm}$ in diameter has slight to strong undulatory extinction and forms approximately 1 -mm-thick quartzose layers. The felsic layers are parted by thin muscovite and biotite layers. Biotite often has inclusions of opaque minerals and in some instances about 10 percent of biotite crystals are chloritized. Feldspar augen vary in size, from as small as a few millimeters up to $10 \mathrm{~cm}$ in length. The stretching of the augen seems dependent on the location within the body; more stretching and shearing are observed near the edges. This results in preservation of original igneous textures in some areas away from contacts. The nonstretched or weakly stretched feldspars are subhedral, twinned, and are often rotated. Recrystallized augen usually have no twinning preserved. Samples have accessory relict garnet, zircon, and opaque minerals. The unit is locally altered to chlorite, tourmaline, and sericite. The rocks are often cut by quartz veins (up to 20 -cm thick) and pegmatite dikes. The augen gneisses are the main unit observed for the Lake George assemblage, and are characteristically non-magnetic to weakly magnetic, ranging from 0.03 to $0.2 \times 10^{-3} \mathrm{SI}$. One augen gneiss yielded a $\mathrm{U}-\mathrm{Pb}$ zircon crystallization age of $355.0 \pm 4.5 \mathrm{Ma}$ (Todd and others, 2019). The augen gneiss can be correlated with the Lake George orthogneiss along the Alaska Highway (Solie and others, 2019).

MDIo ORTHOGNEISS (MISSISSIPPIAN TO DEVONIAN) — Orthogneiss with diorite to granite composition occurring as tabular bodies interlayered with minor quartzite, paragneiss, amphibolite, and schist. Black and white in color, weathering gray to orange, foliated, with grain size ranging from 0.5 to $7 \mathrm{~mm}$. Mineral composition varies: up to 5 percent quartz in dioritic orthogneiss to 60 percent in granitic varieties, 85 and 15 percent feldspar, respectively, and between 15 and 20 percent biotite, up to 9 percent white mica, and up to 1 percent garnet. Accessory minerals include zircon, fluorite, epidote, and chlorite. Quartz crystals are subhedral to anhedral with undulatory extinction and grain size ranges from 0.1 to $2 \mathrm{~mm}$. Anhedral to subhedral feldspars include plagioclase and microcline, which are largely recrystallized, have no twinning, range in size from 0.5 to $2 \mathrm{~mm}$, and are commonly replaced by sericite (up to 50 percent replacement). Biotite is up to $2-\mathrm{mm}$ long with birds-eye extinction and rare chloritization along edges. Weak foliation is defined by biotite and fine-grained muscovite in irregular submm-thick mica bands. Bodies are non-magnetic with measured susceptibilities between 0.01 and $0.2 \times 10^{-3} \mathrm{SI}$. The tabular bodies vary in thickness from $30 \mathrm{~cm}$ to about $300 \mathrm{~m}$. This unit differs from augen orthogneiss (MDag) in: 1) lack of large potassium feldspar augen, 2) greater compositional range, and 3) greater heterogeneity and interlayering with metasedimentary rocks. A granite orthogneiss sample yielded a $\mathrm{U}-\mathrm{Pb}$ zircon crystallization age of 370.6 $9.6 \mathrm{Ma}$ (Todd and others, 2019). This unit is included in the undifferentiated orthogneiss (unit MDlo) of Solie and others (2019).

MDIom ORTHOGNEISS, MAGNETIC (MISSISSIPPIAN TO DEVONIAN)_-Magnetite-bearing felsic orthogneiss. Light pink, foliated, with grain size between 0.1 and $5 \mathrm{~mm}$. Mineral composition includes: 74 percent feldspar, 25 percent anhedral quartz, and 1 percent magnetite. Foliation planes are defined by biotite. This unit is no more than $30-\mathrm{m}$ thick and it is observed north of Fishhook Bend in the Tanacross D-1 Quadrangle. Magnetic susceptibility ranges between 6 and $15 \times 10^{-3} \mathrm{SI}$.

MDla AMPHIBOLITE (MISSISSIPPIAN TO DEVONIAN)_Amphibolite to amphibole-bearing gneiss located south of North Ladue River near the Alaska-Canada border. Dark green to gray, 
weathering brown, foliated, gneissic, and with grain sizes of 1-3 $\mathrm{mm}$. Mineral composition includes 55-85 percent amphibole, 4-50 percent plagioclase, up to 3 percent biotite, and rare quartz that is present locally. One anomalous sample has 5 percent quartz, one sample has 48 percent of chlorite, and two samples have 55 and 95 percent metamorphic clinopyroxene. Minerals are generally fresh with strong lineation defined by amphibole. Veins cutting the unit are 1-7 mm thick and contain feldspar and quartz. The magnetic susceptibility has a relatively narrow range of $0.25-0.49 \times 10^{-3} \mathrm{SI}$. Amphibolite is characterized by a strong within-plate geochemical signature, but volcanic arc trace-element-indicated signatures are present as well. This amphibolite is correlated with Lake George assemblage amphibolite (pMa) from the Alaska Highway Corridor (Solie and others, 2019).

AMPHIBOLITE AND SERPENTINITE (MISSISSIPPIAN TO DEVONIAN)_Amphibolite, amphibole orthogneiss, serpentinite, and clinopyroxenite occurring within Lake George assemblage north of McElfish Creek in the Tanacross C-2 Quadrangle. These units occur together and comprise several, approximately 300-m-thick, tabular bodies that trend east-west and dip 60-80 degrees to the north. All lithologies are black to dark green and weather orange, brown, or black. The rocks are foliated, with grain size ranging from 0.2 to $40 \mathrm{~mm}$. Amphibolite and amphibole orthogneiss are composed of 40-95 percent tabular hornblende, 4-50 percent plagioclase, 1-10 percent biotite, and rare samples have up to 40 percent quartz and 0.3 percent pyrite clots. Hornblende is up to $30 \mathrm{~mm}$ long and often is rimmed with actinolite. Rare gabbro has 55 percent euhedral metamorphic clinopyroxene, 43 percent feldspar, and 2 percent epidote. Gabbro is moderately foliated with no appreciable compositional banding. Pyroxene crystals are vitreous, euhedral, and preferentially oriented; interstitial space is filled with granular feldspar. Thin feldspathic veinlets run parallel to foliation and have an epidote alteration rind approximately 3-6 $\mathrm{mm}$ wide. Serpentinite is porphyroblastic with weak to no foliation and is composed of 30-75 percent serpentine, up to 60 percent hornblende, up to 40 percent tremolite and anthophyllite, up to 20 percent olivine, and 5 percent vein-filling magnetite. Talc and relict orthopyroxene were observed in thin section. The serpentine and talc creates a groundmass for relict olivine, orthopyroxene, and up to 40 -mm-long acicular hornblende. This mineralogy is consistent with amphibolite-facies regional metamorphism. The serpentinites are highly magnetic, with magnetic susceptibilities ranging from 16 to $138 \times 10^{-3}$ SI with mean of about $30 \times 10^{-3}$ SI, whereas the amphibolites have a mean of about $8 \times 10^{-3} \mathrm{SI}$. The amphibolites have a primitive mid ocean ridge basalt trace-element-indicated chemical composition. Occurring together, the amphibolite and serpentinite appear to be the metamorphosed equivalent of differentiated mafic-ultramafic intrusions. An amphibolite sample yielded a zircon $\mathrm{U}-\mathrm{Pb}$ age of $360.5 \pm 3.6 \mathrm{Ma}$, which is interpreted to represent crystallization of the igneous protolith (Wypych and others, 2020).

pMIms METASEDIMENTARY ROCKS (PRE-MISSISSIPPIAN)—Quartzite, semischist, and schist with subordinate paragneiss, marble, amphibole-bearing gneiss, and mafic metavolcanic rocks. Quartzites are gray or pale green, and locally weather brown to orange. Quartzite is weakly foliated with grain size ranging from 0.01 to $3 \mathrm{~mm}$, and is composed of up to 96 percent anhedral quartz parted by single-crystal layers of white mica (up to 14 percent) and/or biotite (up to 10 percent). Some quartzite contains up to 1 percent garnet porphyroblasts reaching 3-mm in diameter. Schist and semischist are pale gray, silver, silver-pink, and white; weathering tan to orange with local iron staining. Schist and semischist are foliated, lineated, and often porphy- 
roblastic, with grain size ranging from 0.05 to $18 \mathrm{~mm}$. Felsic layers in the schist and semischist are composed of 0.5 - to 1 -mm-diameter quartz (20 to 85 percent), and 0.5 - to 1 -mm-diameter feldspar (2-40 percent), parted by sub-millimeter-thick mica layers (up to 40 percent) with chlorite replacing biotite, and rare graphite. Samples have 0.5-4 percent euhedral porphyroblasts of garnet up to $18-\mathrm{mm}$ in diameter. Subordinate paragneiss is the most common minor lithology; it has a nearly identical mineral composition to the semischist and schist but differs in texture - exhibiting gneissic banding and a generally coarser grain size. Rare amphibole-bearing gneisses and mafic metavolcanic rocks are characterized by up to 40 percent amphibole, 15 percent chlorite, up to 20 percent feldspar, and up to 15 percent quartz. A couple of foliation-parallel beds of marble have been described near the detachment separating the unit from the Fortymile River assemblage to the north in the Tanacross D-1 Quadrangle. Marbles are tan to gray, granoblastic, and have grain size ranging from 1 to $2 \mathrm{~mm}$. Interlayered marbles are 93 percent calcite, 5 percent quartz, 1 percent muscovite, and 1 percent biotite. Metasedimentary lithologies of this unit have low magnetic susceptibility ranging between 0.01 and $1.84 \times 10^{-3} \mathrm{SI}$ and averaging about $0.4 \times 10^{-3} \mathrm{SI}$. The amphibole-rich layers however can reach up to $28.8 \times 10^{-3}$ SI. This unit is more than $300 \mathrm{~m}$ thick and can be correlated with the Scottie Creek Formation in Canada (Yukon Geologic Survey, 2019), and paragneiss and schist, quartzite and felsic schist, and quartzite of Lake George assemblage in Alaska (Solie and others, 2019).

pMIp PARAGNEISS (DEVONIAN TO PRE-MISSISSIPPIAN)—Paragneiss interlayered with subordinate orthogneiss, quartzite, semischist, schist, and amphibolite. Unit is intruded by augen gneiss (MDag) as well as Cretaceous granitoids, pegmatite and aplite dikes, and Late Cretaceous porphyry intrusions (Kg, Kfg, $\mathrm{Kv}$ and $\mathrm{Ktgd}$ ). Paragneiss is predominantly black and white or tan to dark gray, weathering orange to gray. Paragneiss is foliated with gneissic textures and grain sizes ranging from 0.1 to $8 \mathrm{~mm}$. Composed of 30- 70 percent quartz, $10-70$ percent feldspar, 2-35 percent biotite, 1-15 percent white mica, and up to 5 percent garnet as porphyroblasts, and has local tourmaline-rich layers. Alternating 0.25-7.5 centimeter layers consist of whitetan quartzofeldspathic bands and dark biotite-dominant bands. Garnetiferous bands seem to be concentrated in zones of highest ductile deformation. Interlayered lithologies are of similar composition as those described for Lake George metasedimentary unit (MDlms). This unit is over $300 \mathrm{~m}$ thick, and characterized by low magnetic susceptibility between 0.06 and $0.47 \mathrm{x}$ $10^{-3} \mathrm{SI}$ with a mean of $0.15 \times 10^{-3} \mathrm{SI}$. Correlated with the Scottie Creek Formation in Canada (Yukon Geological Survey, 2019) and with paragneiss and schist, quartzite and felsic schist, and quartzite of Lake George assemblage in Alaska (Solie and others, 2019).

\section{ACKNOWLEDGMENTS}

The DGGS Northeast Tanacross project was funded by the USGS National Cooperative Geologic Mapping Program under STATEMAP award number G18AC00137 for 2018 and by State of Alaska general funds.

We would like to thank James V. Jones III (USGS, Anchorage) and Robert Gillis (DGGS) for thorough and constructive reviews of the geologic map, map unit descriptions, and report. 


\section{REFERENCES}

Abbot, J.G., 1983, Origin of the Clinton Creek asbestos deposit; Yukon Geology and Exploration, 1982: Department of Indian and Northern Affairs, Canada, p. 18-25

Allan, M.M., Mortensen, J.K., Hart, C.J.R., Bailey, L.A., Sánchez, M.G., Ciolkiewicz, Witold, McKenzie, G.G., and Creaser, R.A., 2013, Magmatic and metallogenic framework of westcentral Yukon and eastern Alaska, in Colpron, Maurice, Bissig, Thomas, Rusk, B.G., and Thompson, J.F.H eds., Tectonics, Metallogeny, and Discovery: The North American Cordillera and Similar Accretionary Settings, Society of Economic Geologists Inc. Special Publication 17, p. 111-168.

Andronikov, A. V., and Mukasa, S.B., 2010, ${ }^{40} \mathrm{Ar} /{ }^{39} \mathrm{Ar}$ eruption ages and geochemical characteristics of Late Tertiary to Quaternary intraplate and arc-related lavas in interior Alaska: Lithos, v. 115 , no. $1-4$, p. 1-14.

Blondes, M.S., Reiners, P.W., Edwards, B.R., and Biscontini, Andrew, 2007, Dating young basalt eruptions by (U-Th)/He on xenolithic zircons: Geology, v. 35, no. 1, p. 17-20.

Colpron, Maurice, Nelson, J.L., and Murphy, D.C., 2006, A tectonostratigraphic framework for the pericratonic terranes of the northern Canadian Cordillera, in Colpron, Maurice, and Nelson, J.L., eds., Paleozoic evolution and metallogeny of pericratonic terranes at the ancient Pacific margin of North America, Canadian and Alaskan Cordillera: Geological Association of Canada Special Paper, v. 45, p. 1-23.

Day, W.C., Aleinikoff, J.N., and Gamble, B.M., 2002, Geochemistry and age constraints on metamorphism and deformation in the Fortymile River Area, Eastern Yukon-Tanana Upland, Alaska, in Wilson, F.H., and Galloway, J.P., eds., Studies by the U.S. Geological Survey in Alaska, 2000: U.S. Geological Survey Professional Paper 1662, p. 5-18.

Dusel-Bacon, Cynthia, Aleinikoff, J.N., Day, W.C., and Mortensen, J.K., 2015, Mesozoic magmatism and timing of epigenetic $\mathrm{Pb}-\mathrm{Zn}-\mathrm{Ag}$ mineralization in the western Fortymile mining district, east-central Alaska: Zircon U-Pb geochronology, whole-rock geochemistry, and Pb isotopes: Geosphere, v. 11, no. 3, p. 786-822. Dusel-Bacon, Cynthia, and Harris, A.G., 2003, New occurrences of late Paleozoic and Triassic fossils from the Seventymile and Yukon-Tanana Terranes, east-central Alaska, with comments on previously published occurrences in the same area: Studies by the U.S. Geological Survey in Alaska, 2001: U.S. Geological Survey Professional Paper 1678, p. 5-30.

Dusel-Bacon, Cynthia, Holm-Denoma, C.S., Jones, J.V.,III, Aleinikoff, J.N., and Mortensen, J.K., 2017, Detrital zircon geochronology of quartzose metasedimentary rocks from parautochthonous North America, east-central Alaska: Lithosphere, no. 5, p. 1-26.

Dusel-Bacon, Cynthia, Hopkins, M.J., Mortensen, J.K., Dashevsky, S.S., Bressler, J.R., and Day, W.C., 2006, Paleozoic tectonic and metallogenic evolution of the pericratonic rocks of east-central Alaska and adjacent Yukon, in Colpron, Maurice and Nelson J.L., eds., Paleozoic Evolution and Metallogeny of Pericratonic Terranes at the Ancient Pacific Margin of North America, Canadian and Alaskan Cordillera: Geological Association of Canada Special Paper 45, p. 25-74. Dusel-Bacon, Cynthia, Lanphere, M.A., Sharp, W.D., Layer, P.W., and Hansen, V.L., 2002, Mesozoic thermal history and timing of structural events for the Yukon-Tanana Upland, east-central Alaska: ${ }^{40} \mathrm{Ar} /{ }^{39} \mathrm{Ar}$ data from metamorphic and plutonic rocks: Canadian Journal of Earth Sciences, v. 39, no. 6, p. 1,013-1,051. doi.org/10.1139/e02-018

Dusel-Bacon, Cynthia, Slack, J.F., Aleinikoff, J.N., and Mortensen, J.K., 2009, Mesozoic magmatism and base-metal mineralization in the Fortymile mining district, eastern Alaskainitial results of petrographic, geochemical, and isotopic studies in the Mount Veta area: Studies by the U.S. Geological Survey in Alaska, 2007: U.S. Geological Survey Professional Paper 1760A, p. 1-42.

Flynn, R.L., 2003, Geology of the Boundary area, Eagle A-1 and Tanacross D-1 quadrangles, east- 
central Alaska: Fairbanks, Alaska, University of Alaska Fairbanks, M.S. thesis, 185 p.

1970, Reconnaissance geologic map of the

Tanacross Quadrangle, Alaska: U.S. Geological Survey Miscellaneous Geologic Investigations Map 593, 1 sheet, scale 1:250,000.

Foster, H.L., Albert, N.R.D., Barnes, D.F., Curtin, G.C., Griscom, Andrew, Singer, D.A., and Smith, J.G., 1976, The Alaskan Mineral Resource Assessment Program; background information to accompany folio of geologic and mineral resource maps of the Tanacross Quadrangle, Alaska: U.S. Geological Survey Circular 734, 19 p.

Foster, H.L., and Igarashi, Yaeko, 1990, Fossil pollen from nonmarine sedimentary rocks of the eastern Yukon-Tanana region, east-central Alaska, in Dover, J.H., and Galloway, J.P., eds., Geologic Studies in Alaska by the U.S. Geological Survey, 1989: U.S. Geological Survey Bulletin 1946, p. 11-20.

Jackson, L.E.J., 2005a, Surficial geology, Borden Creek, Yukon Territory: Geological Survey of Canada, Open File 4578, 2005, 1 sheet. 2005b, Surficial geology, Crag Mountain, Yukon Territory: Geological Survey of Canada, Open File 4579, 2005, 1 sheet.

Jones, J.V., III, Todd, Erin, Caine, J.S., HolmDenoma, C.S., Ryan, J.J., and Benowitz, J.A., 2017a, Late Permian (ca. 267-257 Ma) magmatism, deformation, and metamorphism and lithotectonic associations of the Ladue River unit in east-central Alaska: Geological Society of America Abstracts with Programs, v. 49, no. 6. doi.org/10.1130/abs/2017AM-304170

Jones, J.V., III, Todd, Erin, Caine, J.S., Holm-Denoma, C.S., Ryan, J.J., Benowitz, J.A., and Drenth, B.J., 2017b, Unraveling the boundary between the Yukon-Tanana terrane and parautochthonous North America in eastern Alaska: Geological Society of AmericaAbstracts with Programs, v. 49, no. 6. doi.org/10.1130/abs/2017AM-304142

Murphy, D.C., Mortensen, J.K., and van Staal, C.R., 2009, 'Windy-McKinley' terrane, western Yukon: New data bearing on its composition, age, correlation and paleotectonic settings, in
Weston, L.H., Blackburn, L.R., and Lewis, L.L., eds., Yukon Exploration and Geology, 2008: Yukon Geological Survey, p. 195-209.

Naibert, T.J., Benowitz, J.A., Wypych, Alicja, Sicard, K.R., and Twelker, Evan, 2018, ${ }^{40} \mathrm{Ar} /{ }^{39} \mathrm{Ar}$ data from the Tanacross D-1 and D-2, Big Delta B-4 and B-5, and Mount Hayes A-6 quadrangles, Alaska: Alaska Division of Geological \& Geophysical Surveys Raw Data File 2018-3, p. 15 p. doi.org/10.14509/30112

Péwé, T.L., Burbank, Lawrence, and Mayo, L.R., 1967, Multiple glaciation of the YukonTanana upland, Alaska: U.S. Geological Survey Miscellaneous Geologic Investigations Map 507, 1 sheet.

Pinney, D.S., 2001, Surficial-geologic map of the Eagle A-2 Quadrangle, Fortymile mining district, Alaska: Alaska Division of Geological \& Geophysical Surveys Preliminary Interpretive Report 2001-3C, 1 sheet, scale 1:63,360. doi.org/10.14509/2671

Solie, D.N., Werdon, M.B., Freeman, L.K., Newberry, R.J., Szumigala, D.J., Speeter, G.G., and Elliott B.A., 2019, Bedrock-geologic map, Alaska Highway Corridor, Tetlin Junction, Alaska, to Canada Border: Alaska Division of Geological \& Geophysical Surveys Preliminary Interpretative Report 2019-3, 16 p., 2 sheets, scale 1:63,360. doi.org/10.14509/30038

Stevens, D.S.P., and Burns, P.A.C., 2010, Surficialgeologic map of the Eagle A-1 Quadrangle, Fortymile mining district: Alaska Division of Geological \& Geophysical Surveys Preliminary Interpretive Report 2002-1C, 1 sheet, scale 1:63,360. doi.org/10.14509/22081

Szumigala, D.J., Newberry, R.J., Werdon, M.B., Athey, J.E., Stevens, D.S.P., Flynn, R.L., Clautice, K.H., and Craw, P.A., 2002, Geologic map of the Eagle A-1 Quadrangle, Fortymile mining district: Alaska Division of Geological \& Geophysical Surveys Preliminary Interpretive Report 2002-1A, 1 sheet, scale 1:63,360. doi.org/10.14509/2863

Twelker, Evan, Newberry, R.J., Wypych, Alicja, Naibert, T.J., Wildland, A.D., Sicard, K.R., Regan, S.P., Athey, J.E., Wyatt, W.C., and Lopez, J.A., 2021, Bedrock geologic map of the La- 
due River-Mount Fairplay area, Tanacross and Nabesna quadrangles, Alaska, in Twelker, Evan, ed., Geologic investigation of the Ladue River-Mount Fairplay area, eastern Alaska: Alaska Division of Geological \& Geophysical Surveys Report of Investigation 2021-5A, p. 1-32, 1 sheet, scale 1:100,000. doi.org/10.14509/30735 Todd, Erin, Wypych, Alicja, and Kylander-Clark, Andrew, 2019, U-Pb and Lu-Hf isotope, age, and trace element data from zircon separates from northeastern Tanacross, Tanacross D-1, and parts of D-2, C-1, and C-2 quadrangles: Alaska Division of Geological \& Geophysical Surveys Raw Data File 2019-5. doi.org/10.14509/30198 Weber, F.R., 1986, Glacial geology of the YukonTanana Upland, in Hamilton, T.D., Reed, K.M., and Thorson, R.M., eds., Glaciation in Alaska-The Geologic record: Anchorage, Alaska Geological Society, p. 79-98.

Weber, F.R., and Wilson, F.H., 2012, Map showing extent of glaciation in the Eagle quadrangle, east-central Alaska: U.S. Geological Survey Open-File Report 2012-1138, scale 1:250,000.

Werdon, M.B., Newberry, R.J., Szumigala, D.J., and Pinney, D.S., 2001, Geologic map of the Eagle A-2 Quadrangle, Fortymile mining district, Alaska: Alaska Division of Geological \& Geophysical Surveys Preliminary Interpretive Report 2001-3A, 1 sheet, scale 1:63,360, v. 1.0.1. doi.org/10.14509/2669
Wypych, Alicja, Jones, J.V., III, and O'Sullivan, Paul, 2020, U-Pb Zircon ages from bedrock samples collected in the Tanacross D-1, and parts of the D-2, C-1, and C-2 quadrangles, Alaska: Alaska Division of Geological \& Geophysical Surveys Preliminary Interpretive Report 2020-2, 19 p. http://doi.org/10.14509/30465

Wypych, Alicja, Naibert, T.J., Athey, J.E., Newberry, R.J., Sicard, K.R., Twelker, Evan, Werdon, M.B., Willingham, A.L., and Wyatt, W.C., 2018, Major-oxide and trace-element geochemical data from rocks collected in 2018 for the Northeast Tanacross project, Tanacross C-1, C-2, D-1, and D-2 quadrangles, Alaska: Alaska Division of Geological \& Geophysical Surveys Raw Data File 2018-4, 4 p. doi.org/10.14509/30113

Wypych, Alicja, Twelker, Evan, Athey, J.E., Lockett, A.C., Naibert, T.J., Sicard, K.R., Werdon, M.B., and Willingham, A.L., 2017, Major-oxide and trace-element geochemical data from rocks collected in the Tanacross C-1, D-1, and D-2 quadrangles, Alaska in 2017: Alaska Division of Geological \& Geophysical Surveys Raw Data File 2017-10, 4 p. doi.org/10.14509/29778

Yukon Geological Survey, 2019, Yukon Digital Bedrock Geology. www.geology.gov.yk.cal update_yukon_bedrock_geology_map.html [accessed: 3/19/2019] 


\section{CHAPTER C: METAMORPHIC COOLING HISTORY OF THE FORTYMILE RIVER AND LAKE GEORGE ASSEMBLAGES FROM ${ }^{40} A R /{ }^{39} A R$ GEOCHRONOLOGY FROM THE NORTHEAST TANACROSS AND SOUTHEAST EAGLE QUADRANGLES, ALASKA}

Travis J. Naibert ${ }^{1}$, Alicja Wypych ${ }^{1}$, Evan Twelker ${ }^{1}$, an Jeffrey A. Benowitz ${ }^{2}$

\section{INTRODUCTION}

This report presents interpretations of ${ }^{40} \mathrm{Ar} /{ }^{39} \mathrm{Ar}$ ages of metamorphic rocks from the northeast Tanacross and southeast Eagle quadrangles, Alaska, which lie within the Yukon-Tanana Upland and cover the boundary between the Fortymile River and Lake George Assemblages (Dusel-Bacon and others, 2006). Recent 1:63,360 scale mapping by the Alaska Division of Geological \& Geophysical Surveys (DGGS) (Wypych and others, 2021, sheet 1) delineated the boundary between parautochthonous North America (Lake George assemblage) and the allochthonous Fortymile River assemblage of the Yukon Tanana terrane. The exact nature of the boundary is difficult to assess due to poor exposure and segmentation of the boundary by subsequent Cenozoic strike-slip faulting, but it is mapped as an extensional detachment as proposed by Hansen and Dusel-Bacon (1998). DGGS samples for this study, reported in Naibert and others (2020) were analyzed from both sides of the detachment to confirm the mapping in areas of poor bedrock exposure. We synthesize the new data, along with ${ }^{40} \mathrm{Ar} /{ }^{39} \mathrm{Ar}$ and $\mathrm{K}-\mathrm{Ar}$ ages from digital data in Wilson and others (2015 and references therein) and from Jones and Benowitz (2020), to further constrain the cooling histories of metamorphic rocks on either side of the detachment and to further refine the timing and rates of exhumation of the terranes on either side of the detachment.

\section{METHODS}

Methods of sample collection and preparation, analytical methods, sample descriptions, and discussion of preferred ${ }^{40} \mathrm{Ar} /{ }^{39} \mathrm{Ar}$ ages for the 16 metamorphic samples collected during the DGGS northeast Tanacross Quadrangle mapping project were reported in Naibert and others (2020). Muscovite is the most common potassium-bearing mineral in amphibolite-facies metasedimentary and metaplutonic rocks in both the Fortymile River and Lake George assemblages in the northeast Tanacross quadrangle, followed by biotite. Fourteen ${ }^{40} \mathrm{Ar} /{ }^{39} \mathrm{Ar}$ ages were calculated from muscovite-bearing samples and biotite ages were also calculated from seven of these samples. Biotite was analyzed from one sample without muscovite. Most of these samples were collected within $5 \mathrm{~km}$ of the detachment. Hornblende was only analyzed from one sample (18ET177) approximately $16 \mathrm{~km}$ south of the detachment and hornblende was not present in the rocks collected near the detachment.

Thin section descriptions in Naibert and others (2020) suggest the mica in each of these samples represent a single generation, as mica grain size and texture are consistent within each thin section. Micas define the foliation in all samples except the amphibolite sample 18ET177. Muscovite appears largely unaltered since formation. Biotite is commonly partially to completely chloritized but does not appear to be recrystallized. In a few samples, biotite was observed surrounding garnet, and could have crystallized as a replacement of garnet under upper-greenschist/ lower-amphibolite retrograde conditions, but this biotite has similar color and pleochroism to the rest of the biotite in the thin section, suggesting formation under similar metamorphic conditions.

Hornblende is more abundant in the Fortymile River assemblage in the southeast Eagle Quadrangle, possibly due to more varied protoliths existing in that area, and ${ }^{40} \mathrm{Ar} /{ }^{39} \mathrm{Ar}$ and $\mathrm{K}-\mathrm{Ar}$ horn-

${ }^{1}$ Alaska Division of Geological \& Geophysical Surveys, 3354 College Rd., Fairbanks, Alaska 99709-3707.

2University of Alaska Fairbanks Geochronology Laboratory, P.O. Box 755940, Fairbanks, AK 99775-5940. 
blende ages reported in Hansen and others (1991), Dusel-Bacon and others (2002), and Wilson and others (2015) are included in our interpretation. Most of these hornblende ages are from 20 to 35 $\mathrm{km}$ north of the detachment, though hornblende has been dated just south of the detachment at two locations. Locations of muscovite and biotite age samples range from $15 \mathrm{~km}$ south of the detachment to $35 \mathrm{~km}$ north of the detachment. Previously published ${ }^{40} \mathrm{Ar} /{ }^{39} \mathrm{Ar}$ ages used in this study include total fusion, isochron, and plateau ages. $\mathrm{K}$-Ar ages are analogous to total fusions ages.

We calculated argon diffusion closure temperatures for biotite and hornblende using the CLOSURE program of Brandon and others (1998) assuming a grain size of $100 \mu \mathrm{m}$ and a range of cooling rates of $5-25^{\circ} \mathrm{C} /$ million years (m.y.). The CLOSURE program applies diffusion parameters given in Grove and Harrison (1996; for biotite) and Harrison (1981; for hornblende). The calculated closure temperature for biotite is $304 \pm 11^{\circ} \mathrm{C}$ and the estimated closure temperature for hornblende is 495 $\pm 14^{\circ} \mathrm{C}$. We use an argon diffusion closure temperature of $410 \pm 15^{\circ} \mathrm{C}$ for muscovite for a grain size of $100 \mu \mathrm{m}$ and a range of cooling rates of $5-25^{\circ} \mathrm{C} / \mathrm{m}$.y. as shown in Harrison and others (2009).

\section{RESULTS}

\section{Allochthonous Fortymile River Assemblage}

Four muscovite cooling ages in the Fortymile River assemblage within $6 \mathrm{~km}$ of the Fortymile River-Lake George detachment (17ET038, 18MBW399, 18RN122, 18RN358; fig. 1, table 1) range from 163.9 to $149.4 \mathrm{Ma}$ (Naibert and others, 2020). The step-heating spectra for muscovite from the Fortymile River assemblage are generally flat. Weighted-average ages were calculated for two of the samples without appropriate plateaus. None of these Fortymile River muscovite samples had younger ages for lower-temperature steps, and there are no indications of alteration or argon loss from a younger thermal event after cooling from peak metamorphic temperatures. Both biotite and muscovite ages were measured for sample 18RN358. The biotite step-heating spectrum has a hump shape with younger ages from the lowest and highest-temperature heating steps. A plateau age of $96.4 \mathrm{Ma}$ was calculated from the intermediate-temperature heating steps, which is unlike other ages in the map area. We do not interpret this age as a reliable cooling age for the Fortymile River assemblage due to 1) the high atmospheric content and low radiogenic argon content of all heating steps in the sample, and 2) the lack of similarity to other sample ages. Sample 18RN358 was collected within $3 \mathrm{~km}$ of Late Cretaceous volcanic rocks and the biotite age could have been partially reset by unexposed intrusions of this age.

A $145.5 \mathrm{Ma}{ }^{40} \mathrm{Ar} /{ }^{39} \mathrm{Ar}$ muscovite age for sample 16-YTT-30 (Jones and Benowitz, 2020) from approximately $10 \mathrm{~km}$ north of the detachment is similar to the ages reported by Naibert and others (2020). A 165.6 Ma biotite age from $3 \mathrm{~km}$ north of the detachment (sample 90ADb17A) was previously interpreted by Dusel-Bacon and others (2002) to be Lake George assemblage or from within the detachment zone itself, but we reinterpret that sample to be part of the Fortymile River assemblage based on lithologic observations in the immediate vicinity that more closely match other Fortymile River assemblage rocks in the map area. The within-plate chemistry of nearby amphibolite previously used by Dusel-Bacon and others (2002) to assign the sample to the Lake George assemblage has not proven to be unique to Lake George amphibolites (Wypych and others, 2017; Wypych and others, 2018). Mica cooling ages reported by Flynn (2003) are similar to those reported by Naibert and others (2020), but hornblende ages reported by Flynn are more similar to the cooling ages along the Taylor Highway (discussed below).

Two ${ }^{40} \mathrm{Ar} /{ }^{39} \mathrm{Ar}$ samples from rocks mapped by Wypych and others (2021) as Fortymile River assemblage have Cretaceous cooling ages (fig. 1). The cooling age for biotite from sample 18MLW 132 is $123.9 \mathrm{Ma}$, which is only slightly older than Lake George assemblage samples (discussed below) and 


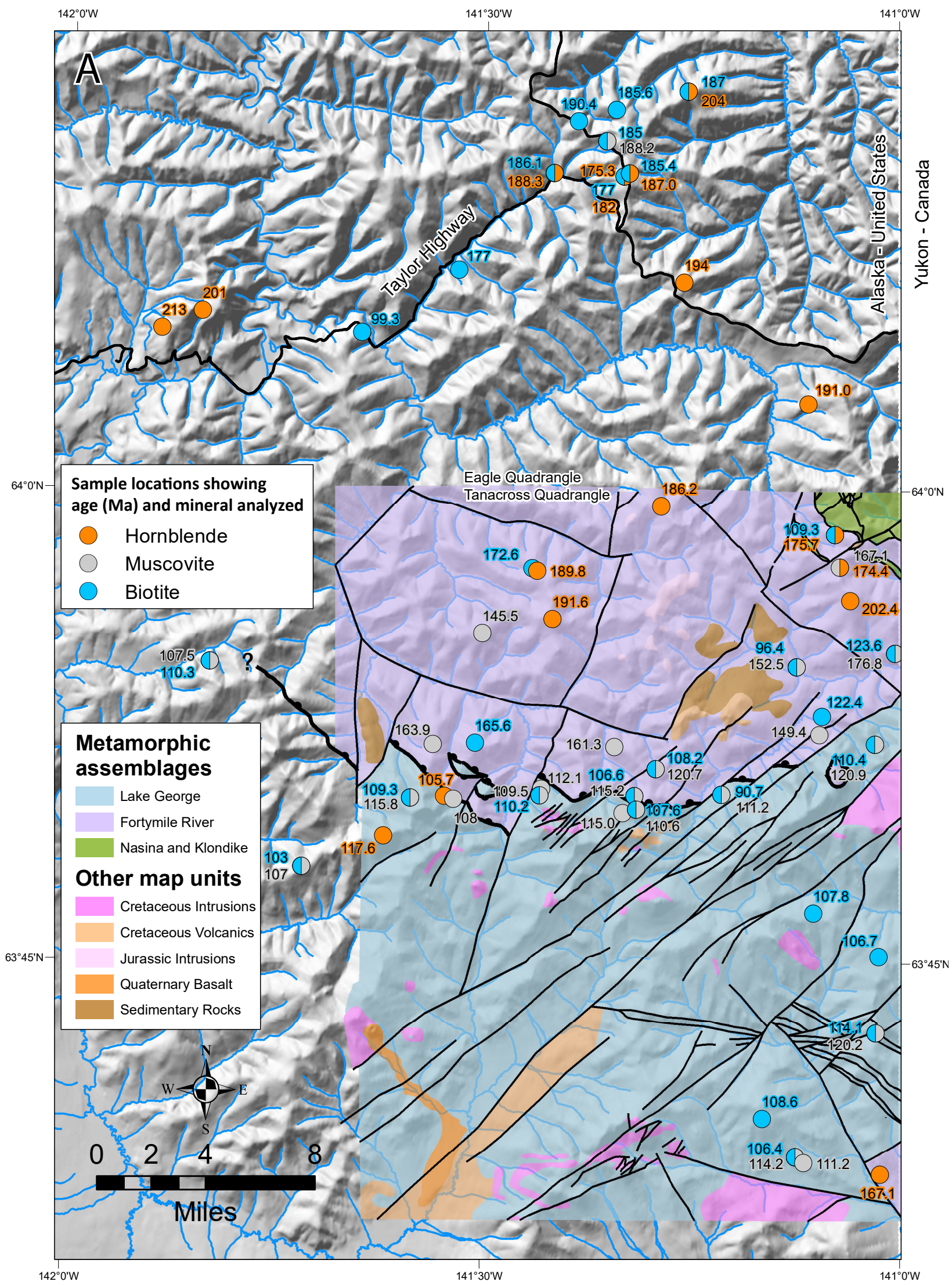

Figure 1A. Location of ${ }^{40} \mathrm{Ar} /{ }^{39} \mathrm{Ar}$ and $\mathrm{K}-\mathrm{Ar}$ cooling ages in the northeast Tanacross Quadrangle and southeast Eagle Quadrangle. Map units and faults are from Wypych and others (2021), including the position of the Fortymile River-Lake George detachment (thick line with teeth on hanging wall). 


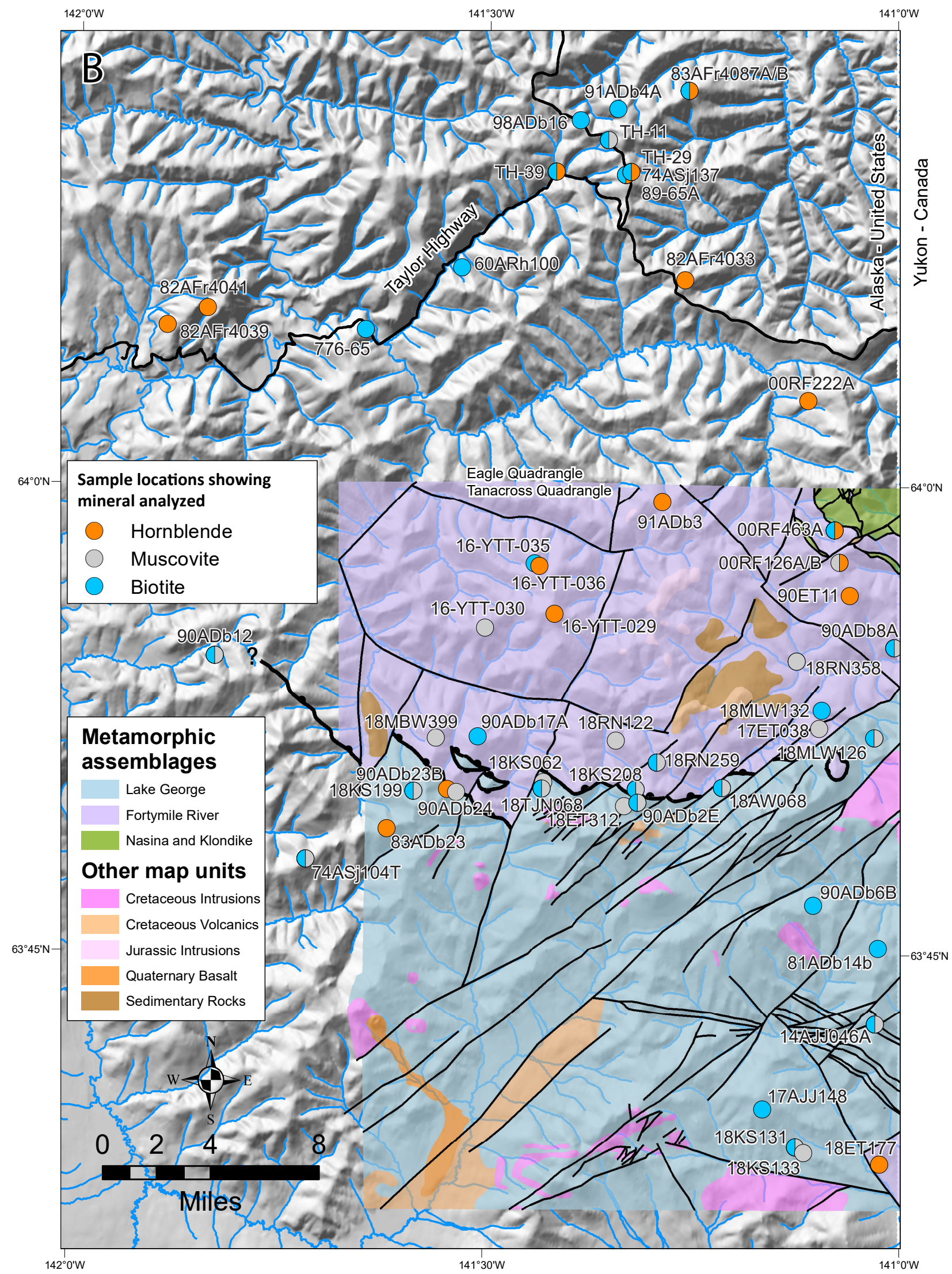

Figure 1B. Sample numbers in the northeast Tanacross Quadrangle and southeast Eagle Quadrangle. Map units and faults are from Wypych and others (2021), including the position of the Fortymile River-Lake George detachment (thick line with teeth on hanging wall). 
Table 1. ${ }^{40} \mathrm{Ar} /{ }^{39} \mathrm{Ar}$ and $\mathrm{K}$-Ar age data in the northeast Tanacross and southeast Eagle quadrangles from metamorphic samples in the Fortymile River and Lake George assemblages. Reported ages are preferred ages with 1-sigma uncertainty. Locations are in the WGS84 datum. Distance (m) is map distance to the Fortymile River-Lake George detachment.

\begin{tabular}{|c|c|c|c|c|c|c|c|c|c|}
\hline Sample & Mineral & $\begin{array}{l}\text { Dating } \\
\text { Method }\end{array}$ & Age Type & Age & Assemblage & $\begin{array}{l}\text { Latitude } \\
\text { WGS84 }\end{array}$ & $\begin{array}{l}\text { Longitude } \\
\text { WGS84 }\end{array}$ & $\begin{array}{l}\text { Distance } \\
(\mathrm{m})\end{array}$ & Source \\
\hline O0RF126A & Muscovite & ${ }^{40} \mathrm{Ar} /{ }^{39} \mathrm{Ar}$ & integrated & $167.1 \pm 0.8$ & Fortymile River & 63.95964467 & -141.0719656 & 12161 & Flynn, 2003 \\
\hline 00RF126B & Hornblende & ${ }^{40} \mathrm{Ar} /{ }^{39} \mathrm{Ar}$ & plateau & $174.4 \pm 3.2$ & Fortymile River & 63.95964426 & -141.0727822 & 12161 & Flynn, 2003 \\
\hline OORF222A & hornblende & ${ }^{40} \mathrm{Ar} /{ }^{39} \mathrm{Ar}$ & plateau & $191.0 \pm 1.6$ & Fortymile River & 64.046217 & -141.110096 & 21930 & Flynn, 2003 \\
\hline OORF463A & Biotite & ${ }^{40} \mathrm{Ar} /{ }^{39} \mathrm{Ar}$ & plateau & $109.3 \pm 0.6$ & Fortymile River & 63.97706972 & -141.0776282 & 14113 & Flynn, 2003 \\
\hline OORF463A & Hornblende & ${ }^{40} \mathrm{Ar} /{ }^{39} \mathrm{Ar}$ & plateau & $175.7 \pm 1.6$ & Fortymile River & 63.97706972 & -141.0776282 & 14113 & Flynn, 2003 \\
\hline 16-YTT-029 & hornblende & ${ }^{40} \mathrm{Ar} /{ }^{39} \mathrm{Ar}$ & plateau & $191.6 \pm 1.5$ & Fortymile River & 63.93196 & -141.4174 & 9256 & Jones, written communication, 2018; Jones and others, 2017 \\
\hline $16-Y T T-030$ & muscovite & ${ }^{40} \mathrm{Ar} / 39 \mathrm{Ar}$ & weighted average & $145.5 \pm 1.1$ & Fortymile River & 63.92421 & -141.50203 & 8313 & Jones, written communication, 2018; Jones and others, 2017 \\
\hline $16-Y T T-035$ & hornblende & ${ }^{40} \mathrm{Ar} /{ }^{39} \mathrm{Ar}$ & plateau & $189.8 \pm 1.3$ & Fortymile River & 63.95756 & -141.43656 & 12066 & Jones, written communication, 2018; Jones and others, 2017 \\
\hline $16-$ YTT-036 & biotite & ${ }^{40} \mathrm{Ar} /{ }^{39} \mathrm{Ar}$ & plateau & $172.6 \pm 0.7$ & Fortymile River & 63.95889 & -141.44202 & 12218 & Jones, written communication, 2018; Jones and others, 2017 \\
\hline 17ЕT038 & Muscovite & ${ }^{40} \mathrm{Ar} /{ }^{39} \mathrm{Ar}$ & weighted average & $149.4 \pm 2.0$ & Fortymile River & 63.871074 & -141.09595 & 1482 & Naibert and others, 2020 \\
\hline 18ET177 & Hornblende & ${ }^{40} \mathrm{Ar} /{ }^{39} \mathrm{Ar}$ & weighted average & $167.1 \pm 2.7$ & Fortymile River & 63.638082 & -141.023323 & 23706 & Naibert and others, 2020 \\
\hline 18MBW399 & Muscovite & ${ }^{40} \mathrm{Ar} /{ }^{39} \mathrm{Ar}$ & plateau & $163.9 \pm 2.7$ & Fortymile River & 63.865231 & -141.560388 & 1452 & Naibert and others, 2020 \\
\hline 18MLW132 & Biotite & ${ }^{40} \mathrm{Ar} /{ }^{39} \mathrm{Ar}$ & weighted average & $122.4 \pm 2.1$ & Fortymile River & 63.880768 & -141.092841 & 2419 & Naibert and others, 2020 \\
\hline 18RN122 & Muscovite & ${ }^{40} \mathrm{Ar} /{ }^{39} \mathrm{Ar}$ & plateau & $161.3 \pm 2.9$ & Fortymile River & 63.864276 & -141.342487 & 2490 & Naibert and others, 2020 \\
\hline 18RN259 & Biotite & ${ }^{40} \mathrm{Ar} /{ }^{39} \mathrm{Ar}$ & weighted average & $108.2 \pm 3.0$ & Fortymile River & 63.852687 & -141.292813 & 1970 & Naibert and others, 2020 \\
\hline 18RN259 & Muscovite & ${ }^{40} \mathrm{Ar} /{ }^{39} \mathrm{Ar}$ & plateau & $120.7 \pm 2.0$ & Fortymile River & 63.852687 & -141.292813 & 1970 & Naibert and others, 2020 \\
\hline 18RN358 & Biotite & ${ }^{40} \mathrm{Ar} /{ }^{39} \mathrm{Ar}$ & plateau & $96.4 \pm 2.3$ & Fortymile River & 63.90686 & -141.123432 & 5662 & Naibert and others, 2020 \\
\hline 18RN358 & Muscovite & ${ }^{40} \mathrm{Ar} /{ }^{39} \mathrm{Ar}$ & plateau & $152.5 \pm 1.9$ & Fortymile River & 63.90686 & -141.123432 & 5662 & Naibert and others, 2020 \\
\hline 60ACh100 & biotite & $\mathrm{K}-\mathrm{Ar}$ & & 177 & Fortymile River & 64.116667 & -141.533333 & 26425 & Wilson and others, 2015 \\
\hline 74ASj137 & biotite & $\mathrm{K}-\mathrm{Ar}$ & & $177 \pm 5$ & Fortymile River & 64.166667 & -141.333333 & 35805 & Wilson and others, 2015 \\
\hline 74ASj137 & hornblende & $\mathrm{K}-\mathrm{Ar}$ & & 182 & Fortymile River & 64.166667 & -141.333333 & 35805 & Wilson and others, 2015 \\
\hline $776-65$ & biotite & $\mathrm{K}-\mathrm{Ar}$ & & $99.3 \pm 3$ & Fortymile River & 64.083333 & -141.65 & 20676 & Wilson and others, 2015 \\
\hline $82 \mathrm{AFr} 4033$ & hornblende & ${ }^{40} \mathrm{Ar} /{ }^{39} \mathrm{Ar}$ & plateau & $194 \pm 2$ & Fortymile River & 64.110667 & -141.260667 & 29422 & Wilson and others, 2015 \\
\hline 82AFr4039 & hornblende & ${ }^{40} \mathrm{Ar} /{ }^{39} \mathrm{Ar}$ & plateau & $213 \pm 2$ & Fortymile River & 64.084667 & -141.892167 & 15529 & Wilson and others, 2015 \\
\hline $82 \mathrm{AFr} 4041$ & Hornblende & ${ }^{40} \mathrm{Ar} /{ }^{39} \mathrm{Ar}$ & plateau & $201 \pm 5$ & Fortymile River & 64.094167 & -141.843333 & 17541 & Wilson and others, 2015 \\
\hline
\end{tabular}


Table 1, continued. ${ }^{40} \mathrm{Ar} /{ }^{39} \mathrm{Ar}$ and $\mathrm{K}$-Ar age data in the northeast Tanacross and southeast Eagle quadrangles from metamorphic samples in the Fortymile River and Lake George assemblages. Reported ages are preferred ages with 1-sigma uncertainty. Locations are in the WGS84 datum. Distance (m) is map distance to the Fortymile RiverLake George detachment.

\begin{tabular}{|c|c|c|c|c|c|c|c|c|c|}
\hline Sample & Mineral & $\begin{array}{l}\text { Dating } \\
\text { Method }\end{array}$ & Age Type & Age & Assemblage & $\begin{array}{l}\text { Latitude } \\
\text { WGS84 }\end{array}$ & $\begin{array}{c}\text { Longitude } \\
\text { WGS84 }\end{array}$ & $\begin{array}{c}\text { Distance } \\
(\mathrm{m})\end{array}$ & Source \\
\hline 83AFr4087A & hornblende & ${ }^{40} \mathrm{Ar}{ }^{39} \mathrm{Ar}$ & plateau & $204 \pm 4$ & Fortymile River & 64.211833 & -141.256 & 40681 & Wilson and others, 2015 \\
\hline 83AFr4087B & biotite & ${ }^{40} \mathrm{Ar} /{ }^{39} \mathrm{Ar}$ & plateau & $187 \pm 2$ & Fortymile River & 64.211833 & -141.256 & 40681 & Wilson and others, 2015 \\
\hline $89-65 A$ & hornblende & $\mathrm{K}-\mathrm{Ar}$ & & $175.3 \pm 5.1$ & Fortymile River & 64.166667 & -141.333333 & 35805 & Wilson and others, 2015 \\
\hline 90ADb17A & Biotite & ${ }^{40} \mathrm{Ar} /{ }^{39} \mathrm{Ar}$ & weighted average & $165.6 \pm 0.8$ & Fortymile River & 63.866167 & -141.5095 & 2960 & Dusel-Bacon and others, 2002 \\
\hline 90ADb8A & Biotite & ${ }^{40} \mathrm{Ar} /{ }^{39} \mathrm{Ar}$ & weighted average & $123.6 \pm 0.7$ & Fortymile River & 63.914167 & -141.005333 & 7009 & Dusel-Bacon and others, 2002 \\
\hline 90ADb8A & Muscovite & ${ }^{40} \mathrm{Ar} /{ }^{39} \mathrm{Ar}$ & platuea & $176.8 \pm 0.9$ & Fortymile River & 63.914167 & -141.005333 & 7009 & Dusel-Bacon and others, 2002 \\
\hline 90ET11 & hornblende & ${ }^{40} \mathrm{Ar}{ }^{39} \mathrm{Ar}$ & total fusion & $202.4 \pm 1.6$ & Fortymile River & 63.942 & -141.059 & 9205 & Dusel-Bacon and others, 2002 \\
\hline 91ADb3 & hornblende & ${ }^{40} \mathrm{Ar} /{ }^{39} \mathrm{Ar}$ & total fusion & $186.2 \pm 1.3$ & Fortymile River & 63.992 & -141.287167 & 16257 & Dusel-Bacon and others, 2002 \\
\hline 91ADb4A & biotite & ${ }^{40} \mathrm{Ar}{ }^{39} \mathrm{Ar}$ & total fusion & $185.6 \pm 0.4$ & Fortymile River & 64.202 & -141.343333 & 39187 & Dusel-Bacon and others, 2002 \\
\hline 98ADb16 & biotite & ${ }^{40} \mathrm{Ar}{ }^{39} \mathrm{Ar}$ & plateau & $190.4 \pm 1.8$ & Fortymile River & 64.195833 & -141.389167 & 37573 & Dusel-Bacon and others, 2002 \\
\hline TH-11 & biotite & ${ }^{40} \mathrm{Ar} /{ }^{39} \mathrm{Ar}$ & isochron & $188.2 \pm 1.0$ & Fortymile River & 64.1852 & -141.3548 & 37264 & Hansen and others, 1991 \\
\hline TH-11 & muscovite & ${ }^{40} \mathrm{Ar}{ }^{39} \mathrm{Ar}$ & isochron & $185.0 \pm 0.6$ & Fortymile River & 64.1852 & -141.3548 & 37264 & Hansen and others, 1991 \\
\hline $\mathrm{TH}-29$ & biotite & ${ }^{40} \mathrm{Ar}{ }^{39} \mathrm{Ar}$ & isochron & $185.4 \pm 0.3$ & Fortymile River & 64.1682 & -141.327 & 35963 & Hansen and others, 1991 \\
\hline TH-29 & hornblende & ${ }^{40} \mathrm{Ar} /{ }^{39} \mathrm{Ar}$ & isochron & $187.0 \pm 0.2$ & Fortymile River & 64.1682 & -141.327 & 35963 & Hansen and others, 1991 \\
\hline TH-39 & biotite & ${ }^{40} \mathrm{Ar} /{ }^{39} \mathrm{Ar}$ & isochron & $186.1 \pm 1.0$ & Fortymile River & 64.1682 & -141.4185 & 34180 & Hansen and others, 1991 \\
\hline TH-39 & hornblende & ${ }^{40} \mathrm{Ar}{ }^{39} \mathrm{Ar}$ & isochron & $188.3 \pm 0.3$ & Fortymile River & 64.1682 & -141.4185 & 34180 & Hansen and others, 1991 \\
\hline 14AJJ046A & biotite & ${ }^{40} \mathrm{Ar} /{ }^{39} \mathrm{Ar}$ & isochron & $120.2 \pm 0.8$ & Lake George & 63.71301 & -141.0285 & 15350 & Jones, written communication, 2018; Jones and others, 2017 \\
\hline 14AJJ046A & Muscovite & ${ }^{40} \mathrm{Ar} /{ }^{39} \mathrm{Ar}$ & plateau & $114.1 \pm 1.1$ & Lake George & 63.71301 & -141.0285 & 15350 & Jones, written communication, 2018; Jones and others, 2017 \\
\hline 17AJJ148 & Biotite & ${ }^{40} \mathrm{Ar} /{ }^{39} \mathrm{Ar}$ & plateau & $108.6 \pm 1.0$ & Lake George & 63.667571 & -141.164124 & 20127 & Jones, written communication, 2018; Jones and others, 2017 \\
\hline 18AW068 & Biotite & ${ }^{40} \mathrm{Ar} /{ }^{39} \mathrm{Ar}$ & plateau & $90.7 \pm 2.0$ & Lake George & 63.839244 & -141.213635 & 934 & Naibert and others, 2020 \\
\hline 18AW068 & Muscovite & ${ }^{40} \mathrm{Ar} /{ }^{39} \mathrm{Ar}$ & plateau & $111.2 \pm 1.4$ & Lake George & 63.839244 & -141.213635 & 934 & Naibert and others, 2020 \\
\hline $18 \mathrm{ET} 312$ & Muscovite & ${ }^{40} \mathrm{Ar} /{ }^{39} \mathrm{Ar}$ & plateau & $115.0 \pm 1.5$ & Lake George & 63.829381 & -141.331759 & 831 & Naibert and others, 2020 \\
\hline $18 \mathrm{KS} 062$ & Muscovite & ${ }^{40} \mathrm{Ar} /{ }^{39} \mathrm{Ar}$ & plateau & $112.1 \pm 1.6$ & Lake George & 63.841915 & -141.429834 & 587 & Naibert and others, 2020 \\
\hline
\end{tabular}


Table 1, continued. ${ }^{40} \mathrm{Ar} /{ }^{39} \mathrm{Ar}$ and $\mathrm{K}$-Ar age data in the northeast Tanacross and southeast Eagle quadrangles from metamorphic samples in the Fortymile River and Lake George assemblages. Reported ages are preferred ages with 1-sigma uncertainty. Locations are in the WGS84 datum. Distance (m) is map distance to the Fortymile RiverLake George detachment.

\begin{tabular}{|c|c|c|c|c|c|c|c|c|c|}
\hline Sample & Mineral & $\begin{array}{l}\text { Dating } \\
\text { Method }\end{array}$ & Age Type & Age & Assemblage & $\begin{array}{l}\text { Latitude } \\
\text { WGS84 }\end{array}$ & $\begin{array}{l}\text { Longitude } \\
\text { WGS84 }\end{array}$ & $\begin{array}{l}\text { Distance } \\
\text { (m) }\end{array}$ & Source \\
\hline 18KS131 & Biotite & ${ }^{40} \mathrm{Ar}{ }^{39} \mathrm{Ar}$ & weighted average & $106.4 \pm 0.3$ & Lake George & 63.647391 & -141.124253 & 22460 & Naibert and others, 2020 \\
\hline 18KS131 & Muscovite & ${ }^{40} \mathrm{Ar} /{ }^{39} \mathrm{Ar}$ & plateau & $114.2 \pm 2.9$ & Lake George & 63.647391 & -141.124253 & 22460 & Naibert and others, 2020 \\
\hline 18KS133 & Muscovite & ${ }^{40} \mathrm{Ar} /{ }^{39} \mathrm{Ar}$ & plateau & $111.2 \pm 1.7$ & Lake George & 63.644343 & -141.114449 & 22820 & Naibert and others, 2020 \\
\hline 18KS199 & Biotite & ${ }^{40} \mathrm{Ar} /{ }^{39} \mathrm{Ar}$ & plateau & $109.3 \pm 1.3$ & Lake George & 63.836759 & -141.58707 & 1716 & Naibert and others, 2020 \\
\hline 18KS199 & Muscovite & ${ }^{40} \mathrm{Ar} /{ }^{39} \mathrm{Ar}$ & plateau & $115.8 \pm 3.0$ & Lake George & 63.836759 & -141.58707 & 1716 & Naibert and others, 2020 \\
\hline 18KS208 & Biotite & ${ }^{40} \mathrm{Ar} /{ }^{39} \mathrm{Ar}$ & weighted average & $106.6 \pm 1.4$ & Lake George & 63.838378 & -141.317977 & 24 & Naibert and others, 2020 \\
\hline 18KS208 & Muscovite & ${ }^{40} \mathrm{Ar} /{ }^{39} \mathrm{Ar}$ & plateau & $115.2 \pm 2.0$ & Lake George & 63.838378 & -141.317977 & 24 & Naibert and others, 2020 \\
\hline 18MLW126 & Biotite & ${ }^{40} \mathrm{Ar} /{ }^{39} \mathrm{Ar}$ & plateau & $110.4 \pm 2.1$ & Lake George & 63.8659 & -141.029008 & 2207 & Naibert and others, 2020 \\
\hline $18 M L W 126$ & Muscovite & ${ }^{40} \mathrm{Ar} /{ }^{39} \mathrm{Ar}$ & plateau & $120.9 \pm 1.4$ & Lake George & 63.8659 & -141.029008 & 2207 & Naibert and others, 2020 \\
\hline 18TJN068 & Biotite & ${ }^{40} \mathrm{Ar} /{ }^{39} \mathrm{Ar}$ & plateau & $110.2 \pm 2.1$ & Lake George & 63.838531 & -141.431765 & 947 & Naibert and others, 2020 \\
\hline 18TJN068 & Muscovite & ${ }^{40} \mathrm{Ar} /{ }^{39} \mathrm{Ar}$ & plateau & $109.5 \pm 1.8$ & Lake George & 63.838531 & -141.431765 & 947 & Naibert and others, 2020 \\
\hline 74ASj104T & biotite & $\mathrm{K}-\mathrm{Ar}$ & & 103 & Lake George & 63.8 & -141.716667 & 6554 & Wilson and others, 2015 \\
\hline 74ASj104T & Muscovite & $\mathrm{K}-\mathrm{Ar}$ & & 107 & Lake George & 63.8 & -141.716667 & 6554 & Wilson and others, 2015 \\
\hline 81ADb14b & biotite & $\mathrm{K}-\mathrm{Ar}$ & & 106.7 & Lake George & 63.753333 & -141.025 & 10440 & Wilson and others, 2015 \\
\hline 83ADb23 & Hornblende & ${ }^{40} \mathrm{Ar} /{ }^{39} \mathrm{Ar}$ & weighted average & $117.6 \pm 1.2$ & Lake George & 63.816667 & -141.618833 & 4209 & Dusel-Bacon and others, 2002 \\
\hline 90ADb12 & biotite & ${ }^{40} \mathrm{Ar} /{ }^{39} \mathrm{Ar}$ & plateau & $110.3 \pm 1.1$ & Lake George & 63.908333 & -141.829167 & 2736 & Dusel-Bacon and others, 2002 \\
\hline 90ADb12 & Muscovite & ${ }^{40} \mathrm{Ar} /{ }^{39} \mathrm{Ar}$ & plateau & $107.5 \pm 0.6$ & Lake George & 63.908333 & -141.829167 & 2736 & Dusel-Bacon and others, 2002 \\
\hline 90ADb23B & Hornblende & ${ }^{40} \mathrm{Ar} /{ }^{39} \mathrm{Ar}$ & total fusion & $105.7 \pm 1.3$ & Lake George & 63.837833 & -141.546333 & 3 & Dusel-Bacon and others, 2002 \\
\hline 90ADb24 & Muscovite & ${ }^{40} \mathrm{Ar} /{ }^{39} \mathrm{Ar}$ & total fusion & $108 \pm 0.3$ & Lake George & 63.836333 & -141.535333 & 7 & Dusel-Bacon and others, 2002 \\
\hline 90ADb2E & Biotite & ${ }^{40} \mathrm{Ar} /{ }^{39} \mathrm{Ar}$ & total fusion & $107.6 \pm 0.3$ & Lake George & 63.831167 & -141.315833 & 522 & Dusel-Bacon and others, 2002 \\
\hline 90ADb2E & Muscovite & ${ }^{40} \mathrm{Ar} /{ }^{39} \mathrm{Ar}$ & total fusion & $110.6 \pm 0.7$ & Lake George & 63.831167 & -141.315833 & 522 & Dusel-Bacon and others, 2002 \\
\hline 90ADb6B & Biotite & ${ }^{40} \mathrm{Ar} /{ }^{39} \mathrm{Ar}$ & total fusion & $107.8 \pm 0.3$ & Lake George & 63.776333 & -141.103333 & 7685 & Dusel-Bacon and others, 2002 \\
\hline
\end{tabular}


significantly younger than other Fortymile River assemblage samples. Biotite in sample 18MLW132 is interpreted as primary biotite, though biotite observed in thin section around garnet grains could potentially be secondary. Similar color and pleochroism suggest that all biotite formed under similar conditions and cooled at the same time. Cooling ages of 120.7 Ma for muscovite and 108.2 Ma for biotite from sample 18RN259 are also similar to Lake George assemblage cooling ages. Both of these samples were collected along ridges composed primarily of metasedimentary unitsincluding graphitic quartzite-that most closely resemble rocks of the Fortymile River assemblage. Age spectra for biotite separates from both samples stepped up to older ages at higher heating steps. The highest heating steps record ages of $129 \mathrm{Ma}$ for 18MLW132 (represented by over 50 percent of the argon released) and $125 \mathrm{Ma}$ for $18 \mathrm{RN} 259$, which predate Lake George cooling, post-date Fortymile River cooling, and might indicate bulk argon loss after initial cooling. We continue to interpret these samples as Fortymile River assemblage based on their similarities with other lithologies common to the assemblage.

A biotite age of 109.3 Ma from a biotite-hornblendite sample in the Fortymile River assemblage was interpreted as the age of a thermal resetting event by Flynn (2003). The thermal resetting event may be related to mid-Cretaceous intrusions and pegmatite dikes in the area. Hornblende from the same sample has a cooling age of $175.7 \mathrm{Ma}$ and is similar to other cooling ages in the Fortymile River assemblage. A K-Ar biotite age of $99.3 \mathrm{Ma}$ from sample 776-65 (Wilson and others, 2015) is also significantly younger than other nearby Fortymile River cooling ages and we do not consider the age to be a reliable cooling age.

A cooling age for hornblende from sample 18 ET177 is $167.1 \mathrm{Ma}$. The sample is from an amphibolite collected in the southeastern corner of the Northeast Tanacross map area (fig. 1). Abundant actinolite was observed in thin section, indicating that the sample has undergone incom- plete retrograde greenschist-grade metamorphism of hornblende to actinolite. High $\mathrm{Ca} / \mathrm{K}$ ratios in high-temperature heating steps used for the weighted-average age indicate the ${ }^{40} \mathrm{Ar} /{ }^{39} \mathrm{Ar}$ age may be from the retrograde actinolite, a Ca-rich amphibole. We interpret this sample to be from the allochthonous Yukon Tanana terrane and not from the Lake George assemblage as the cooling age is significantly older than Lake George assemblage cooling ages. If the sample is from the Fortymile River assemblage it suggests that the detachment is folded or faulted and that hanging wall rocks are exposed in the area south of the northeast Tanacross map of Wypych and other (2021). This is supported by mapped allochthonous rocks with cooling ages greater than $200 \mathrm{Ma}$ (Jones and others, 2017) in the area around the Ladue River in the eastern Tanacross Quadrangle and across the international border in Yukon.

\section{Parautochthonous Lake George Assemblage}

Seven cooling ages for muscovite from Lake George assemblage samples (18AW068, 18ET312, 18KS062, 18KS199, 18KS208, 18MLW126, 18TJN068; fig. 1) from within $5 \mathrm{~km}$ (map view) of the Fortymile River-Lake George detachment range from 120.9 to $109.5 \mathrm{Ma}$ (Naibert and others, 2020). Biotite cooling ages from four of these samples (18KS199, 18KS208, 18MLW126, 18TJN068) range from 110.4 to $106.6 \mathrm{Ma}$. Muscovite from sample 18TJN068 yielded a younger cooling age than biotite from the same sample, but the ages are within analytical error. The other three samples have younger biotite ages than muscovite ages, as expected based the difference in estimated closure temperatures of biotite $\left(304 \pm 11^{\circ} \mathrm{C}\right)$ and muscovite $\left(410 \pm 15^{\circ} \mathrm{C}\right)$.

Two samples (18KS131, 18KS133) with muscovite cooling ages of 114.2 and 111.2 Ma were collected from Lake George assemblage schist and orthogneiss about $20 \mathrm{~km}$ south of the Fortymile River-Lake George detachment. A biotite age of 106.4 Ma was also measured for sample 18KS131. 
These ages are similar to other Early Cretaceous ages for the Lake George assemblage reported by Dusel-Bacon and others (2002) and Jones and Benowitz (2020).

A $90.7 \mathrm{Ma}{ }^{40} \mathrm{Ar} /{ }^{39} \mathrm{Ar}$ biotite age from Lake George assemblage sample 18AW068 is 15 m.y. younger than other Lake George assemblage biotite samples and over 20 m.y. younger than muscovite from the same location. The age spectrum has young ages at lower heating steps, indicating that a younger alteration or argon loss event affected the biotite after initial cooling. Chlorititic alteration of biotite and minor epidote were observed in thin section, indicating the sample experienced some retrograde greenschist-grade metamorphism. The age spectrum does have an acceptable age plateau over the highest heating steps. It is possible that the age and shape of the age spectrum resulted from argon loss during retrograde metamorphism, due to unidentified fluid flow along the nearby Fortymile River-Lake George detachment, or due to unidentified magmatic activity nearby. We hesitate to interpret the $90.7 \mathrm{Ma}$ age as a cooling age for the Lake George assemblage from amphibolite-facies temperatures because it is so much younger than nearby samples.

\section{DISCUSSION}

Both the Lake George and Fortymile River assemblages are interpreted by Dusel-Bacon and others (2002) to have reached amphibolite facies metamorphism at temperatures above the ${ }^{40} \mathrm{Ar} /{ }^{39} \mathrm{Ar}$ closure temperatures of muscovite, biotite, and hornblende, which resulted in diffusive loss of radiogenic argon produced prior to cooling. It is therefore appropriate to interpret data from all three minerals as post-metamorphic cooling ages for the Fortymile River and Lake George assemblages (Warren and others, 2012). Post-cooling neocrystallization of micas is not indicated by the petrographic descriptions in Naibert and others (2020). Dusel-Bacon and others (2002) ascribed ${ }^{40} \mathrm{Ar} /{ }^{39} \mathrm{Ar}$ ages in the Fortymile River assemblage (between 191 and $185 \mathrm{Ma}$ ) to rock uplift during northwest-directed thrusting of the allochthon over North American continental-margin rocks of the Lake George assemblage during the Late Triassic to Early Jurassic. They attribute younger cooling ages (between 120 and $108 \mathrm{Ma}$ ) in the Lake George assemblage to a southeast-directed extensional event that caused footwall exhumation below a shallow-dipping ductile detachment. Structural data presented by Hansen and DuselBacon (1998) support this two-stage model of thrusting followed by extension in the Fortymile River and Lake George assemblages in the northeast Tanacross Quadrangle.

${ }^{40} \mathrm{Ar} /{ }^{39} \mathrm{Ar}$ ages presented in Naibert and others (2020) are also interpreted to record cooling following amphibolite facies metamorphism. Consistent with results from Dusel-Bacon and others (2002), the ${ }^{40} \mathrm{Ar} /{ }^{39} \mathrm{Ar}$ ages presented in Naibert and others (2020) indicate that the Fortymile River and Lake George assemblages cooled at different times and rates. However, they differ in that Fortymile River samples within $10 \mathrm{~km}$ (map view) of the detachment are 20-40 m.y. younger than Fortymile River samples reported by Dusel-Bacon and others (2002) from $20-35 \mathrm{~km}$ north of the detachment. Cooling ages in the Fortymile River assemblage previously reported by Hansen and others (1991), Dusel-Bacon and others (2002), and Wilson and others (2015) were mostly from samples collected along the Taylor Highway in the Eagle Quadrangle (fig. 1). These locations are $20-35 \mathrm{~km}$ north of the detachment and have cooling ages 20-40 m.y. older than cooling ages from samples collected closer to the Fortymile River-Lake George detachment reported by Naibert and others (2020). Figure 2 shows these geographical differences in cooling ages from within $20 \mathrm{~km}$ of the detachment and cooling ages from more than 20 $\mathrm{km}$ from the detachment along the Taylor Highway.

\section{Fortymile River Assemblage}

Cooling rates and exhumation rates can be calculated for samples with cooling ages from multiple minerals that have different argon closure temperatures. Hornblende and biotite ages from samples 


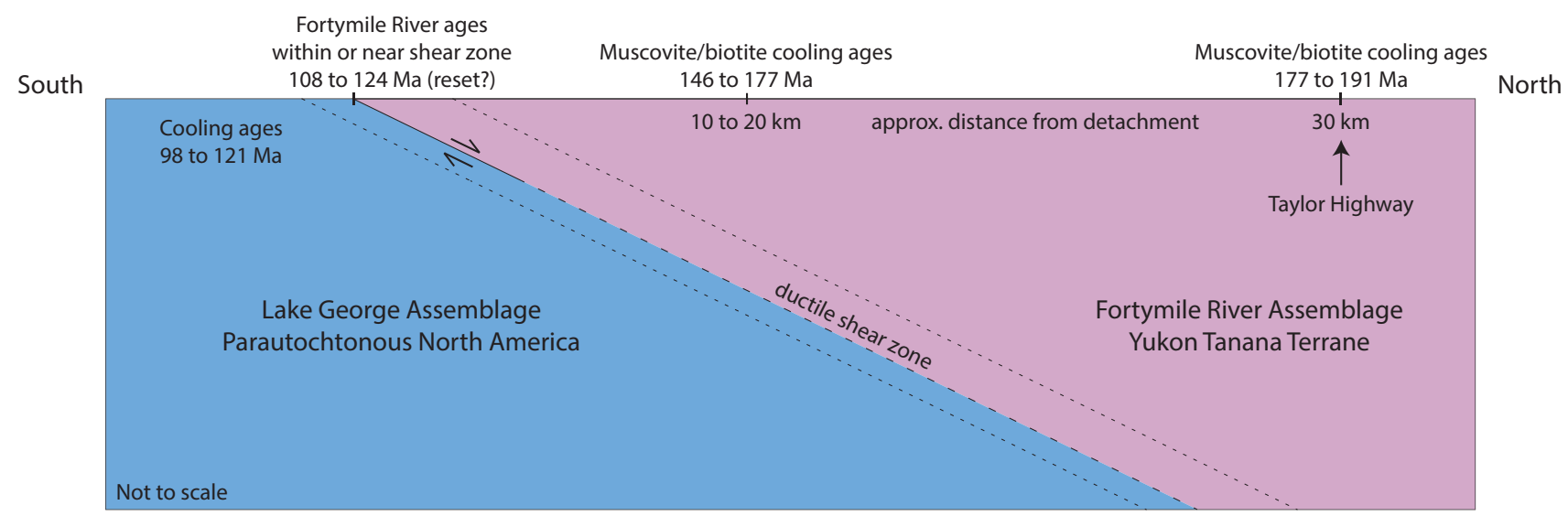

Figure 2. Schematic illustration showing cooling ages in relation to the ductile detachment separating the Fortymile River assemblage of the Yukon Tanana terrane from the Lake George assemblage of parautochthonous North America.

83AFr4087A and 83AFr4087B were collected in the Fortymile River assemblage about $40 \mathrm{~km}$ north of the detachment. The cooling ages differ by $17 \mathrm{~m} . \mathrm{y}$. (Wilson and others, 2015), indicating a cooling rate of $11.2^{\circ} \mathrm{C} / \mathrm{m}$.y. using the closure temperatures calculated above and an exhumation rate of $0.4 \mathrm{~km} / \mathrm{m}$.y. assuming a geothermal gradient of $25^{\circ} \mathrm{C} / \mathrm{km}$. Hornblende and biotite ages closer to the detachment (about $12 \mathrm{~km}$ ) from samples collected less than 2 $\mathrm{km}$ apart also vary by over $17 \mathrm{~m} . \mathrm{y}$. (16-YTT-035 and 16-YTT-036 in Jones and Benowitz, 2020) and record an exhumation rate of $0.4 \mathrm{~km} / \mathrm{m}$.y. Paired hornblende and muscovite ages from 00RF126A and 00RF126B (Flynn, 2003), also $12 \mathrm{~km}$ north of the detachment, differ by 7.3 m.y. and suggest a cooling rate of $11.6^{\circ} \mathrm{C} / \mathrm{m}$.y. and an exhumation rate of $0.5 \mathrm{~km} / \mathrm{m}$.y. between 175 and $167 \mathrm{Ma}$.

Paired biotite and hornblende cooling ages were analyzed from both samples TH-29 and TH-39 (Hansen and others, 1991). These samples were collected from the Fortymile River assemblage along the Taylor Highway more than $30 \mathrm{~km}$ from the detachment. ${ }^{40} \mathrm{Ar} r{ }^{39} \mathrm{Ar}$ cooling ages from these minerals vary by less than 2.3 m.y., and imply cooling rates of 87 to $119^{\circ} \mathrm{C} / \mathrm{m}$.y. Assuming a geothermal gradient of $25^{\circ} \mathrm{C} / \mathrm{km}$, the cooling rates suggest very high exhumation rates of 3.5 to $4.8 \mathrm{~km} / \mathrm{m}$.y. during the Late Triassic to Early Jurassic thrust event proposed by Hansen and Dusel-Bacon (1998).
The calculated exhumation rates indicate a period of tectonic uplift of $0.4-0.5 \mathrm{~km} / \mathrm{m}$.y. between 204 and $167 \mathrm{Ma}$ for a large area north of the Fortymile River-Lake George detachment. A period of more rapid $4 \mathrm{~km} / \mathrm{m}$.y. exhumation is implied for an area along the Taylor Highway at around $185 \mathrm{Ma}$. This exhumation rate is as high as periods of rapid uplift in the eastern syntaxis of the Himalaya (Bracciali and others, 2016) and much higher than other studied orogens. We therefore suggest that rapid uplift was very local or shortlived, or the ${ }^{40} \mathrm{Ar} /{ }^{39} \mathrm{Ar}$ hornblende and biotite ages from samples TH-29 and TH-39 actually record heating by a nearby unseen intrusion. Early Jurassic plutons have been mapped near the sample locations (Werdon and others, 2001). Alternatively, the apparent rapid exhumation rate could also be a result of misinterpretation of the hornblende cooling ages. We are not able to determine if the hornblende in the samples from Hansen and others (1991) contained phyllosilicate inclusions or exsolution lamellae, since $\mathrm{K} / \mathrm{Ca}$ ratios were not provided. If phyllosilicate inclusions were present, hornblende closure temperatures would be lower than expected (Baldwin and others, 1990), which would result in calculated exhumation rates being too high. Additionally, if cooling rates were greater than $25^{\circ} \mathrm{C} / \mathrm{m}$.y. the closure ages used for biotite and hornblende in this modeling would not be valid. 
Two Fortymile River assemblage samples with anomalous Cretaceous cooling ages were collected within $2 \mathrm{~km}$ of the mapped Fortymile River-Lake George detachment and it is possible that the detachment is a wide shear zone that incorporated slivers of hanging-wall Fortymile River rocks into the footwall during exhumation. If that were the case, then the Fortymile River slivers, represented by samples $18 \mathrm{MLW} 132$ and $18 \mathrm{RN} 259$, would have been rapidly uplifted and cooled along with the Lake George assemblage (fig. 2). It has also been documented that crustal-scale extensional faults advect sufficient heat in their exhuming footwalls to reset thermochronometers in the overlying hanging walls (Dunkl and others, 1998). Therefore, it is possible that Fortymile River rocks proximal to the detachment were partially reset within or adjacent to the shear zone by hot lower plate rocks. Alternatively, hydrothermal fluid flow in the shear zone from nearby magmatism (e.g. the Cretaceous granite $(\mathrm{Kg})$ south of the detachment) may have provided a heat source for partial resetting of the argon system in the adjacent hanging wall. Though the nearest mapped pluton is kilometers away, abundant aplite and pegmatite dikes with the same age and composition have been mapped throughout the area and could be responsible for local heating of surrounding rocks.

We interpret the Fortymile River-Lake George detachment as a north-dipping shear zone that separates the Fortymile River assemblage (hanging wall) from the Lake George assemblage (footwall). The detachment has been segmented by subsequent left-lateral strike-slip faults, including the Sixtymile-Pika fault zone (Wypych and others, 2021). The dip of the detachment is not well determined but is estimated to be shallow and between 15 and 30 degrees (Wypych and others, 2021). Figure 3 shows $\mathrm{K}-\mathrm{Ar}$ and ${ }^{40} \mathrm{Ar} /{ }^{39} \mathrm{Ar}$ cooling ages versus structural distance above or below the detachment, assuming a 15 degree dip to the north. Hornblende cooling ages in the Fortymile River assemblage range from 213 to $175 \mathrm{Ma}$. Hornblende ages do not vary systematically with structural distance, though hornblende ages have not been reported within 2500 meters of the detachment. The lack of a trend in hornblende ages with distance to the detachment suggests the entire Fortymile River assemblage in the study area cooled through approximately $500^{\circ} \mathrm{C}$ in the Early Jurassic. Muscovite and biotite ages from more than $6000 \mathrm{~m}$ above the detachment range from 194 to $177 \mathrm{Ma}$. As expected, mica cooling ages are younger than hornblende cooling ages, consistent with lower closure temperatures for the micas. The similar range of cooling ages suggests rapid cooling of Fortymile River assemblage from approximately $500^{\circ} \mathrm{C}$ to $300^{\circ} \mathrm{C}$ in the Early Jurassic. At structural distances less than $6,000 \mathrm{~m}$ above the detachment muscovite and biotite ages range from 177 to $146 \mathrm{Ma}$. There may be several interpretations for the younger, more heterogeneous muscovite and biotite ages within $6,000 \mathrm{~m}$ of the detachment. It is possible that the cooling from $500^{\circ} \mathrm{C}$ to $300^{\circ} \mathrm{C}$ was much slower in this part of the Fortymile River assemblage, though there is no structural data to support a difference in tectonic history between the upper and lower parts of the Fortymile River assemblage. Our preferred interpretation is that young and heterogeneous muscovite and biotite ages represent a Jurassic partial retention zone (PRZ) for micas.

An argon PRZ was defined by Baldwin and Lister (1998) as the range of depths in the crust where temperatures allow radiogenic argon to be partially retained and partially diffused from potassium-bearing minerals. The proportion of argon that is retained will vary with grain size and the residence time in the PRZ. When subsequently uplifted, the apparent age of samples from within the PRZ will be younger than the initial tectonic event and older than later tectonic events. The PRZ depths for different potassium-bearing minerals are related to their closure temperatures, with higher closure temperature correlating with deeper partial retention zones, though the zones can overlap (Baldwin and Lister, 1998). Consequently, all potassium-bearing minerals will record a tectonic event at shallow levels, but at deeper levels, the ages from lower-closure-temperature minerals will be heterogeneous and younger than 
$\mathrm{Ar} / \mathrm{Ar}$ and $\mathrm{K} / \mathrm{Ar}$ ages versus structural distance from Fortymile-Lake George Detachment

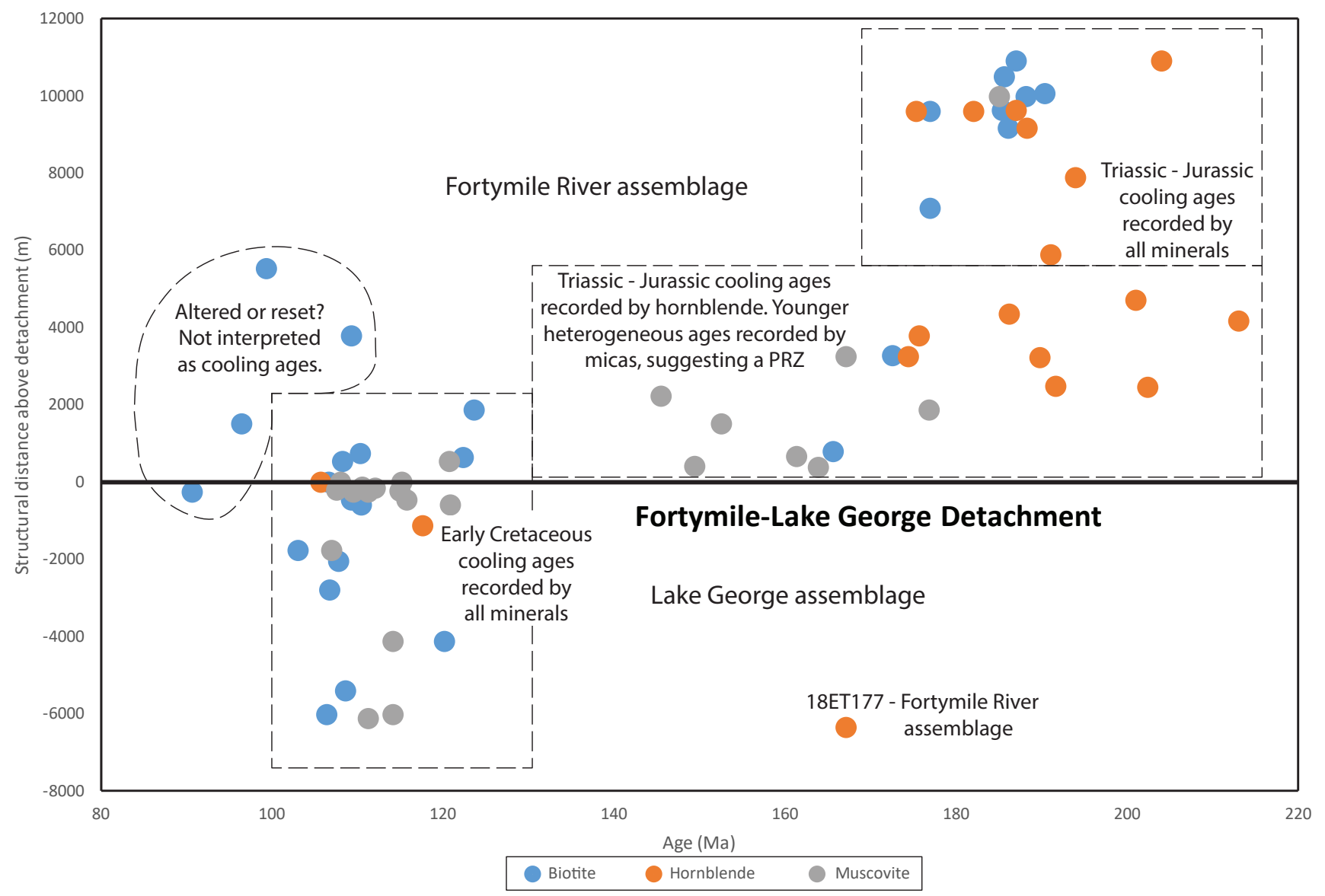

Figure 3. Plot of ${ }^{40} \mathrm{Ar} /{ }^{39} \mathrm{Ar}$ and $\mathrm{K}$-Ar cooling ages of metamorphic rocks versus structural distance from the Fortymile River-Lake George detachment, assuming a 15 degree north dip on the detachment. Cooling ages of all potassium-bearing minerals from higher structural levels in the Fortymile River assemblage record Late Triassic-Jurassic exhumation. Heterogeneous cooling ages at lower structural levels in the Fortymile River assemblage suggest a fossil partial retention zone is exposed at the surface. Cooling ages in the Lake George assemblage and within the shear zone record Early Cretaceous exhumation due to extension on the detachment.

the tectonic event. The cooling ages in the Fortymile River assemblage from hornblende, muscovite, and biotite record Late Triassic-Jurassic uplift at structural distances more than 6,000 $\mathrm{m}$ above from the detachment (fig. 3). Hornblende records similar cooling ages within $6,000 \mathrm{~m}$ of the detachment, but mica cooling ages are younger and heterogeneous, suggesting Late Triassic-Jurassic PRZs for both biotite and muscovite (fig. 3). The cooling ages record broad uplift of the Fortymile River assemblage across the northeast Tanacross and southeast Eagle quadrangles and imply subsequent northward tilting of the Fortymile River assemblage to expose the fossil biotite PRZ and muscovite PRZ north of the Fortymile River-Lake
George detachment (fig. 4). Cooling ages range from mid-Jurassic to mid-Cretaceous at the structural level of the proposed fossil muscovite and biotite PRZs (fig. 3), with most of the ages between 176 and $146 \mathrm{Ma}$. The youngest cooling ages in this layer are mid-Cretaceous, which suggests that this structural level of the Fortymile River assemblage cooled below the temperatures of partial argon retention during or after the mid-Cretaceous.

\section{Lake George Assemblage}

The Lake George assemblage in the study area is dominated by Mississippian potassium feldspar augen-bearing Divide Mountain orthogneiss 
Before extension on the

Fortymile River-Lake George detachment

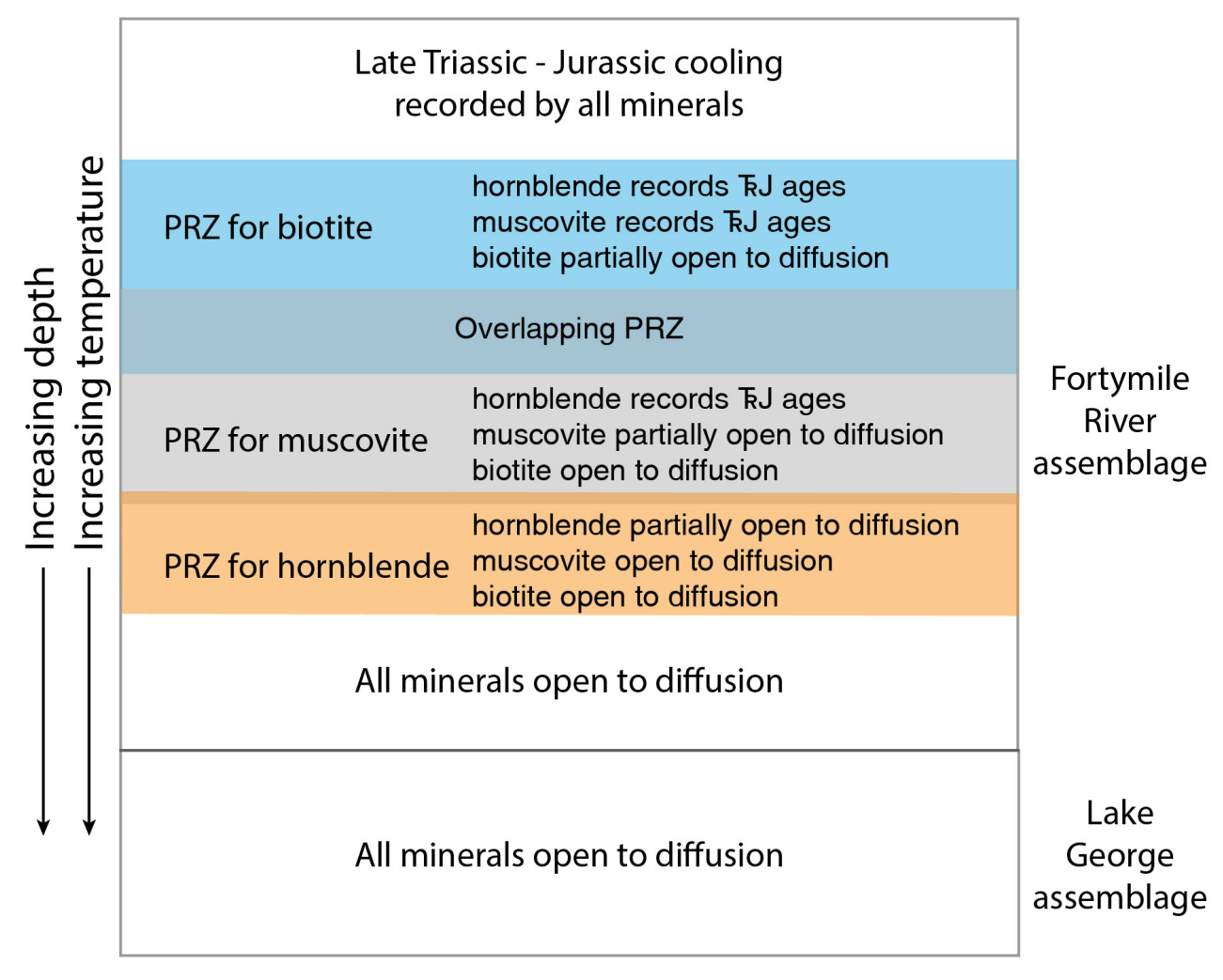

B

After extension on the

Fortymile River-Lake George detachment

Late Triassic - Jurassic cooling recorded by all minerals

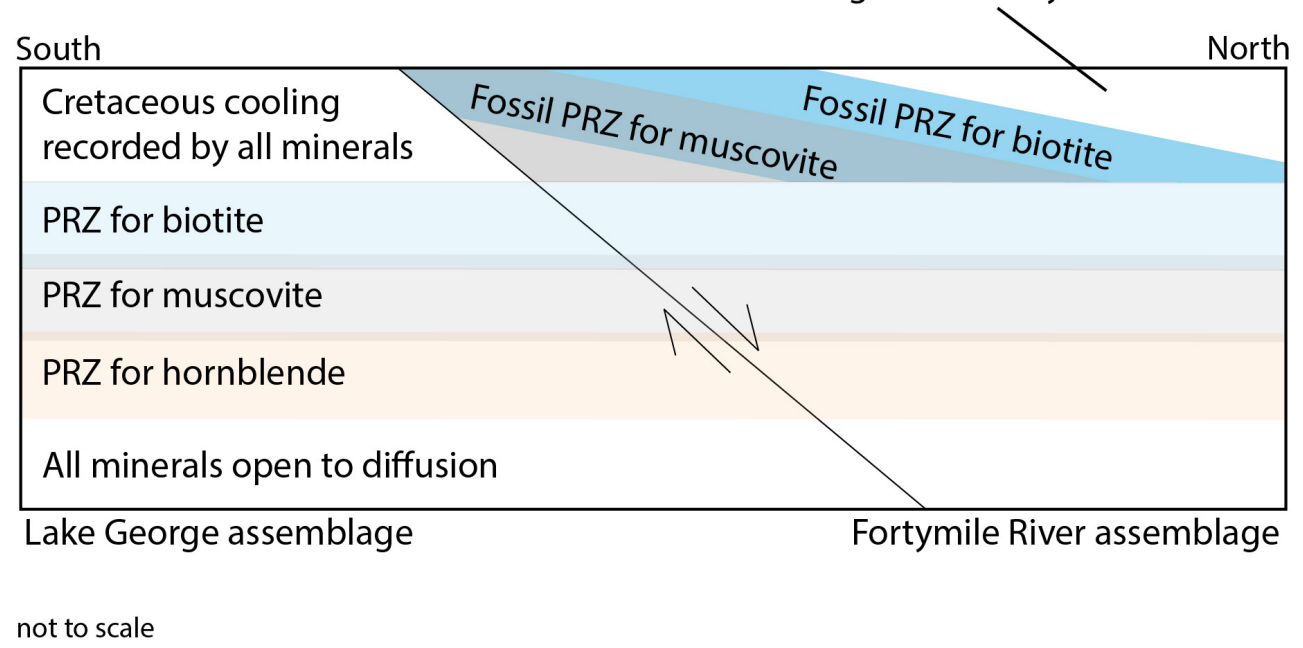

Figure 4. Schematic cross-section showing ${ }^{40} \mathrm{Ar} /{ }^{39} \mathrm{Ar}$ and $\mathrm{K}-\mathrm{Ar}$ cooling ages and partial retention zones (PRZ) in the study area. A. Expected cooling ages in the Fortymile River assemblage after Late Triassic-Jurassic thrust faulting and before Cretaceous extension on the Fortymile River-Lake George detachment. B. Cooling ages in both assemblages after Cretaceous extension on the detachment, showing both present (since the post-Cretaceous) PRZs and fossil Triassic-Jurassic PRZs. 
(Wypych and others, 2021). The Cretaceous cooling ages across the map area confirm that the Divide Mountain orthogneiss underwent similar uplift and cooling wherever it is exposed. Therefore, the location of the shallowly north-dipping Fortymile River-Lake George detachment can confidently be mapped north of the northern-most observation of Divide Mountain orthogneiss and north of similar Early Cretaceous cooling ages within other Lake George assemblage units.

Cooling rates between 10.1 and $16.3^{\circ} \mathrm{C} / \mathrm{m}$.y. were calculated from three paired muscovite/biotite samples from Naibert and others (2020). Assuming a geothermal gradient of $25^{\circ} \mathrm{C} / \mathrm{km}$, these cooling rates suggest extensional exhumation between 0.4 and $0.7 \mathrm{~mm} /$ year between 121 and $106 \mathrm{Ma}$ along the nearby detachment. Slightly higher exhumation rates of 1.1 and $1.4 \mathrm{~mm} /$ year were calculated for samples 74ASj104T (Wilson and others, 2015) and 90ADb2E (Dusel-Bacon and others, 2002) with paired muscovite and biotite ages. These samples are all within $7 \mathrm{~km}$ of the Fortymile River-Lake George detachment. A cooling rate of $13.6^{\circ} \mathrm{C} / \mathrm{m}$.y. and an exhumation rate of $0.5 \mathrm{~mm} /$ year were calculated for sample 18KS131 from $20 \mathrm{~km}$ south of the detachment. The calculated exhumation rate is similar to the rates closer to the detachment. These data support a model of broad uniform uplift and cooling in the Lake George assemblage across the northeast Tanacross Quadrangle between 121 and $98 \mathrm{Ma}$ (fig. 2).

\section{CONCLUSIONS}

Our preferred interpretation of exposed structural levels after Triassic-Early Jurassic thrust faulting and Cretaceous extension is shown in figure 4. The Fortymile River assemblage was uplifted during Triassic-Early Jurassic thrust faulting and the northern part of the Fortymile River assemblage around the Taylor Highway was exhumed through the argon closure temperatures of all the potassium-bearing minerals at that time (fig. 4A). The southern part of the Fortymile River assemblage was exhumed through the closure temperature of hornblende during thrust faulting but likely remained at temperatures high enough to allow partial argon diffusion from muscovite and biotite. Exhumation in the Fortymile River assemblage during thrusting was around $0.4-0.5 \mathrm{~mm} /$ year. Higher exhumation rates may have occurred locally or over short time periods. Muscovite and biotite partial retention zones were then exhumed during mid-Cretaceous extension on the Fortymile RiverLake George detachment by northward tilting in the hanging wall of the detachment followed by erosional unroofing (fig. 4B). Lake George assemblage rocks in the footwall were exhumed through the argon closure temperature of all three minerals during the mid-Cretaceous (Fig. 4B). Consistent Cretaceous cooling ages and exhumation rates of 0.4 to $1.4 \mathrm{~mm} /$ year across the Lake George assemblage suggest broad-scale uplift without major tilting or internal deformation in the footwall of the detachment. One $167 \mathrm{Ma}$ hornblende ${ }^{40} \mathrm{Ar} /{ }^{39} \mathrm{Ar}$ cooling age from the southeast corner of the study area is presumably Fortymile River assemblage or another allochthonous unit, indicating that the Fortymile River-Lake George detachment may be folded and exposed to the south of the study area. Further geochronology and future mapping is needed to identify allochthonous units in the eastern Tanacross Quadrangle.

Future ${ }^{40} \mathrm{Ar} /{ }^{39} \mathrm{Ar}$ studies would benefit from dating multiple potassium-bearing minerals at the same location or at nearby locations so that cooling and exhumation rates can be calculated, and so fossil partial retention zones can be identified or verified.

\section{ACKNOWLEDGMENTS}

The DGGS Northeast Tanacross project was funded by State of Alaska general funds and by the USGS National Cooperative Geologic Mapping Program under STATEMAP award number G18AC00137 for 2018. The authors acknowledge Bob Gillis and Sean Regan for helpful manuscript reviews, and the 2017 and 2018 Northeast Tanacross project field crew: Karri R. Sicard, Melanie B. Werdon, Jen E. Athey, Amanda L. Willingham, Alec C. Lockett, Rainer J. Newberry, and W. Chris Wyatt. 


\section{REFERENCES}

Baldwin, S.L., Harrison, T.M., and Fitz Gerald, J.D., 1990, Diffusion in metamorphic hornblende: Contributions to Mineralogy and Petrology, v. 105, p. 691-703.

Baldwin, S.L., and Lister, G.S., 1998, Thermochronology of the South Cyclades shear zone, Ios, Greece: Effects of ductile shear in the argon partial retention zone: Journal of Geophysical Research, v. 103, p. 7,315-7,336.

Bracciali, Laura, Parrish, R.R., Najman, Yani, Smye, Andrew, Carter, Andrew, Wijbrans, J.R., 2016, Plio-Pleistocene exhumation of the eastern Himalayan syntaxis and its domal 'popup': Earth-Science Reviews, v. 160, p. 350-385.

Brandon, M.T., Roden-Tice, M.K., and Garver, J.I., 1998, Late Cenozoic exhumation of the Cascadia accretionary wedge in the Olympic Mountains, northwest Washington State: Geological Society of America Bulletin, v. 110, p. 985-1009.

Dunkl, Istvan, Grasemann, Bernhard, and Frisch, Wolfgang, 1998, Thermal effects of a metamorphic core complex on hanging wall synrift sediments: an example from the Rechnitz Window, Eastern Alps: Tectonophysics, v. 297, p. 31-50.

Dusel-Bacon, Cynthia, Lanphere, M.A., Sharp, W.D., Layer, P.W., and Hanson, V.L., 2002, Mesozoic thermal history and timing of structural events for the Yukon-Tanana Upland, east-central Alaska- ${ }^{40} \mathrm{Ar} /{ }^{39} \mathrm{Ar}$ data from metamorphic and plutonic rocks: Canadian Journal of Earth Sciences, v. 39, p. 1,013-1,051.

Dusel-Bacon, Cynthia., Hopkins, M.J., Mortensen, J.K., Dashevsky, S.S., Bressler, J.R., and Day, W.C., 2006, Paleozoic tectonic and metallogenic evolution of the pericratonic rocks of eastcentral Alaska and adjacent Yukon, in Colpron, Maurice, and Nelson, J.L. eds., Paleozoic Evolution and Metallogeny of Pericratonic Terranes at the Ancient Pacific Margin of North America, Canadian and Alaskan Cordillera: Geological Association of Canada, Special Paper 45 , p. 25-74.

Flynn, R.L., 2003, Geology of the Boundary area,
Eagle A-1 and Tanacross D-1 quadrangles, eastcentral Alaska: Fairbanks, Alaska, University of Alaska Fairbanks, M.S. thesis, 185 p.

Grove, Marty, Harrison, T.M., 1996, 40Ar* diffusion in Fe-rich biotite: American Mineralogist, v. 81, p. 940-951.

Hansen, V.L., Heizler, M.T., and Harrison, T.M., 1991, Mesozoic thermal evolution of the YukonTanana composite terrane; new evidence from ${ }^{40} \mathrm{Ar} /{ }^{39} \mathrm{Ar}$ data: Tectonics, v. 10 , no. 1 , p. $51-76$. Hansen, V.L., and Dusel-Bacon, Cynthia., 1998, Structural and kinematic evolution of the Yukon-Tanana upland tectonites, east-central Alaska: A record of late Paleozoic to Mesozoic crustal assembly: Geological Society of America Bulletin, v. 110; no. 2, p. 211-230.

Harrison, T.M., 1981, Diffusion of $40 \mathrm{Ar}$ in hornblende: Contributions to Mineralogy and Petrology, v. 78, p. 324-331.

Harrison, T.M., Celerier, Julien, Aikman, A.B., Hermann, Joerg, Heizler, M.T., 2009, Diffusion of ${ }_{40} \mathrm{Ar}$ in muscovite: Geochimica et Cosmochimica Acta, v. 73, p. 1039-1051.

Jones, J.V., Todd, Erin, Caine, J.S., HolmDenoma, C.S., Ryan, J.J., and Benowitz, J.A., 2017, Late Permian (ca. 267-257 Ma) magmatism, deformation, and metamorphism and lithotectonic associations of the Ladue River unit in east-central Alaska: Geological Society of America Annual Meeting, October 22-25, Seattle, Washington.

Jones, J.V., and Benowitz, J.A., 2020, ${ }^{40} \mathrm{Ar} /{ }^{39} \mathrm{Ar}$ isotopic data and ages for rocks from the Yukon-Tanana upland of eastern Alaska and the northern Aleutian Range of south-central Alaska: U.S. Geological Survey data release. doi. org/10.5066/P96762V3

Naibert, T.J., Benowitz, J.A., Wypych, Alicja, Sicard, K.R., and Twelker, Evan, 2020, ${ }^{40} \mathrm{Ar} /{ }^{39} \mathrm{Ar}$ data from the Tanacross D-1 and parts of the D-2, C-1, and C-2 quadrangles, Alaska: Alaska Division of Geological \& Geophysical Surveys Raw Data File 2020-12, 35 p. doi. org/10.14509/30466

Warren, C.J., Hanke, Felix, and Kelley, S.P., 2012, When can muscovite ${ }^{40} \mathrm{Ar} /{ }^{39} \mathrm{Ar}$ dating constrain 
the timing of metamorphic exhumation?: Chemical Geology, v. 291, p. 79-86.

Werdon, M.B., Newberry, R.J., Szumigala, D.J., and Pinney, D.S., 2001, Geologic map of the Eagle A-2 Quadrangle, Fortymile mining district, Alaska: Alaska Division of Geological \& Geophysical Surveys Preliminary Interpretive Report 2001-3A, 1 sheet, scale 1:63,360, v. 1.0.1. doi.org/10.14509/2669

Wilson, F.H., Hults, C.P., Mull, C.G., and Karl, S.M., 2015, Geologic map of Alaska: U.S. Geological Survey Scientific Investigations Map 3340, 197 p., 2 sheets, scale 1:1,584,000.

Wypych, Alicja, Hubbard, T.D., Naibert, T.J., Athey, J.E., Newberry, R.J., Sicard, K.R., Twelker, Evan, Werdon, M.B., Willingham, A.L., Wyatt, W.C., and Lockett, A.C., 2019, Northeastern Tanacross geologic map, Tanacross D-1, D-2, $\mathrm{C}-1$, and C-2 quadrangles, Alaska: Alaska Division of Geological \& Geophysical Surveys Preliminary Interpretive Report 2019-6, 20 p., 1 sheet, scale 1:63,360. doi.org/10.14509/30197 2021, Chapter B: Northeast Tanacross geologic map and map units and descriptions, in Wypych, Alicja, Northeast Tanacross geologic mapping project, Alaska: Alaska Division of Geological \& Geophysical Surveys Report of Investigation 2020-9B. doi.org/10.14509/30539 Wypych, Alicja, Twelker, Evan, Athey, J.E., Lockett, A.C., Naibert, T.J., Sicard, K.R., Werdon, M.B., and Willingham, A.L., 2017, Major-oxide and trace-element geochemical data from rocks collected in the Tanacross C-1, D-1, and D-2 quadrangles, Alaska in 2017: Alaska Division of Geological \& Geophysical Surveys Raw Data File 2017-10, 4 p. doi.org/10.14509/29778

Wypych, Alicja, Naibert, T.J., Athey, J.E., Newberry, R.J., Sicard, K.R., Twelker, Evan, Werdon, M.B., Willingham, A.L., and Wyatt, W.C., 2018, Major-oxide and trace-element geochemical data from rocks collected in 2018 for the Northeast Tanacross project, Tanacross C-1, C-2, D-1, and D-2 quadrangles, Alaska: Alaska Division of Geological \& Geophysical Surveys Raw Data File 2018-4, 4 p. doi. org/10.14509/30113 


\section{CHAPTER D: STRUCTURAL GEOLOGY OBSERVATIONS IN NORTHEAST TANACROSS}

Travis J. Naibert ${ }^{1}$

\section{INTRODUCTION}

Structure orientations were measured at 951 stations in the northeast Tanacross map area, including measurements of joint planes, minor faults, dikes, foliation and schistosity planes, mineral and crenulation lineations, and fold axes. Shear sense indicators were only noted at a few locations on fault and fracture surfaces and within deformation fabrics. Faults and unit contacts were identified using lithology, magnetic susceptibility, geochemistry, and metamorphic grade at field stations, as well as interpreted from topography, satellite imagery, and published geophysical surveys (Burns and others, 2011; Emond and others, 2015).

Two metamorphic assemblages underlie most of the northeast Tanacross map area. The Fortymile River assemblage consists of amphibolite facies schist, quartzite, and paragneiss, with minor marble, intermediate to felsic metavolcanic orthogneiss, and amphibolite. The Fortymile River assemblage was previously described by DuselBacon and others (2002) and interpreted as part of the allochthonous Yukon-Tanana terrane. The Fortymile River assemblage is intruded by the Late Triassic Taylor Mountain Batholith and several smaller Late Triassic to Early Jurassic plutons (Hansen and Dusel-Bacon, 1998; Werdon and others, 2001; Dusel-Bacon and others, 2002). The amphibolite facies Lake George assemblage is dominated by Mississippian-Devonian potassium-feldspar augen orthogneiss. Paragneiss, quartzite, quartz-mica schist, and granitic orthogneiss (without augen) also appear in the Lake George assemblage as host rocks for the augen gneiss. The Lake George assemblage is interpreted as part of parautochthonous North America (Dusel-Bacon and others, 2002). The Fortymile River assemblage was thrust over the Lake George assemblage during collision of the Yukon-Tanana terrane with North America after the Early Jurassic, and the Lake George assemblage was later exhumed during regional extension (Dusel-Bacon and others, 2002). Both the Lake George and Fortymile River assemblages are intruded by similar Early Cretaceous (100-110 Ma) granite plutons, and aplitic or pegmatitic dikes, which suggests that the two units were juxtaposed at a similar structural level by that time (Naibert and others, 2018).

\section{FOLIATION MEASUREMENTS AND FOLDING}

Metamorphic units in the Fortymile River and Lake George assemblages are moderately to strongly foliated, and foliations are dominantly subhorizontal to moderately dipping. Lithologic contacts are parallel to foliation at most outcrops with multiple lithologies, but limited exposure makes it unclear if this relationship is true throughout the field area. Field observations of sub-meter-scale recumbent isoclinal folds of an early generation of foliation are parallel or subparallel to the dominant foliation, which suggests that the dominant foliation is an axial-planar fabric formed after the early generation of folding, or that the early generation of foliation has been transposed by isoclinal folding into the dominant foliation (fig. 1). Outcrop-scale isoclinal recumbent folding was observed mostly in metasedimentary units, and related folding in metaplutonic rocks is likely present at different scales due to different unit thicknesses.

Observed foliations were often broadly consistent between adjacent ridgelines but varied considerably across the field area. Foliations in the Fortymile River assemblage do not have a domi-

${ }^{1}$ Alaska Division of Geological \& Geophysical Surveys, 3354 College Rd., Fairbanks, Alaska 99709-3707. 

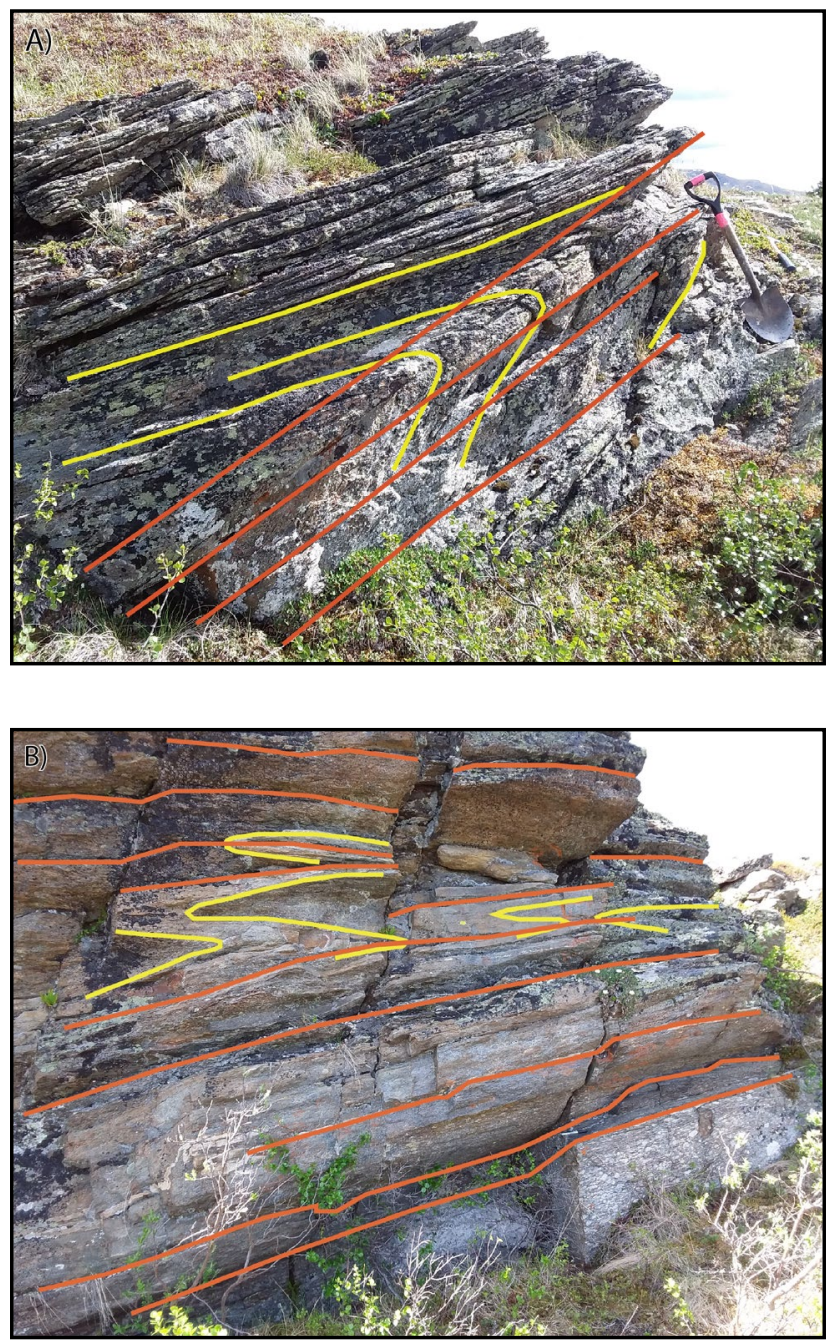

Figure 1. Outcrop photos at (A) station 18MBW034 just above the detachment in the Fortymile River assemblage and (B) station 18AW070 in the Lake George assemblage. An early foliation (yellow) was observed in some metasedimentary units and is isoclinally folded. A later foliation (red) formed parallel to the axial planes of these folds and is the dominant foliation in the Lake George assemblage.

nant orientation-except that dips steeper than 50 degrees are uncommon (fig. 2A). Foliations in the Lake George assemblage also vary widely, but poles to foliation plot in a wide girdle pattern on a stereonet (fig. 2B), suggesting that Lake George assemblage foliations are folded around a common subhorizontal WNW-ESE axis. This interpretation matches the orientation of outcrop-scale fold axes measured in the Lake George assemblage, which are dominantly NW-SE and gently dipping, irrespective of axial plane orientation (fig. 2C). Outcrop-scale fold axis measurements from the Fortymile River assemblage are similar to those in the Lake George assemblage, despite no dominant foliation pattern at the map scale in the Fortymile River assemblage.

Meter-scale to outcrop-scale folding was observed in both the Fortymile and the Lake George assemblages and ranged from open upright folding to recumbent isoclinal folds. A consistent fold vergence direction was not observed in the field area. Hansen and Dusel-Bacon (1998) previously described open to gentle upright folding with east-west axial traces in both metamorphic assemblages. While map-scale folding is indicated by foliation measurements in a few locations, lack of exposure makes it unclear how extensive largescale folding is. Identification of large-scale folding is also complicated by later motion on high-angle brittle faults that cut the ductile fabrics (see below).

Comparable meso-scale folding in both the Fortymile River and Lake George assemblages suggests that folding occurred during or after the assemblages were juxtaposed by Triassic to Jurassic thrusting of allochthonous assemblages over continental North America (Hansen and Dusel-Bacon, 1998). Alternatively, folding in the Fortymile and Lake George assemblages could have occurred during ductile extension along a north-dipping detachment (discussed below), which exhumed the parautochthonous Lake George assemblage in the mid-Cretaceous (Hansen and Dusel-Bacon, 1998).

\section{LINEATION MEASUREMENTS AND LOW-ANGLE DETACHMENT}

The contact between the Fortymile River assemblage and the Lake George assemblage is poorly exposed across the map area south of Liberty Creek and the Sixtymile River. We concur with the interpretation of Hansen and Dusel-Bacon (1998) that the boundary is a shallowly to moderately north-dipping extensional detachment surface (Fortymile-Lake George Detachment; fig. 3, red lines). Late Jurassic to Early Cretaceous ${ }^{40} \mathrm{Ar} /{ }^{39} \mathrm{Ar}$ metamorphic cooling ages have been reported for Fortymile River assemblage rocks north of the 


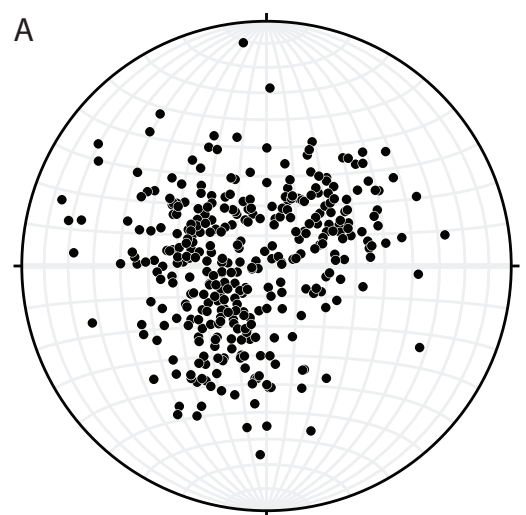

$\mathrm{N}=362$
B

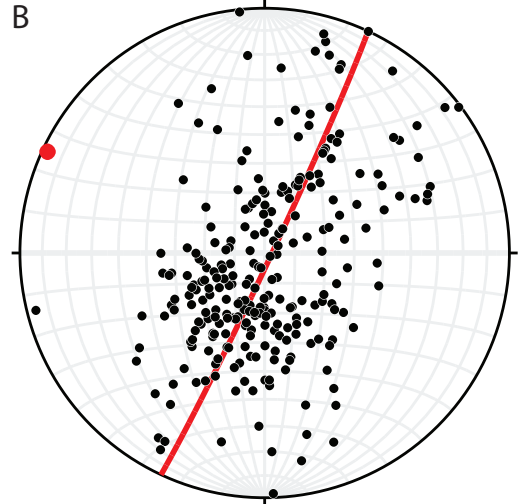

$\mathrm{N}=264$

Best-fit fold axis trend/plunge: 295/2.3

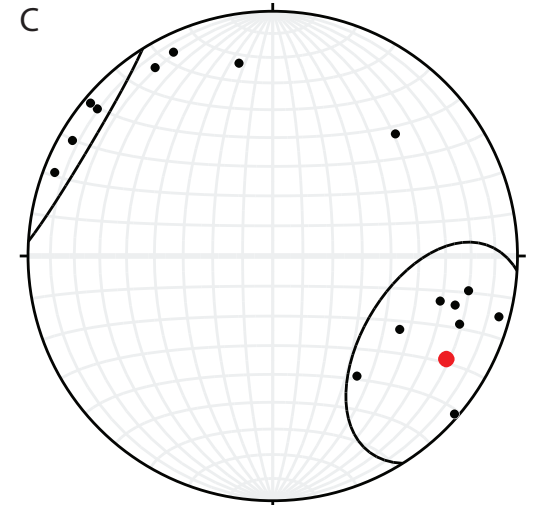

$N=16$

Best-fit fold axis trend/plunge:

$120.7 / 18.8 \pm 32.7$

Figure 2. Lower hemisphere, equal-area stereonet plots of $(\mathbf{A})$ poles to foliation planes in the Fortymile assemblage; (B) poles to foliation planes in the Lake George assemblage including a cylindrical best fit plane and axis (in red); (C) trend and plunge of measured fold axes in the northeast Tanacross field area in Fortymile River and Lake George assemblage metamorphic rocks, including a conical best fit axis (in red).

detachment, and Mid-Cretaceous ${ }^{40} \mathrm{Ar} /{ }^{39} \mathrm{Ar}$ metamorphic cooling ages have been reported for Lake George assemblage rocks south of the detachment (fig. 4; Hansen and Dusel-Bacon, 1998; Jones and others, 2017; Naibert and others, 2020), indicating that crustal extension along the proposed detachment and exhumation of footwall rocks likely occurred during the mid-Cretaceous. The Fortymile River and Lake George assemblages both include significant quartzite, schist, and paragneiss layers, as well as interlayered orthogneiss, and it can be difficult to differentiate the assemblage in the field at the outcrop scale. Where metamorphic cooling ages are available, the detachment has been mapped between stations with mid-Cretaceous $(-100-120$ $\mathrm{Ma}$ ) and Jurassic/Early Cretaceous metamorphic cooling ages. Between ${ }^{40} \mathrm{Ar} /{ }^{39} \mathrm{Ar}$ age locations, the detachment has been mapped north of the northernmost observations of Divide Mountain augen orthogneiss ( $-355 \mathrm{Ma}$; Naibert and others, 2021; MDag in Wypych and others, 2021), a definitive unit in the Lake George assemblage in this part of the map area. The detachment is likely an approximately kilometer-wide fault zone in map view (structural thickness of at least $350 \mathrm{~m}$ ) that extends north into the lower Fortymile River assemblage.
Evidence for a broad shear zone includes multiple abrupt changes in foliation- orientation over short distances, increased shear of porphyroclasts and decreasing porphyroclast grain size in orthogneiss within the shear zone, and a pronounced band of conductivity in published electromagnetic surveys (Burns and others, 2011).

Mineral and stretching lineations in both the Fortymile River and Lake George assemblages are dominantly subhorizontal and trend NW-SE (fig. 5A). The exception is a population of mineral lineations in the Fortymile River assemblage between Liberty and Dewey Creeks, which are subhorizontal and trend NE-SW (fig. 5B, shown in green; fig. 3 , circled in white). If mineral lineations are interpreted as a reflection of ductile shear sense, then these data are in general agreement with Hansen and Dusel-Bacon (1998), who reported northeast-directed shear sense indicators in the Fortymile River assemblage and northwest- and southeast-directed shear sense indicators in the Lake George assemblage and across the detachment in the lower Fortymile River assemblage. Hansen and Dusel-Bacon (1998) interpreted the northeast-directed shear to be due to Triassic subduction-related compression in the Fortymile River assemblage. Subduction was 


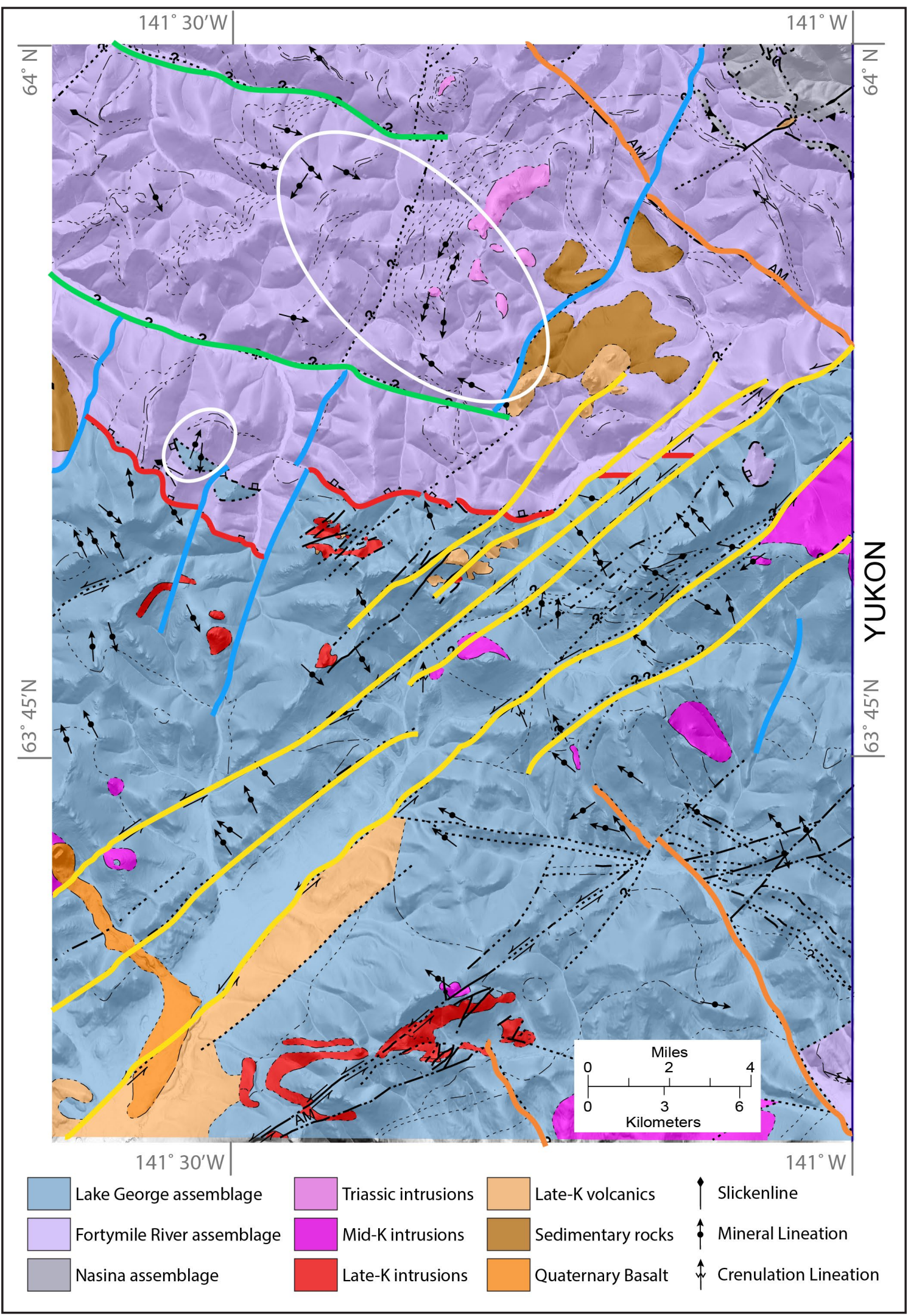

Figure 3. Map of the northeast Tanacross area showing major structures: Fortymile-Lake George Detachment (red); Sixtymile-Pika fault zone (yellow); NE-SW high-angle fault set (blue); WNW-ESE Liberty Creek and Dewey Creek faults (green); and NW-SE high-angle faults (orange). Areas circled in white are a population of NE-SW-trending lineations depicted in figure 5B. Map unit colors are as indicated on the northeast Tanacross Geologic Map (Wypych and others, 2021). 


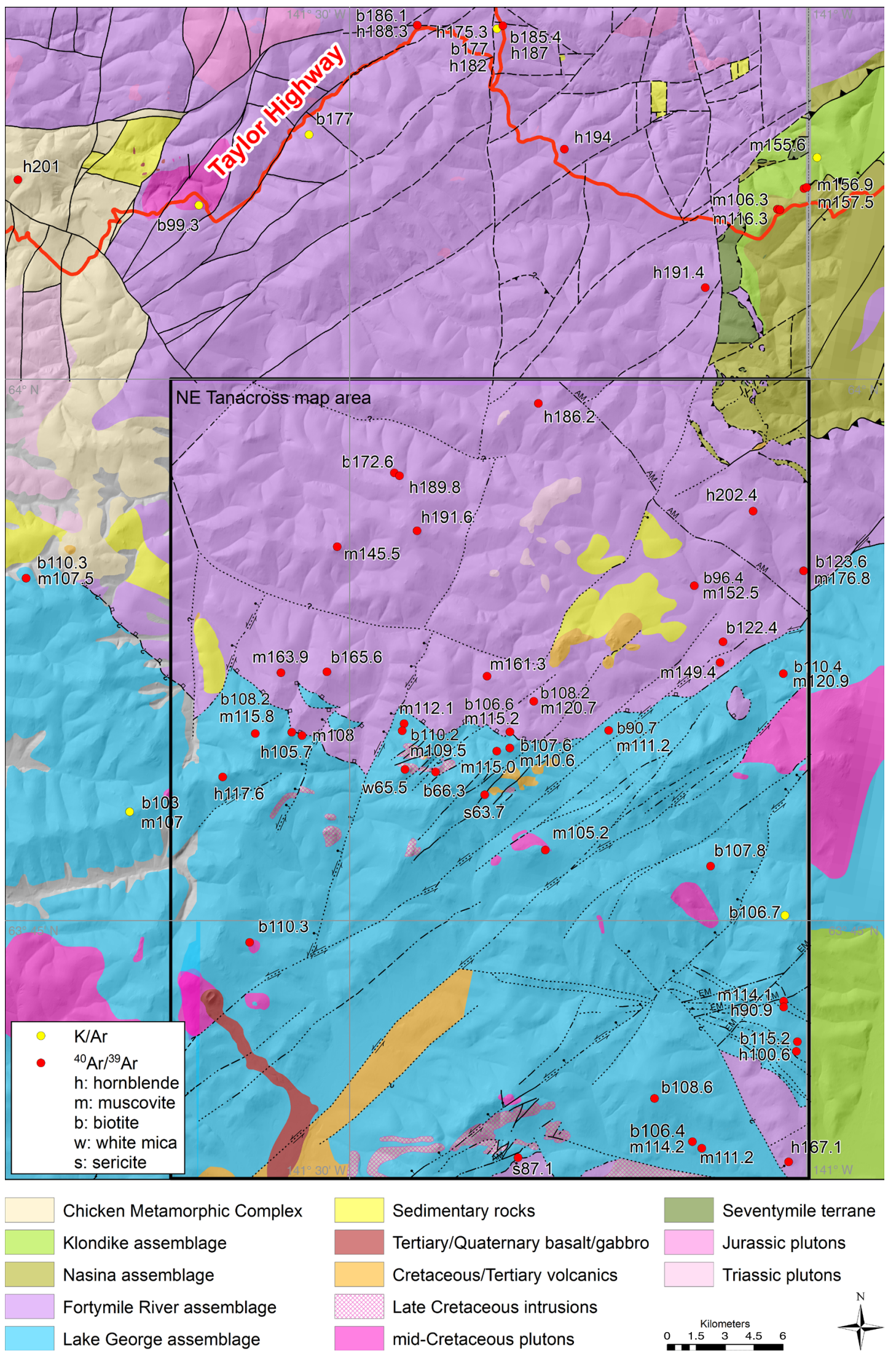

Figure 4. Map of the northeast Tanacross map area and the surrounding area showing ${ }^{40} \mathrm{Ar} /{ }^{39} \mathrm{Ar}$ cooling ages in the Fortymile and Lake George assemblages near the interpreted low-angle detachment. Ages as reported in Dusel-Bacon and others, 2002; Jones and others, 2017, Wilson and others, 2015, and Naibert and others, 2018, 2020. 


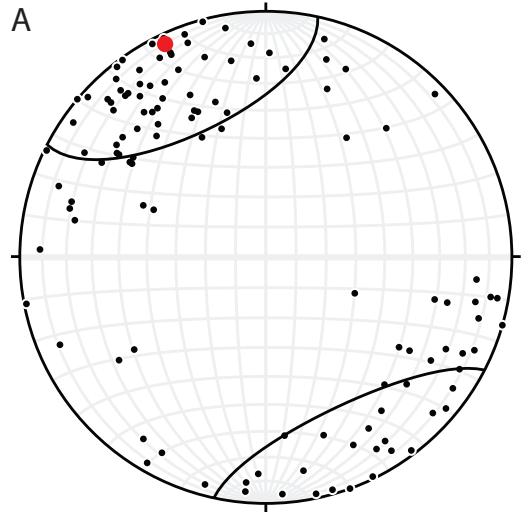

$\mathrm{N}=120$

Best-fit mineral/stretching lineation trend/plunge: 334.7/04.6 \pm 37.7

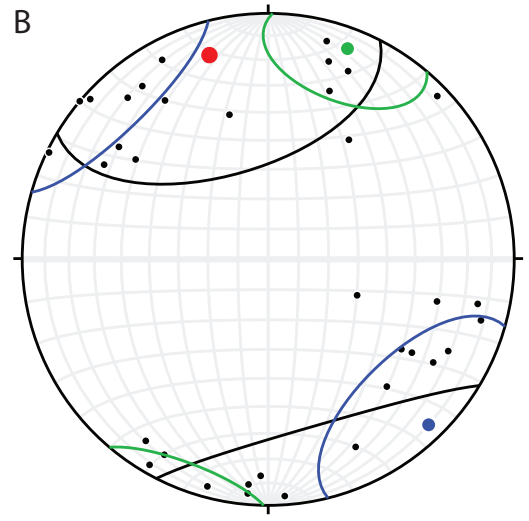

$\mathrm{N}=36$

Best-fit mineral/stretching lineation trend/plunge: 344.0/14.7 \pm 45.1

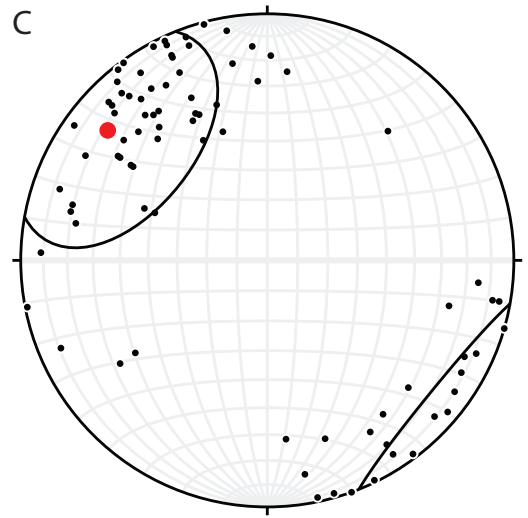

$\mathrm{N}=84$

Best-fit mineral/stretching lineation trend/plunge: 309.2/17.7 \pm 33.6

Figure 5. Lower hemisphere, equal-area stereonet plots of $(\mathbf{A})$ mineral lineations and stretching lineations in the NE Tanacross field area with NW-SE subhorizontal mean direction. B. Mineral lineations and stretching lineations in the Fortymile River assemblage including overall mean direction (red) and the mean directions of two sub-populations (NE-SW population mostly between Liberty and Dewey Creeks in green and NW-SE population in blue). C. Mineral lineations and stretching lineations in the Lake George assemblage with NW-SE subhorizontal mean direction.

followed by northwest-directed Jurassic thrusting of the Fortymile River assemblage over the parautochthonous Lake George assemblage. Subsequent southeast-directed mid-Cretaceous extension caused exhumation of the Lake George assemblage. Measured NE-SW stretching lineations between Liberty Creek and Dewey Creek (fig. 5B, in green) may record the earlier northeast-directed compression in the Fortymile River assemblage. The dominant NW-SE orientation of stretching lineations in the Fortymile River assemblage (fig. 5B, in blue), including observations multiple kilometers north of the mapped detachment surface, suggest that evidence of northeast-directed compression was overprinted by subsequent northwest-directed compression or southeast-directed extension throughout much of the Fortymile assemblage in the field area. These observations indicate that NW-SE ductile shear is widespread at lower structural levels within the allochthonous units, as described by Hansen and Dusel-Bacon (1998). Our field data included limited observations of shear sense and it is unclear if the dominant NW-SE lineations recorded across the field area were formed during northwest- or southeast-directed shear, or a combination of both.

\section{HIGH-ANGLE FAULTING}

Few direct fault measurements were possible in the map area due to poor exposure. Minor fault planes measured in the field area did not have a dominant orientation, possibly due to multiple fault generations or to rotation of structural blocks on unmeasured faults. Multiple orientations of high-angle faults cut the map area and were interpreted using field relations, aeromagnetic and electromagnetic surveys (Burns and others, 2011; Emond and others, 2015), and linear stream valleys or aligned topographic saddles along ridges. Interpreted faults were broadly similar to faults identified by Sánchez and others (2014) using a multi-dataset stacking methodology.

The most prominent fault system in the field area is the Sixtymile-Pika fault zone (striking 45-50 degrees) that extends from the Yukon border to the East Fork of the Denison Fork River and offsets the Fortymile-Lake George boundary detachment (fig. 3, yellow lines). The fault zone includes numerous parallel fault strands. We interpret this fault zone to be dominantly left-lateral strike-slip, though a smallscale fault with similar orientation was observed 
near Divide Mountain with apparent left-lateral-normal oblique slip. We have mapped a series of parallel left-lateral faults throughout the central and southern parts of the map area (Wypych and others, 2021). We mapped similar Cretaceous granites (Kg in Wypych and others, 2021) on both sides of the Sixtymile-Pika fault near the Yukon Border and just west of Prindle volcano. If these granites are part of the same intrusion, then approximately $33 \mathrm{~km}$ of left lateral slip has occurred on the Sixtymile-Pika fault system since the mid-Cretaceous. Quaternary basanite flows erupted from Prindle Volcano are likely structurally controlled by the Sixtymile-Pika fault zone and contain ultramafic xenoliths, which resemble mantle material. These observations suggest that the Sixtymile-Pika fault system is a deep feature that extends through the crust.

A second set of sinistral, strike-slip faults exist in the map area and have strikes from 15 to 30 degrees (fig 3, blue lines). The most prominent of these faults cuts through three saddles just to the east of Dude Creek north of the Fortymile-Lake George boundary detachment. It is unclear if these faults offset, are offset by, or are mutually offsetting the main NE-SW oriented faults. These faults could have formed as $\mathrm{R}$ shears to the main Sixtymile-Pika fault set.

Two parallel NW-SE faults (290-300 degree strike) were interpreted within the Fortymile assemblage in the valleys of Liberty and Dewey creeks based on parallel linear valleys (fig. 3, green lines). These faults appear to offset the NE-SW striking faults, but age relationships are difficult to determine due to poor exposure. A fourth set of high-angle faults and aeromagnetic lineations with 300-330degree strikes are offset by NE-SW striking faults (fig. 3, orange lines). This set of faults could be R' shear to the main Sixtymile-Pika fault set, but it is unclear if these faults are strike-slip or dip-slip from map relations.

Poorly consolidated conglomerates and sandstones (Kc in Wypych and others, 2021) in the northern half of the map area suggest local sedimentary depocenters or preservation of more extensive sedimentary units near some of the mapped faults, possibly due to normal or obliquenormal motion during mid-Cretaceous extension and exhumation of the Lake George assemblage or continuing extension since the Cretaceous. Similar sedimentary rocks in the Mount Fairplay area have moderately to steeply dipping beds (Foster, 1967) indicating post-deposition tilting, possibly due to local faulting. Bedding measurements in sedimentary rocks were not possible in the northeast Tanacross map area due to poor exposure; similar sedimentary rocks were noted at similar elevations on both sides of high-angle faults, ruling out significant throw on these faults. The exposure of Late Cretaceous intrusive rocks near similar age volcanic units in the map area and the adjacent Mount Fairplay area further suggests vertical fault block movement occurred to juxtapose rocks from different depths since the Cretaceous.

\section{DIKES}

Granitic dikes with both aplitic and pegmatitic textures are common throughout the map area and are especially clustered in a few areas, including in the area surrounding Cretaceous granite $(\mathrm{Kg}$ in Wypych and others, 2021) intrusions near the Yukon border, as well as in the area surrounding Prindle Volcano, and on Hill 3916 west of McElfish Creek. These dikes are likely related to larger Cretaceous granite intrusions. The dikes were observed to be both concordant and discordant with foliation in metamorphic host rocks. Dikes sometimes appear to be folded within the Lake George assemblage. It is possible the dikes intruded along previously folded foliation planes. Weak foliation was rarely observed within the dikes. Dike orientations were similar in both aplite and pegmatite dikes and grouping by texture did not result in any preferred orientations. Both dike textures have similar geochemistry and are part of the same magmatic system. Aplite dikes were often crosscut by pegmatite dikes, indicating the pegmatite phase intruded later, but the two textures also were gradational in some instances, indicating close timing of intrusion. 
A muscovite ${ }^{40} \mathrm{Ar} /{ }^{39} \mathrm{Ar}$ age of $105.2 \pm 0.7$ $\mathrm{Ma}$ from a pegmatite dike is similar to metamorphic cooling ages of the host Lake George assemblage (Naibert and others, 2018), which suggests dike intrusion occurred before or during the mid-Cretaceous extension and uplift of the Lake George assemblage. Measured dike orientations fall into two broad populations: steeply dipping northsouth dikes and subhorizontal sills. About 30 percent of dikes do not fit well into either of these populations. The two populations both have better grouping before correction for foliation orientation of their host rocks than after unfolding (fig. 6). This indicates that dikes were likely intruded after ductile folding. The apparent folding of some dikes with the host metamorphic rocks may indicate that dike intrusion did overlap the end of ductile deformation or the apparent folded dikes resulted from intrusion along previously folded foliation planes.

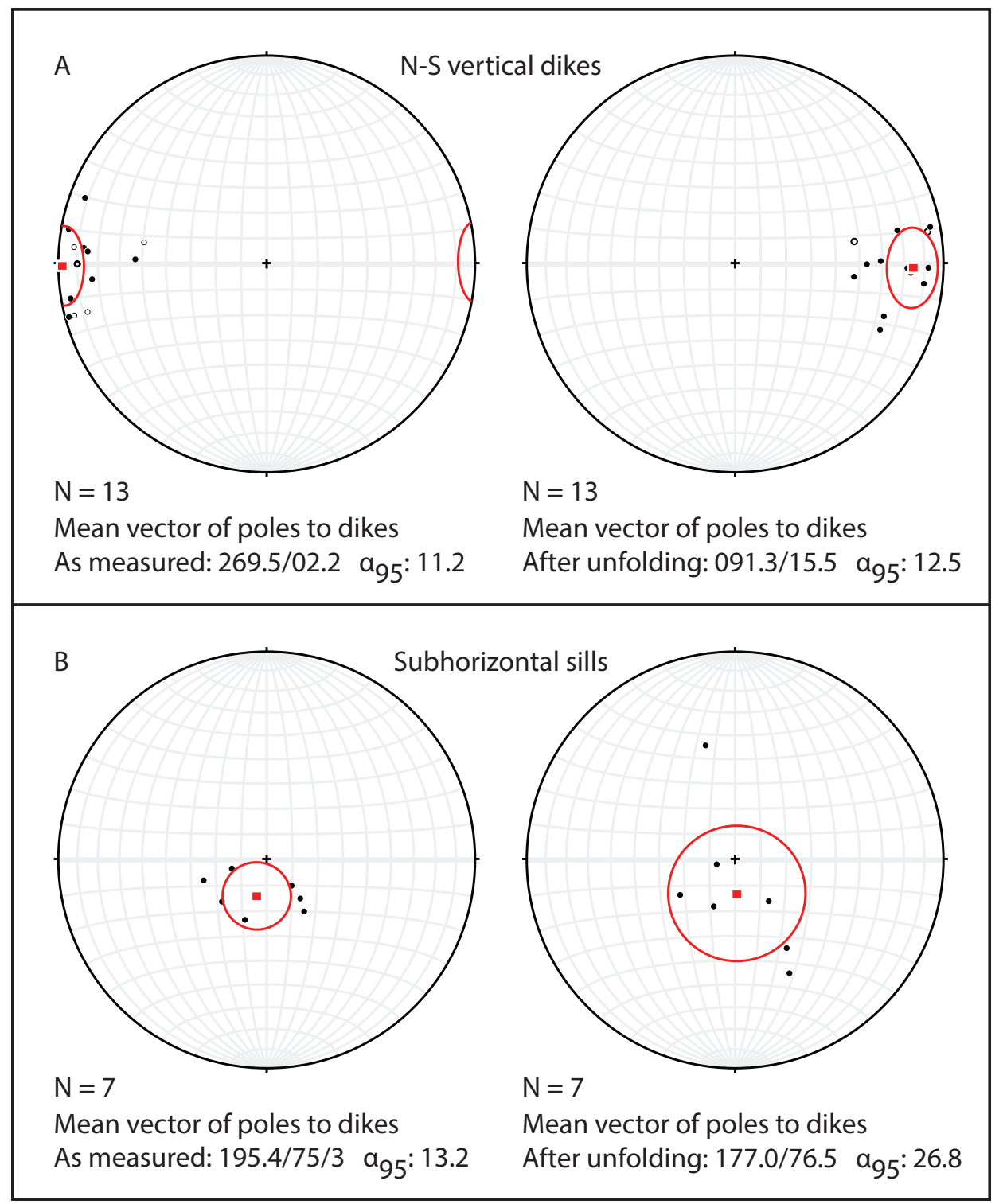

Figure 6. Lower hemisphere, equal-area stereonet plots of poles to two populations of measured dike planes as measured and after unfolding (using foliation measurements taken at the same outcrops). A. Data from a population of nearly vertical aplite and pegmatite dikes with north-south strikes. B. Data from a population of subhorizontal aplite and pegmatite sills. Closed circles indicate poles in the lower hemisphere and open circles indicate poles in the upper hemisphere. Mean vectors are reported with the half-apical angle of 95 percent confidence (a95). Measurements from both populations are more clustered as measured than after unfolding, indicating that folding in the host rocks occurred prior to dike intrusion. 


\section{ACKNOWLEDGMENTS}

The authors would like to thank the DGGS Mineral Resource Group and DGGS staff who contributed to this data collection, scientific discussions, and other necessary support. We thank Sean Regen and Bob Gillis for helpful reviews and suggestions to improve the manuscript. The DGGS Northeast Tanacross project was funded by State of Alaska general funds and the USGS National Cooperative Geologic Mapping Program under STATEMAP award number G18AC00137 for 2018. The views and conclusions contained in this document are those of the authors and should not be interpreted as necessarily representing the official policies, either expressed or implied, of the U.S. Government.

\section{REFERENCES}

Burns, L.E., Fugro Airborne Surveys Corp., and Fugro GeoServices, Inc., 2011, Ladue survey area: Magnetic and electromagnetic line, grid, and vector data and Maps, Fortymile mining district, Tanacross Quadrangle, eastern Alaska: Alaska Division of Geological \& Geophysical Surveys Geophysical Report 2011-1, 26 sheets, scale 1:63,360, 1 DVD. doi.org/10.14509/22562

Dusel-Bacon, Cynthia, Lanphere, M.A., Sharp, W.D., Layer, P.W., Hansen, V.L., 2002, Mesozoic thermal history and timing of structural events for the Yukon-Tanana Upland, east-central Alaska: ${ }^{40} \mathrm{Ar} /{ }^{39} \mathrm{Ar}$ data from metamorphic and plutonic rocks. Canadian Journal of Earth Sciences, v. 39, p. 1,013-1,051.

Emond, A.M., Saltus, R.W., Graham, Gina, and Goldak Airborne Surveys, 2015, Airborne magnetic geophysical survey of the Tanacross region, Alaska: Alaska Division of Geological \& Geophysical Surveys Geophysical Report 2015-6. doi.org/10.14509/29514

Foster, H.L., 1967, Geology of the Mount Fairplay area, Alaska: U.S. Geological Survey Bulletin, 1241-B, p. B1-B18, 1 sheet, scale 1:63,360.

Hansen, V.L., and Dusel-Bacon, Cynthia, 1998, Structural and kinematic evolution of the $\mathrm{Yu}-$ kon-Tanana upland tectonites, east-central Alaska: A record of late Paleozoic to Mesozoic crustal assembly: Geological Society of America Bulle- tin, v. 110 , p. $211-230$.

Jones III, J.V., Todd, Erin., Cain, J.S., Holm-Denoma, C.S., Ryan, J.J., Benowitz, J.A., 2017, Late Permian (ca. 267-257 Ma) magmatism, deformation, and metamorphism and lithotectonic associations of the Ladue River unit in east-central Alaska: Geological Society of America Abstracts with Programs, v. 49, no. 6.

Naibert, T.J., Benowitz, J.A., Wypych, Alicja, Sicard, K.R., and Twelker, Evan, 2018, ${ }^{40} \mathrm{Ar} /{ }^{39} \mathrm{Ar}$ data from the Tanacross D-1 and D-2, Big Delta B-4 and B-5, and Mount Hayes A-6 quadrangles, Alaska: Alaska Division of Geological \& Geophysical Surveys Raw Data File 2018-3, 15 p. doi.org/10.14509/30112

Naibert, T.J., Benowitz, J.A., Wypych, Alicja, Sicard, K.R., and Twelker, Evan, 2020, ${ }^{40} \mathrm{Ar} /{ }^{39} \mathrm{Ar}$ data from the Tanacross D-1 and parts of the D-2, C-1, and C-2 quadrangles, Alaska: Alaska Division of Geological \& Geophysical Surveys Raw Data File 2020-12, 35 p. doi. org/10.14509/30466

Naibert, T.J., Wypych, Alicja, and Twelker, Evan, 2021, Chapter C: Metamorphic cooling history of the Fortymile River and Lake George assemblages from ${ }^{40} \mathrm{Ar} /{ }^{39} \mathrm{Ar}$ geochronology from the northeast Tanacross and southeast Eagle quadrangles, Alaska, in Wypych, Alicja, Northeast Tanacross geologic mapping project, Alaska: Alaska Division of Geological \& Geophysical Surveys Report of Investigation 2020-9C. doi. org/10.14509/30540

Sánchez, M.G., Allan, M.M., Hart, C.J., Mortensen, J.K., 2014, Extracting ore-deposit-controlling structures from aeromagnetic, gravimetric, topographic, and regional geologic data in western Yukon and eastern Alaska. Interpretation, v. 2, no. 4, p. SJ75-SJ 102.

Werdon, M.B., Newberry, R.J., and Szumigala, D.J., 2001, Bedrock geologic map of the Eagle A-2 Quadrangle, Fortymile mining district, Alaska: Alaska Division of Geological \& Geophysical Surveys Preliminary Interpretive Report 2001-3B, 1 sheet, scale 1:63,360. doi. org/10.14509/2670 
Wilson, F.H., Hults, C.P., Mull, C.G., and Karl, S.M., 2015, Geologic map of Alaska: U.S. Geological Survey Scientific Investigations Map 3340, 197 p., 2 sheets, scale 1:1,584,000.

Wypych, Alicja, Hubbard, T.D., Naibert, T.J., Athey, J.E., Newberry, R.J., Sicard, K.R., Twelker, Evan, Werdon, M.B., Willingham, A.L., Wyatt, W.C., and Lockett, A.C., 2021, Chap- ter B: Northeast Tanacross geologic map and map units and descriptions, in Wypych, Alicja, Northeast Tanacross geologic mapping project, Alaska: Alaska Division of Geological \& Geophysical Surveys Report of Investigation 20209B. doi.org/10.14509/30539 


\section{CHAPTER E: GEOCHEMICAL INTERPRETATION OF SAMPLES OF IGNEOUS ROCKS FROM NORTHEAST TANACROSS}

Alicja Wypych ${ }^{1}$

\section{INTRODUCTION}

During a span of two summer field seasons in 2017 and 2018 geologists from the Alaska Division of Geological \& Geophysical Surveys (DGGS) carried out a geologic mapping and geochemical sampling project in the northeast Tanacross map area. Modern, high quality geochemical data were collected for 490 samples. This report focuses on the igneous subset of the samples collected, which are split into five major groups based on crystallization ages (Andronikov and Mukasa, 2010; Blondes and others, 2007; Todd and others, 2019; Wypych and others, 2020b), geochemical composition, and textural differences: 1) Triassic granites and granodioritic porphyries, 2) mid-Cretaceous granites and pegmatites, 3) Late Cretaceous dioritic to granitic porphyries, 4) Late Cretaceous andesite to rhyolite volcanic rocks, and 5) Quaternary basalts to basaltic trachyandesites (figs. 1, 2A and 2B). Petrological and geochemical investigations further distinguished igneous rock types associated with mineral occurrences as described in chapter F (Twelker and Newberry, 2021). Intrusive suites include the ca. $205 \mathrm{Ma}$ Witherspoon porphyry, ca. $110 \mathrm{Ma}$ granite and pegmatite, ca. 110 Timber pluton, suspected ca. 110 Fred granite, ca. $70 \mathrm{Ma}$ Taurus granodiorite, ca. $70 \mathrm{Ma}$ quartz-feldspar porphyry, and ca. $70 \mathrm{Ma}$ Pika diorite (Wypych and others, 2018) all of which are shown on the total alkali $\left(\mathrm{Na}_{2} \mathrm{O}+\mathrm{K}_{2} \mathrm{O}\right)$ versus silica $\left(\mathrm{SiO}_{2}\right)$ diagram (TAS) for intrusive rocks (fig. 2A; Cox and others, 1979; Wilson, 1989). The plutonic rocks exhibit a range of intermediate to felsic compositions. As with the intrusive suites, the volcanic rocks have a broad composition ranging from mafic to silicic $\left(\mathrm{SiO}_{2}\right.$ from 43 to $\left.76 \mathrm{wt} . \%\right)$ illustrated on the TAS diagram for volcanic rocks (fig. 2B; LeBas and others 1986), and are divided into two groups: ca. $70 \mathrm{Ma}$ volcanic flows and $176 \mathrm{ka}$ basanites.

All major and trace element compositions used in this report can be obtained as raw data files (Wypych and others, 2017; Wypych and others, 2018). A supplemental spreadsheet that relates map units to samples from the geochemical reports used for this interpretation can be download from doi.org/10.14509/30542. See Wypych and others (2017, doi.org/10.14509/29778; 2018, doi.org/10.14509/30113) for full documentation of the sample collection, preparation, and analytical methods.

\section{GEOLOGIC BACKGROUND}

Previous geologic investigations in the eastern Yukon Tanana Uplands region suggest periods of Triassic to Paleocene igneous activity (Foster, 1970, 1967; Gill, 1977; Harrington, 2010; Werdon and others, 2001; Szumigala and others, 2002). Foster (1970) describes the presence of felsic lavas, tuffs, tuff breccias, pumice-breccias, volcanic conglomerates and tuffaceous sediments as well as mafic lavas, breccias and tuffs in the region, and assigned them a Tertiary age based on pollen fossils found in the sedimentary units. Along with the Tertiary volcanic rocks, Foster (1970) describes equigranular to porphyritic diorite to granite intrusions of Mesozoic age. Gill (1977) conducted a detailed study of the area around the Pika and Fishhook prospects and described the presence of diorite, monzodiorite and monzonite, granodiorite, gabbro, multiple andesitic volcanic rocks, and basalt, all presumed to be Early Tertiary age. Harrington (2010) compiled previous industry reports focused on the Taurus prospect area and described Cretaceous granodiorite, along with

${ }^{1}$ Alaska Division of Geological \& Geophysical Surveys, 3354 College Rd., Fairbanks, Alaska 99709-3707. 


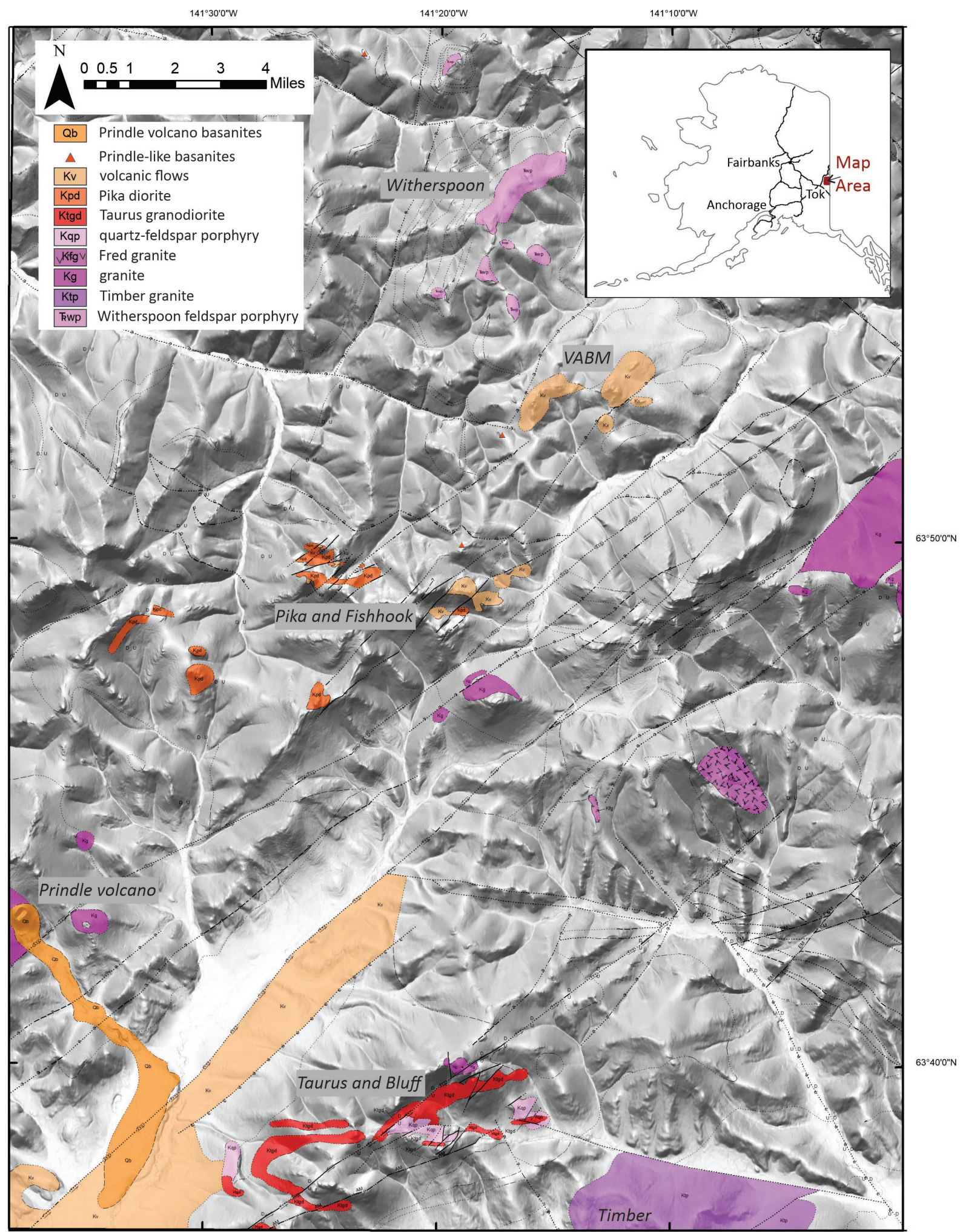

Figure 1. Geographic distribution of igneous units in the northeastern Tanacross map area (Wypych and others, 2021, sheet 1). — Kwp —Witherspoon feldspar porphyry; Ktp—Timber granite; Kg—granite; Kfg—Fred granite; Kqp— quartz-feldspar porphyry; Ktgd—Taurus granodiorite; Kpd—Pika diorite; Kv—volcanic flows; Qb—Prindle volcano and Prindle-like basanites. Thin dotted, dashed, and continuous fine lines signify unit contacts; thicker dotted, dashed, and continuous lines represent faults. 
Tertiary quartz monzonite porphyry, feldspar-quartz porphyry, quartz latite, quartz porphyry, intrusive breccia, and dacite. Here we compile, modify, and simplify these previous findings based on the research conducted by DGGS.

\section{TRIASSIC INTRUSIONS}

The oldest weakly metamorphosed to unmetamorphosed igneous rocks in the area are Triassic granites and granodioritic porphyries of the Witherspoon feldspar porphyry (kwp, fig. 1). This unit includes feldspar-rich dikes, plugs, and intrusions, with abundant chlorite and epidote alteration and slight foliation. They are granodioritic to granitic with $\mathrm{SiO}_{2}$ content between 65 and 74 wt.\%, some with elevated alkali contents (up to $8.5 \mathrm{wt} . \%$ total alkali) and one dioritic sample (fig. 2A). The samples are alkali-calcic to calc-alkalic, magnesian, and metaluminous to peraluminous (figs. 2C-E; Frost and others, 2001; Frost and Frost, 2008). The Witherspoon porphyry is characterized by relatively high strontium (Sr; up to 1300 parts per million [ppm]; fig. 3A) compared to other intrusions in the region, but lower concentrations of elements like lanthanum $(\mathrm{La})$, thorium $(\mathrm{Th})$, europium $(\mathrm{Eu})$ or ytterbium ( $\mathrm{Yb}$; figs. 3B-E). Relative to other intrusions in the region, this unit has lower rubidium $(\mathrm{Rb})$, yttrium $(\mathrm{Y})$, and niobium $(\mathrm{Nb})$ concentrations, which are typical of volcanic arc granitoids (fig. 3A; Pearce and others, 1984 ), and $\mathrm{Sr} / \mathrm{Y}$ ratios typical of adakitic melts (fig. 4E).

\section{MID-CRETACEOUS INTRUSIONS}

Mid-Cretaceous intrusions include the Timber granite pluton (Ktp), the Fred granite pluton $(\mathrm{Kfg})$ and other granite plutons and dikes (Kg; fig. 1). The units are generally coarse grained (up to pegmatitic), equigranular to porphyritic, and quartz rich, with biotite, minor hornblende, and accessory garnet. The granites all have greater than $70 \mathrm{wt} . \% \mathrm{SiO}_{2}$ and, in some cases, are enriched in alkalis (fig. 2A). Generally, the granites are calc-alkalic, ferroan (although the Timber granite does have a significant magnesian component), and peraluminous (figs. 2C-E). Trace element compositions of the granites are distinct from the Late Cretaceous and the Triassic intrusions, with lower $\mathrm{Sr}$ and zirconium $(\mathrm{Zr}$ ) concentrations (up to 473 and 477 ppm, respectively; figs. 3A and F). Fred granite has higher La concentration than the other mid-Cretaceous granites (fig. 3B); which are also characterized by low Eu concentrations (fig. 3D) typical of evolved rocks with plagioclase fractionation. On tectonic discrimination diagrams, the mid-Cretaceous samples are consistent with a volcanic arc origin, but some within-plate and syn-collisional affinity are also indicated (fig. 4B).

\section{LATE CRETACEOUS IGNEOUS ROCKS}

Late Cretaceous igneous rocks are divided into Taurus granodiorite (Ktgd) and quartz-feldspar porphyry (Kqp), Pika diorite (Kpd), and several occurrences of volcanic flows $(\mathrm{Kv})$ within the mapped area (fig. 1).

The Taurus granodiorite and Pika diorite have similar ages and are both porphyritic, medium-grained intrusive rocks characterized by the presence of hornblende. Tourmaline alteration is present in both, but more common in Taurus granodiorite. Taurus granodiorite has a tight range of $\mathrm{SiO}_{2}$ compositions between 64 and $70 \mathrm{wt} . \%$ (one outlier sample could be silicified, fig. 2A), whereas Pika diorite has a wide range of $\mathrm{SiO}_{2}$ compositions between 56 and 68 wt.\% (fig. 2A). Both the granodiorite and diorite are mostly calc-alkalic, magnesian, and metaluminous (with few exceptions, figs. 2C-E). The differences in silica concentration correlate with differences in trace element compositions, particularly the rare earth elements (figs. 3B-D). The Taurus granodiorite follows a separate fractionation trend than the Pika diorite, which is particularly well-highlighted by the $\mathrm{SiO}_{2}$ vs. Eu plot (fig. 3D) and has elevated $\mathrm{La}$, and $\mathrm{Rb}$ (figs. $3 \mathrm{~B}$ and F, fig. $4 \mathrm{C}$ and $\mathrm{D}$ ). Both the Taurus and Pika intrusions have volcanic arc granitoid signatures (figs. $4 \mathrm{C}$ and D).

A second distinctive intrusion in the Taurus area is the quartz porphyry (Kqp). This rock has a ca. 68 to 70 Ma crystallization age similar to the Taurus 

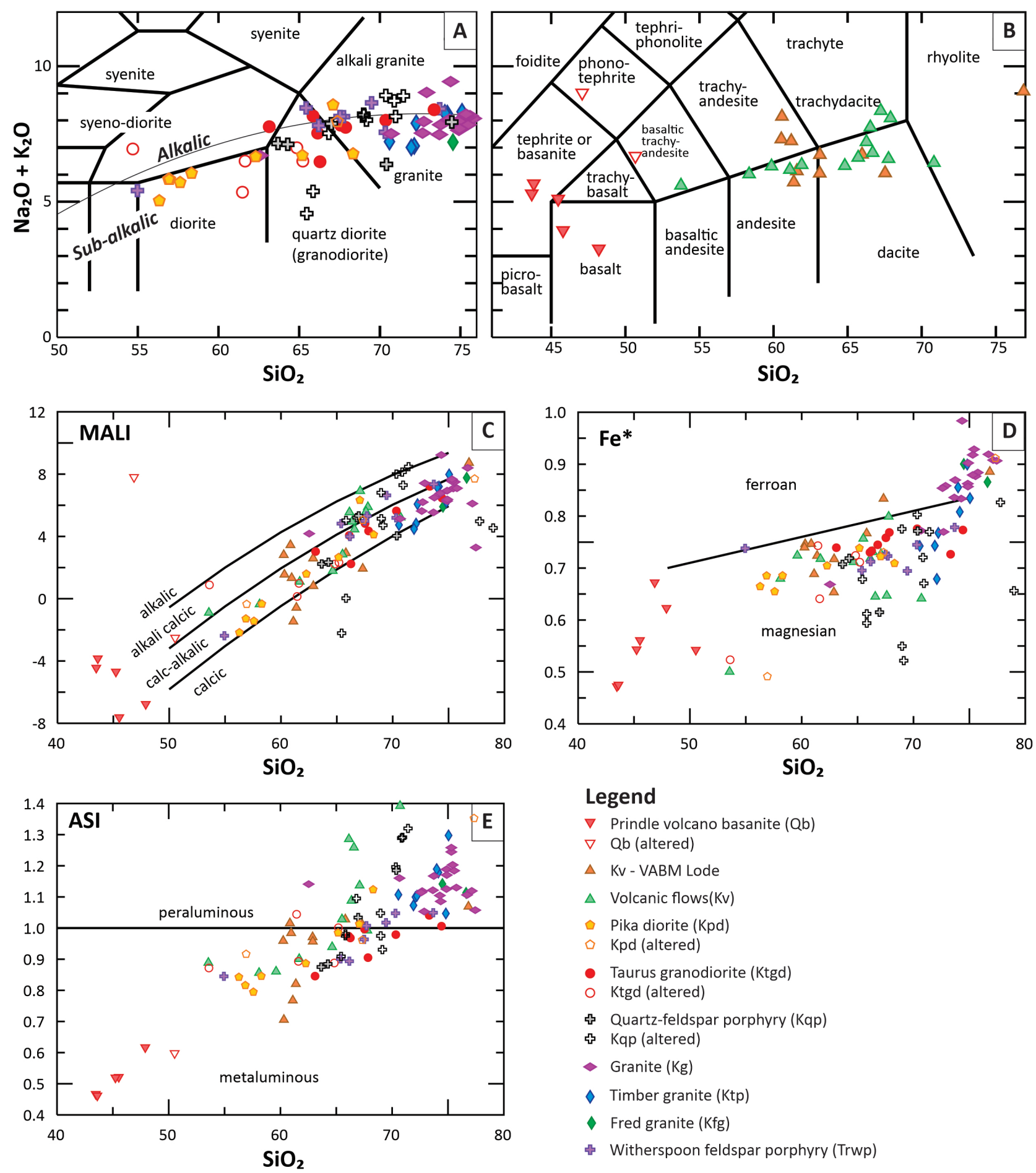

Legend

$\nabla$ Prindle volcano basanite (Qb)

$\nabla \mathrm{Qb}$ (altered)

$\triangle \mathrm{Kv}$ - VABM Lode

$\triangle$ Volcanic flows(Kv)

- Pika diorite (Kpd)

- Kpd (altered)

- Taurus granodiorite (Ktgd)

- Ktgd (altered)

\& Quartz-feldspar porphyry (Kqp)

↔ Kqp (altered)

- Granite (Kg)

$\checkmark$ Timber granite (Ktp)

$\checkmark$ Fred granite (Kfg)

* Witherspoon feldspar porphyry (Trwp)

Figure 2. Classification diagrams for igneous rocks from northeast Tanacross map area. A. Total alkali versus silica diagram with fields (labeled after Wilson, 1989) showing the compositional range of the plutonic rocks. B. Total alkali versus silica diagram with fields (after LeBas and others, 1986) showing the compositional range of the volcanic rocks. C. Modified alkalilime index (MALI $=\mathrm{Na}_{2} \mathrm{O}+\mathrm{K}_{2} \mathrm{O}-\mathrm{CaO}$; Frost and others, 2001). D. $\mathrm{Fe}^{*}=\left(\mathrm{FeO}_{\mathrm{tot}}\right) /\left(\mathrm{FeO}_{\mathrm{tot}}+\mathrm{MgO}\right)$; Frost and others, 2001). E. Aluminum saturation index diagram; $\mathrm{ASI}=\mathrm{Al} /(\mathrm{Ca}-1.67 \mathrm{P}+\mathrm{Na}+\mathrm{K})$; Frost and others, 2001). Oxide data have been normalized to 100 percent anhydrous. Open symbols signify samples described (in the field by the collector) as "altered;" Closed symbols represent samples described as "unaltered" or "fresh." 

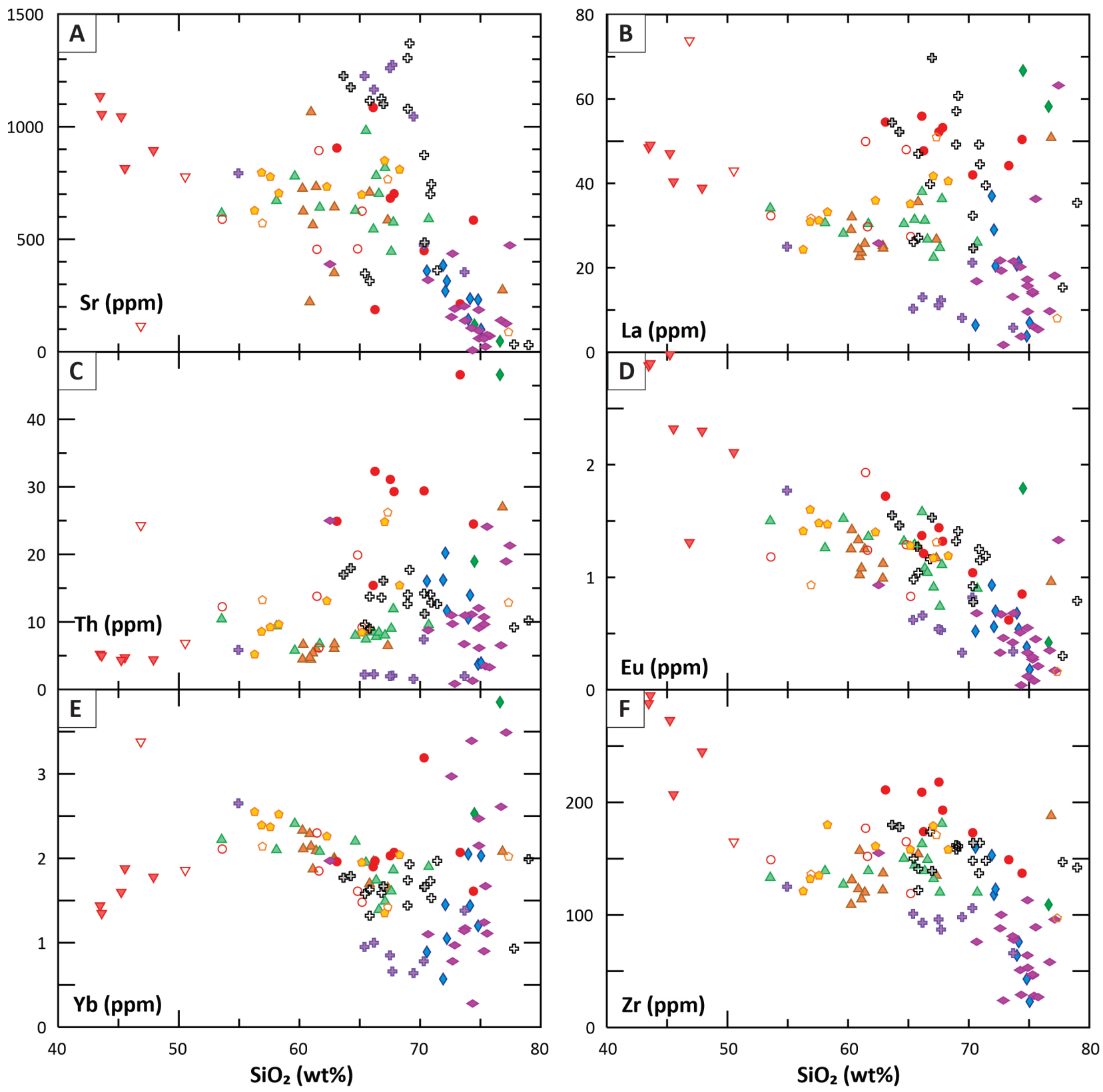

Figure 3. Bivariate plots of $\mathrm{SiO}_{2}$ (wt.\%) vs selected trace element abundances (ppm). Symbols and colors as in figure 2.

granodiorite (Todd and others, 2019). Based on relationships observed in hand samples we interpret this intrusion to be older than the granodiorite. This porphyry is fine grained, has phenocrysts of quartz, and is often highly altered to sericite. The samples with the least amount of alteration are of granodioritic to granitic composition (with 64 to $75 \mathrm{wt} . \%$ $\mathrm{SiO}_{2}$, fig. 2A), but the altered samples have elevated $\mathrm{K}_{2} \mathrm{O}$ and $\mathrm{Na}_{2} \mathrm{O}$ suggesting potassic and sodic alteration. The quartz porphyry is calc-alkalic, ferroan, and metaluminous to peraluminous (figs. 2C-E). Rare earth elements in the quartz porphyry are indistinguishable from the Taurus granodiorite (figs. 3B-E), but both $\mathrm{Th}$ and $\mathrm{Zr}$ concentrations are lower in the porphyry than in the granodiorite (figs. 3C and F) whereas Sr is generally higher (fig. 3A). The porphyry is of volcanic arc provenance and is similar to the Taurus granodiorite in the $\mathrm{Rb}$ vs $\mathrm{Y}+\mathrm{Nb}$ plot (fig. 4C). Some Taurus granodiorite samples have higher $\mathrm{Nb}$ and $\mathrm{Y}$ concentration (fig. 4C). 

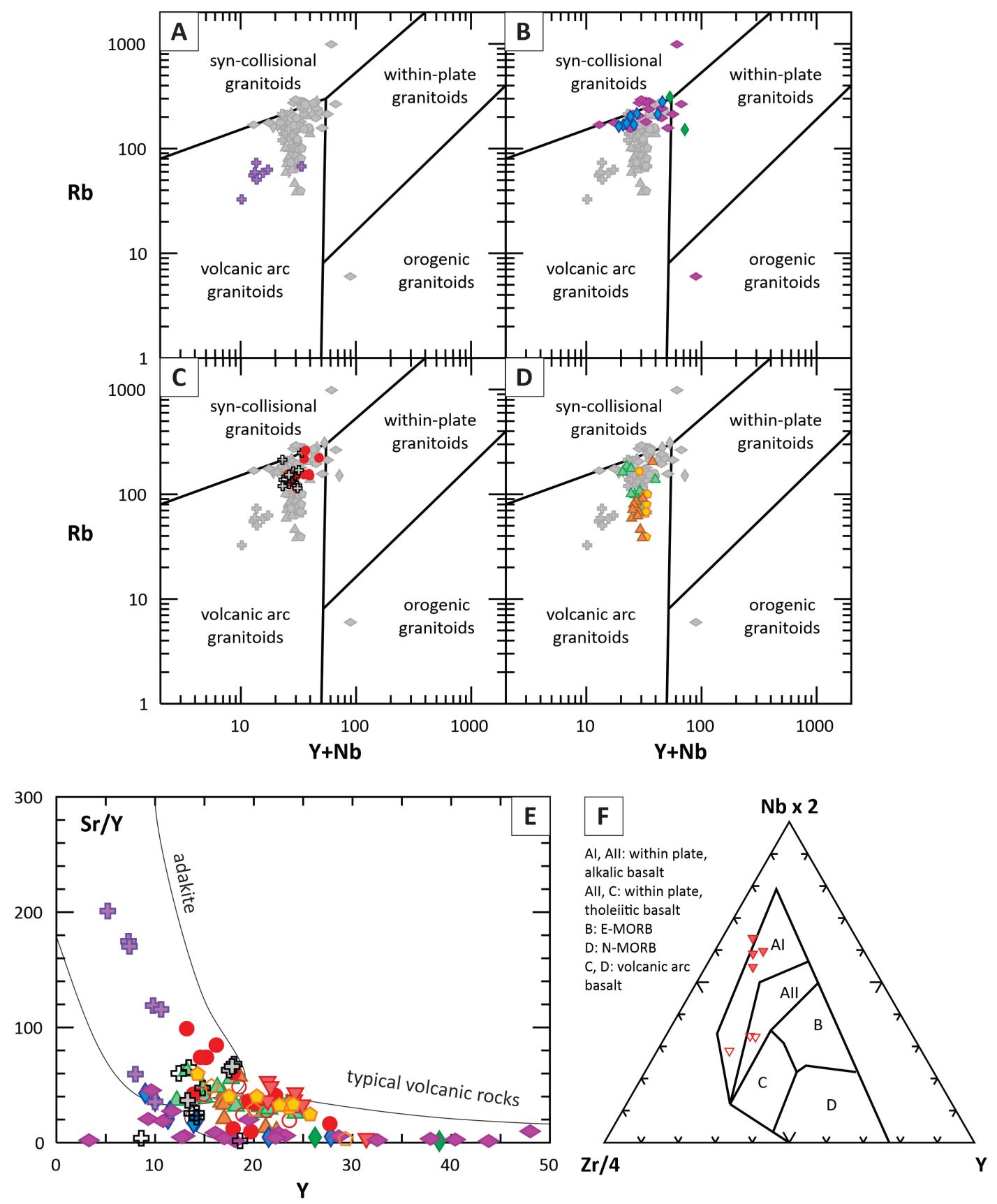

Figure 4. Tectonic classification diagrams for igneous rocks from the northeastern Tanacross area after Pearce and others (1984) for A. Witherspoon porphyry rocks; B. mid-Cretaceous granites; C. Taurus area intrusive rocks; and D. Pika-Fishhook area and VABM Lode volcanic rocks and the Pika diorite; E. Y versus Sr/Y bivariate diagram after Defant and others (1991); F. High field-strength element, tectonic discrimination ternary diagram for basalts (after Meschede,1986). Symbols and colors as in figure 2.

The volcanic flows observed in the Pika-Fishhook area and at VABM Lode are porphyritic with aphanitic matrix and feldspar phenocrysts, and are generally more siliceous than the Pika dioritespanning from andesite to dacite, with one basaltic sample and a couple of rhyolitic samples (fig. 2B).
Some samples have elevated alkali concentration, plotting them in trachyandesitic to trachydacitic fields on the TAS diagram (fig. 2B). The samples are calc-alkalic to alkali-calcic, mostly ferroan, and span between metaluminous and peraluminous (figs. 3C-E). In terms of trace element composi- 
tion, the volcanic rocks are indistinguishable from the Pika diorite (figs. 3A-F). On the Pearce (1984) diagram they lie along the same trend. One difference between them is that the volcanic rocks have slightly lower $\mathrm{Y}$ and $\mathrm{Nb}$ concentrations compared to the Pika diorite (fig. 4D). The similar trace element compositions of igneous rocks in the Pika-Fishhook area, the general major-element trend, and the proximity to the diorite lead us to believe that the volcanic rocks are an extrusive equivalent of the intrusive Pika diorite.

\section{QUATERNARY BASANITES OF PRINDLE VOLCANO}

The basanite of Prindle volcano (fig. 1) is a porphyritic black rock with aphanitic matrix and olivine phenocrysts. Samples are often vesicular and are characterized by the presence of numerous peridotitic and granulite xenoliths (Foster and others, 1966). Rocks with similar chemical composition and textural characteristics to the Prindle basanite have been observed further north in the map area and are included in the Prindle Volcano basanite unit for simplicity (fig. 1). Most of the samples analyzed are trachybasaltic to basanitic on the TAS diagram (fig. 2B), with few basaltic samples present. The basanites have a distinctive trace element composition, with very low $\mathrm{Th}$ and $\mathrm{Yb}$ concentration (figs. $3 \mathrm{C}$ and $\mathrm{E}$ ) and high Sr, La, Eu, and Zr (figs. 3A, B, D, and F). The majority of samples are of within-plate alkalic basalt affinity, with a couple tholeiitic within-plate basalts (Meschede, 1986; fig. 4F).

\section{CONCLUSIONS}

The magmatic activity in the Northeast Tanacross map area spans from Triassic to Quaternary and, apart from Prindle basanites, seems to be derived from volcanic arc activity (figs. $4 \mathrm{~A}-\mathrm{D}$ ). The magne- sian signature of mafic to intermediate Triassic and Late Cretaceous samples supports magma genesis under oxidized conditions (Frost and Frost, 2008), and elevated $\mathrm{Sr} / \mathrm{Y}$ ratios with relatively low La/ $\mathrm{Yb}$ suggest partial melting of lower crust (Moyen, 2009) or contamination with upper crust material. The mid-Cretaceous granites, similar to the other magmatic rocks in the region, have a volcanic arc affinity (fig. 4B), however, the elevated $\mathrm{Rb}$ and $\mathrm{Al}_{2} \mathrm{O}_{3}$, (figs. $4 \mathrm{~B}$ and $2 \mathrm{E}$ ) suggest crustal melt input. Longer residency in the crust suggested by presence of an Eu anomaly (Wypych and others, 2017, 2018) could facilitate significant crustal melt input in the magma chamber. Finally, the volcanic rocks of Prindle volcano have a separate melt origin that indicates a deep, more-fertile magma source and is consistent with the presence of fertile mantle xenoliths (Todd, 2019, personal commun.) and within-plate tectonic affinity (fig. 4F).

\section{ACKNOWLEDGMENTS}

The author would like to thank the DGGS Mineral Resources section and DGGS staff who contributed to the data collection, scientific discussions and other necessary support. The DGGS Northeast Tanacross project was primarily funded by State of Alaska general funds, with supplementary funding from the USGS National Cooperative Geologic Mapping Program under STATEMAP award number G18AC00137 for 2018. The views and conclusions contained in this document are those of the authors and should not be interpreted as necessarily representing the official policies, either expressed or implied, of the U.S. Government.

The author would like to thank Dr. Erin Todd and Robert Gillis for providing insightful discussion and contributing to the accuracy of this report. 


\section{REFERENCES}

Andronikov, A.V., and Mukasa, S.B., 2010, ${ }^{40} \mathrm{Ar} /{ }^{39} \mathrm{Ar}$ eruption ages and geochemical characteristics of Late Tertiary to Quaternary intraplate and arcrelated lavas in interior Alaska: Lithos, v. 115, no. $1-4$, p. $1-14$.

Blondes, M.S., Reiners, P.W., Edwards, B.R., and Biscontini, Adrian, 2007, Dating young basalt eruptions by $(\mathrm{U}-\mathrm{Th}) / \mathrm{He}$ on xenolithic zircons: Geology, v. 35, no. 1, p. 17-20.

Cox, K.G., Bell, J.D., and Pankhurst, R.J., 1979, The Interpretation of Igneous Rocks: Allen and Unwin, London.

Defant, M.J., Richerson, P.M., DeBoer, J.Z., Stewart, R.H., Maury, R.C., Bellon, H., Drummond, M.S., Feigenson, M.D., Jackson, T.E., 1991, Dacite genesis via slab meltingand differentiation: petrogenesis of La Yeguada volcanic complex, Panama: Journal of petrology v. 42, p. 1,101-1,142.

Foster, H.L., 1967, Geology of the Mount Fairplay area, Alaska: U.S. Geological Survey Bulletin 1241-B, p. B1-B18.

1970, Reconnaissance Geologic Map of the Tanacross Quadrangle, Alaska: U.S. Geological Survey Miscellaneous Geologic Investigations Map 593, 1 sheet, scale 1:250,000.

Foster, H.L., Forbes, R.B., and Ragan, D.M., 1966, Granulite and peridotite inclusions from Prindle Volcano, Yukon-Tanana Upland, Alaska, U.S. Geological Survey Professional Paper 550-B, p. B115-B119.

Frost, B.R., Barnes, C.G., Collins, W.J., Arculus, R.J., Ellis, D.J., and Frost, C.D., 2001, A geochemical classification for granitic rocks: Journal Of Petrology, v. 42, no. 11, p. 2033-2048.

Frost, B.R., and Frost, C.D., 2008, A Geochemical Classification for Feldspathic Igneous Rocks: Journal of Petrology, v. 49, no. 11, p. 1955-1969.

Gill, R.D., 1977, Geology and mineral deposits of the southwest quarter of the Tanacross D-1 quadrangle, Alaska: Golden, Colorado School of Mines, M.Sc. thesis, 129 p.

Harrington, Edward, 2010, Taurus Property: Technical Report for Senator Minerals Inc., 133 p. (posted on www.sedar.com)
LeBas, M.J., LeMaitre, R.W., Streckeisen, A., and Zanettin, B., 1986, A Chemical Classification of Volcanic Rocks Based on the Total AlkaliSilica Diagram: Journal of Petrology, v. 23, no. 3, p. $745-750$.

Meschede, Martin, 1986, A method of discrimination between different types of mid-ocean ridge basalts and continental tholeiites with the $\mathrm{Nb}-\mathrm{Zr}-\mathrm{Y}$ diagram: Chemical Geology, v. 56, p. 207-218.

Moyen, J.-F., 2009, High Sr/Y and La/Yb ratios: The meaning of the "adakitic signature": Lithos, v. 112 , no. 3-4, p. 556-574.

Pearce, J.A., Harris, N.B., and Tindle, A.G., 1984, Trace element discrimination diagrams for the tectonic interpretation of granitic rocks: Journal of Geophysical Research, v. 103, p. 7,171-7,186.

Szumigala, D.J., Newberry, R.J., Werdon, M.B., Athey, J.E., Stevens, D.S.P., Flynn, R.L., Clautice, K.H., and Craw, P.A., 2002, Geologic map of the Eagle A-1 Quadrangle, Fortymile mining district: Alaska Division of Geological \& Geophysical Surveys Preliminary Interpretive Report 2002-1A, 1 sheet, scale 1:63,360. doi. org/10.14509/2863

Todd, Erin, Wypych, Alicja, and Kylander-Clark, Andrew, 2019, U-Pb and Lu-Hf isotope, age, and trace element data from zircon separates from the Tanacross D-1, and parts of D-2, C-1 , and C-2 quadrangles: Alaska Division of Geological \& Geophysical Surveys Raw Data File 2019-5, 10 p. Twelker, Evan, and Newberry, R.J., 2021, Chapter F: Observations on the economic geology of the northeast Tanacross map area, in Wypych, Alicja, Northeast Tanacross geologic mapping project, Alaska: Alaska Division of Geological \& Geophysical Surveys Report of Investigation 20209F. doi.org/10.14509/30557

Werdon, M.B., Newberry, R.J., Szumigala, D.J., and Pinney, D.S., 2001, Geologic map of the Eagle A-2 Quadrangle, Fortymile mining district, Alaska: Alaska Division of Geological \& Geophysical Surveys Preliminary Interpretive Report 2001-3A, 1 sheet, scale 1:63,360, v. 1.0.1. doi.org/10.14509/2669 
Wilson, Marjorie, 1989, Igneous petrogenesis: Unwin Hyman, London, 466 p.

Wypych, Alicja, Hubbard, T.D., Naibert, T.J., Athey, J.E., Newberry, R.J., Sicard, K.R., Twelker, Evan, Werdon, M.B., Willingham, A.L., Wyatt, W.C., and Lockett, A.C., 2021, Chapter B: Northeast Tanacross geologic map and map units and descriptions, in Wypych, Alicja, Northeast Tanacross geologic mapping project, Alaska: Alaska Division of Geological \& Geophysical Surveys Report of Investigation 2020-9B. doi.org/10.14509/30539

Wypych, Alicja, Jones, J.V., III, and O'Sullivan, P., 2020b, U-Pb zircon ages from bedrock samples collected in the Tanacross D-1, and parts of D-2, C-1 and C-2 quadrangles, Alaska : Alaska Division of Geological \& Geophysical Surveys Preliminary Interpretive Report 2020-2, 19 p. doi.org/10.14509/30465
Wypych, Alicja, Naibert, T.J., Athey, J.E., Newberry, R.J., Sicard, K.R., Twelker, E., Werdon, M.B., Willingham, A.L., and Wyatt, W.C., 2018, Major-oxide and trace-element geochemical data from rocks collected in 2018 for the Northeast Tanacross project, Tanacross C-1, C-2, D-1, and D-2 quadrangles, Alaska: Alaska Division of Geological \& Geophysical Surveys Raw Data File 2018-4, 4 p. doi.org/10.14509/30113

Wypych, Alicja, Twelker, E., Athey, J.E., Lockett, A.C., Naibert, T.J., Sicard, K.R., Werdon, M.B., and Willingham, A.L., 2017, Major-oxide and trace-element geochemical data from rocks collected in the Tanacross C-1, D-1, and D-2 quadrangles, Alaska in 2017: Alaska Division of Geological \& Geophysical Surveys Raw Data File 2017-10, 4 p. doi.org/10.14509/29778 


\section{CHAPTER F: OBSERVATIONS ON THE ECONOMIC GEOLOGY OF NORTHEAST TANACROSS}

Evan Twelker ${ }^{1}$ and Rainer J. Newberry ${ }^{2}$

\section{INTRODUCTION}

The known and potential mineral resources of the Northeast Tanacross map area include minor placer gold and a variety of prospects that are likely related to one or more porphyry copper-gold-molybdenum (Cu-Au-Mo) systems. The best-defined lode mineralization is located in the TaurusBluff area (fig. 1), where exploration since 1970 has identified an inferred mineral resource of 68 million metric tons grading 0.275 percent $\mathrm{Cu}$, 324 ppm Mo, and 0.166 ppm Au at East Taurus (Harrington, 2010). Prospects and mineral occurrences also cluster in the Pika-Fishhook area (fig. 1). Mineralization in both areas appears to be magmatic-hydrothermal in origin and latest Cretaceous in age. An evaluation of the similarities and differences between the two prospect clusters is of particular interest in assessing the potential for as-yet undiscovered porphyry $\mathrm{Cu}-\mathrm{Mo}-\mathrm{Au}$ systems in the Pika-Fishhook area.

While the Taurus-Bluff area contains multiple intrusive phases, the mineralization appears to be associated with, and genetically related to, quartz-feldspar porphyry intrusions of granitic composition. Our fieldwork did not locate any intrusions of this composition at the surface in the Pika-Fishhook area, although they may occur at depth or under vegetative cover.

The Taurus-Bluff and Pika-Fishhook areas are somewhat similar in terms of the $\mathrm{Cu}$-poor styles of observed mineralization; mineralization enriched in either gold $\mathrm{Au}$ ) or silver-lead-bismuth-arsenic (Ag-Pb-Bi-As) occurs at both. Such mineralization could be the distal expression of porphyry $\mathrm{Cu}-\mathrm{Mo}-\mathrm{Au}$ systems. Further, both have broad alteration footprints consisting of locally developed sericite alteration, and potassic alteration occurs locally within the broader footprint. Tourmaline occurrences form notable clusters around each area; however, this pattern cannot be interpreted solely as alteration because our field observations include both pre- and post-metamorphic (latest Cretaceous?) tourmaline.

Placer gold, which has been mined at a small scale from Liberty Creek (fig. 1), could be interpreted as the southernmost locality of the Fortymile placer district, which concentrates Jurassic orogenic-type gold known to occur regionally in the Fortymile River Assemblage. However, given the lack of placer mining in nearby creeks (e.g., Dewey Creek) and the Liberty Creek placer's location downstream of the Fishhook prospect, placer gold is most likely sourced from intrusion-related mineralization in the Pika-Fishhook area. Alternatively, the gold could be re-sedimented from Late Cretaceous conglomerates mapped in the headwaters of Liberty Creek.

\section{INTRUSIVE ROCKS}

At the scale of our mapping, the Cretaceous intrusions in the Taurus-Bluff area are generalized into three groups: pre-mineralization peraluminous granite, syn-mineralization quartz-feldspar porphyry, and post-mineralization intrusions of granodiorite to quartz monzonite composition. In the Pika-Fishhook area, we mapped hypabyssal intrusions of diorite to granodiorite composition and volcanic flows of mostly andesitic composition.

\section{Granite (Unit Kg)}

The oldest of the post-metamorphic intrusions in the map area are broadly scattered dikes,

${ }^{1}$ Alaska Division of Geological \& Geophysical Surveys, 3354 College Rd., Fairbanks, Alaska 99709-3707.

${ }^{2}$ Department of Geosciences, University of Alaska, P.O. Box 755780, Fairbanks, Alaska 99775-5780 


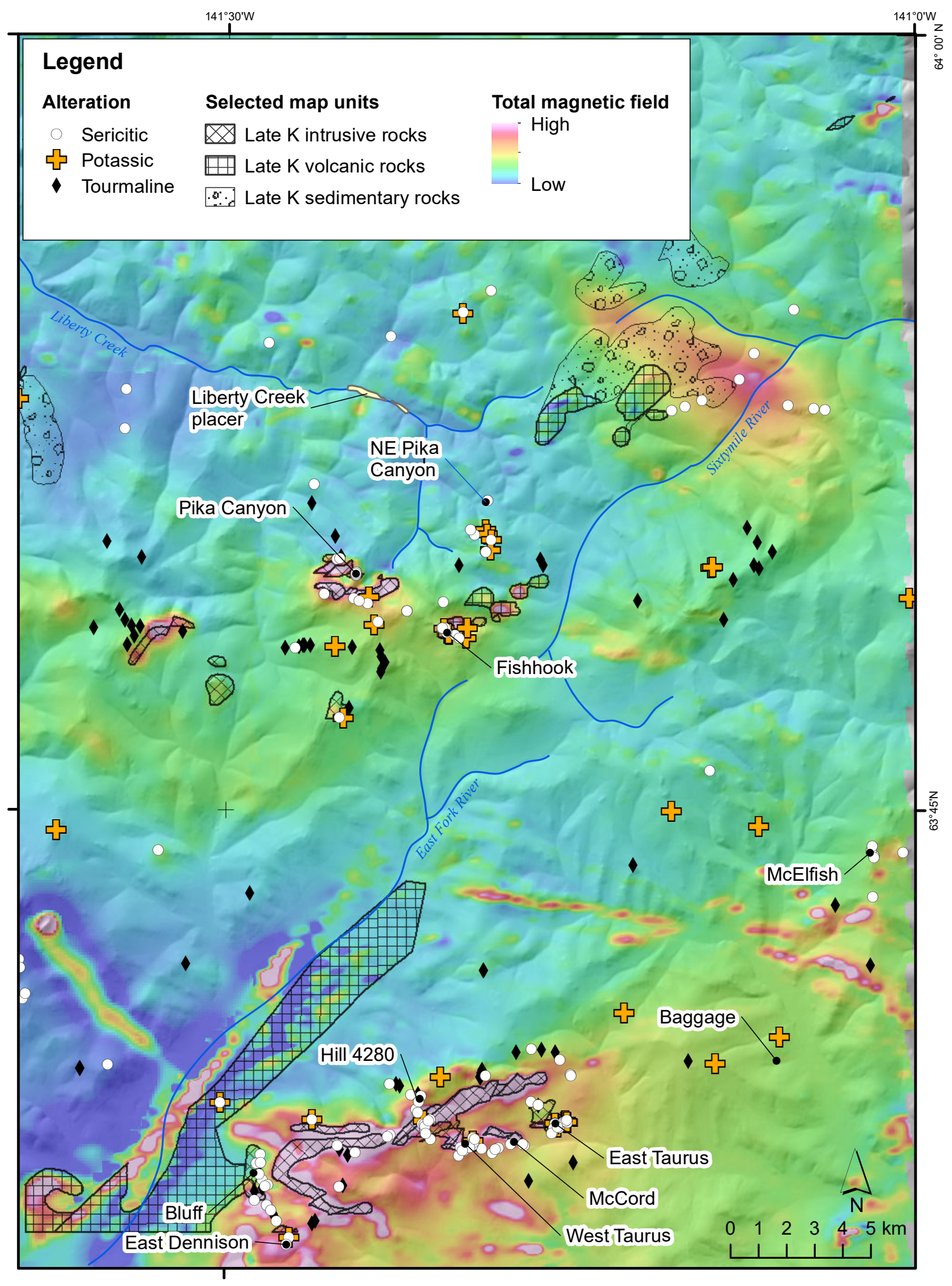

Figure 1. Map of the study area showing mineral prospects and occurrences (labeled), selected Late Cretaceous geologic units, and selected alteration assemblages based on DGGS field observations and geochemical data. Note that tourmaline occurrences include multiple events (pre-metamorphic and latest Cretaceous?) that we have not differentiated. The base map is a topographic hill shade image overlain by color-shaded simulated total magnetic field from airborne magnetic surveys of Burns and others (2011) and Emond and others (2015). 
sills, and stocks of locally garnet- or muscovite-bearing granite, aplite, and pegmatite. Intrusions of this type are most abundant in the area northeast of Taurus and southwest of Fishhook; the spatial distribution of this unit does not appear to have any relation to the distribution of the Late Cretaceous intrusions or the alteration footprints around Taurus-Bluff or Pika-Fishhook. This unit occurs as both sills intruding along foliation and dikes cutting foliation, and in some field exposures it appears to be strained; therefore, we infer that it was intruded during the final stages of regional metamorphism and deformation. ${ }^{40} \mathrm{Ar} /{ }^{39} \mathrm{Ar}$ dating of this intrusive suite in the map area yields Early Cretaceous ages around 105 to $110 \mathrm{Ma}$ (Naibert and others, 2018).

\section{Quartz-Feldspar Porphyry (Unit Kqp)}

One or more phases of intrusions that are most closely associated with $\mathrm{Cu}-\mathrm{Mo}-\mathrm{Au}$ mineralization at Taurus and Bluff are moderately to intensely altered but retain porphyry textures and relict quartz and feldspar phenocrysts. This unit also includes the strongly quartz-sericite-pyrite-altered intrusion breccias at the East Taurus camp and airstrip area. Whole-rock geochemical data indicate that the less-altered samples from this unit have 18-29 percent normative quartz out of total quartz and feldspar. They are therefore best described as granites. A molybdenite-bearing sample taken from this unit at West Taurus yielded $\mathrm{U}-\mathrm{Pb}$ zircon age of $70.6 \pm 0.9 \mathrm{Ma}$ (Todd and others, 2019), while Allan and others (2013) obtained a $\mathrm{U}-\mathrm{Pb}$ zircon age of $71.4 \pm 0.3 \mathrm{Ma}$ from altered and mineralized quartz feldspar porphyry at the Bluff prospect.

\section{Taurus Granodiorite (unit Ktgd)}

The youngest suite of intrusions in the TaurusBluffarea is significantly more mafic and has compositions from granodiorite to quartz monzonite (unit Ktgd; map sheet 1). Smaller dikes have porphyry textures (hornblende-feldspar porphyry), while a 200- to 500-meter-thick dike (true thickness) north of Taurus is medium grained and equigran- ular in texture. Mafic minerals include hornblende, biotite, and clinopyroxene. Magnetite is relatively abundant; the characteristically high magnetic susceptibility of this unit makes it easily mapped or modeled from aeromagnetic surveys, as shown in the magnetic modeling section of this report. This unit was intercepted by drilling in the heart of the East Taurus prospect (Kenorland Minerals, 2017) and displays only propylitic alteration; it is convincingly post-mineralization in timing. Wypych and others (2020) obtained a U-Pb zircon age of $71.0 \pm 1.1 \mathrm{Ma}$ from a sample of this unit from East Taurus; this age is within error of zircon ages from the syn-mineralization quartz-feldspar porphyry and indicates a compressed time frame for emplacement of the intrusive phases in the area.

\section{Pika Diorite (Unit Kpd)}

Our mapping in the Pika-Fishhook area found a single group of relatively shallowly emplaced intrusions having a compositional range of diorite to granodiorite (unit Kpd; map sheet 1). Textures depend on the size of the intrusive body and range from porphyry to medium-grained seriate or equigranular. Porphyry intrusions are characterized by plagioclase, hornblende, and biotite in an aphanitic groundmass, while holocrystalline samples are dominated by plagioclase, quartz, pyroxene, biotite, and hornblende. Up to 5 percent primary magnetite is present in most samples. U-Pb dating of this unit yielded ages of $70.3 \pm 0.5$ and 68.09 $\pm 0.94 \mathrm{Ma}$ for diorite and porphyry intrusions, respectively (Todd and others, 2019). Biotite from the Pika diorite yielded an ${ }^{40} \mathrm{Ar} /{ }^{39} \mathrm{Ar}$ plateau age of $66.3 \pm 0.7 \mathrm{Ma}$ (Naibert and others, 2018).

As discussed in chapter E (Wypych and others, 2020), the Pika diorite and the Taurus granodiorite are similar in geochemistry, mineralogy, and age, although the Pika diorite is somewhat more mafic in terms of major element geochemistry. The Pika diorite may also be more shallowly exposed given its smaller area of exposure and the presence of coeval andesitic volcanic flows in the immediate vicinity of Fishhook. 
PORPHYRY STYLE MINERALIZATION AND ALTERATION

The mineralization of greatest economic potential in the study area is the porphyry-type $\mathrm{Cu}-\mathrm{Mo}-\mathrm{Au}$ defined by drilling in the East Taurus area. Much of the surface exposure is characterized by weathered quartz-sericite-pyrite-altered material that comprises a leached cap of variable thickness extending in places to depths of 40 to 58 meters (Leriche, 1995). Recent drilling by Senator Minerals (drill hole T08-40) intercepted relatively un-leached mineralization (compared to the adjacent drill holes), hosted in potassic-altered intrusive rock, from a depth of 7.9 meters to the end of the hole at 440 meters (Harrington, 2010).

Our petrographic observations of East Taurus mineralization show that it occurs with the assemblage pyrite, chalcopyrite, molybdenite, magnetite, and local hematite. Pyrite locally contains inclusions of pyrrhotite and chalcopyrite. Mineralization occurs as hairline A-type veinlets, local B-veinlets, and as disseminated sulfides. Potassic alteration is mostly present as secondary biotite replacement of primary biotite and rare hornblende; it occurs only locally as potassium (K)-feldspar flooding. Weak to moderate sericitic and propylitic alteration comprising sericite, chlorite, calcite, epidote, and rutile variably overprint the potassic zone. Moderate sericitic alteration includes replacement of plagioclase phenocrysts by sericite, but residual primary or secondary biotite may remain. In pervasively sericitized samples, mafics may be altered to chlorite, epidote, and rutile; D-type pyrite-quartz veinlets, and 5 percent disseminated pyrite and trace chalcopyrite are typical of this assemblage. Tourmaline does not occur in any significant abundance within the immediate East Taurus resource area.

No core was available from the West Taurus prospect; however, our examination of variably weathered surface samples indicates that the geology may be similar to that of East Taurus.
Observed mineralization included disseminated and veinlet-hosted pyrite, chalcopyrite, magnetite, and molybdenite; pyrite locally contains inclusions of pyrrhotite and chalcopyrite. Samples collected for thin section show weak potassic alteration characterized by replacement of mafics by secondary biotite; rocks do not have high $\mathrm{K}_{2} \mathrm{O}$ bulk compositions or K-feldspar flooding. Potassic alteration is partially overprinted by sericitic alteration or a propylitic assemblage of chlorite, epidote, calcite, titanite, and sericite. The greater exposure of potassic alteration at surface plus the larger footprint of the soil geochemical anomalies (Leriche, 1995) may suggest a deeper level of exposure at West Taurus than at East Taurus.

Our examination of the Bluff prospect found several types of altered dikes or stocks, intrusive breccia, and well-developed quartz-sericite-pyrite alteration. Tourmaline occurs with sericitic alteration in both intrusive and metamorphic rocks. Surface samples are strongly weathered and may be leached of copper.

\section{OTHER STYLES OF MINERALIZATION AND ALTERATION}

We sampled mineralization at the East Dennison prospect, which lies about $2.5 \mathrm{~km}$ south of Bluff. Based on the observed texture and relict mineralogy of the altered intrusive rock we interpret that this prospect is hosted by feldspar-hornblende porphyry (granodiorite; unit Ktgd) overprinted by quartz-tourmaline veins and sericite-pyrite alteration. This mineralization has a $\mathrm{Ag}-\mathrm{Pb}-\mathrm{Bi}-\mathrm{As}-\mathrm{Sb}$ geochemical signature. Our mapping found similar Ag-enriched, tourmaline-associated mineralization elsewhere in the Taurus-Bluff area. It is unclear whether the distribution of this style of mineralization is controlled by intrusions, especially unit Ktgd, structures such as the Tourmaline fault of Leriche (1995), or a combination of both features.

We observed pervasive quartz-sericite-pyrite alteration of orthogneiss along $650 \mathrm{~m}$ of ridgeline at Hill 4280, about $2.5 \mathrm{~km}$ northwest of West Taurus. 
Samples from this zone carry weakly anomalous $\mathrm{Ag}, \mathrm{Bi}, \mathrm{Pb}$, and $\mathrm{Zn}$; however, one sample from this zone assayed $2.67 \mathrm{ppm} \mathrm{Au}$, plus weakly anomalous $\mathrm{Ag}, \mathrm{Bi}$, and $\mathrm{Te}$ (sample 18MBW082 of Wypych and others, 2018). This gold-mineralized sample is not anomalous in its content of sulfide and did not contain vug-bearing quartz veinlets that occur locally in the area.

Mineralization in the Pika and Fishhook area appears to be largely structurally controlled and hosted in veins, breccias, or in altered rocks close to mappable structures. Some mineralization is also hosted in altered intrusive rocks without evidence of a clear structural control. Gold is the most economically significant element at the Fishhook prospect. Our highest-grade sample carried $2.15 \mathrm{ppm} \mathrm{Au}$, plus $9.14 \mathrm{ppm} \mathrm{Bi}, 6$ ppm $\mathrm{Te}$, and $310 \mathrm{ppm} \mathrm{Cu}$ (sample 17MBW119 of Wypych and others, 2017). The sample is of faulted metamorphic rock carrying up to 5 percent iron oxide (after sulfide) occurring as both foliation-parallel bands and disseminations. The sample is one of about 20 in the area (fig. 1) where major element geochemistry yields higher than normal molar $\mathrm{K} / \mathrm{Al}$ ratios (0.5-0.7) suggesting potassic alteration. These samples are massive to mylonitic in texture, light in color, and dominated by fine-grained quartz and potassium feldspar (identified in hand sample with support of whole rock geochemistry). White mica and minor biotite are present in some samples. Gill (1977) also describes local potassic alteration; in this case within an intrusive stock at the Northeast Pika Canyon prospect. We sampled another style of mineralization about $200 \mathrm{~m}$ to the west of $17 \mathrm{MBW} 119$; this sample assayed $0.7 \mathrm{ppm} \mathrm{Au}$ associated with stockwork veinlets and pervasive sericitic alteration (17MBW130 of Wypych and others, 2017). We dated alteration sericite from a felsic dike at the Fishhook prospect, yielding an ${ }^{40} \mathrm{Ar} /{ }^{39} \mathrm{Ar}$ plateau age of $63.7 \pm 0.5 \mathrm{Ma}$ (Naibert and others, 2018).

We observed Ag-bearing veins and vein breccias at a few scattered locations within the broader Pika-Fishhook area. All of these were deeply oxidized, but from their gossanous appearance they apparently contained a sulfide-rich infill. One such sample, displaying relict banded sulfide textures, assayed $56.5 \mathrm{ppm} \mathrm{Ag}, 3.5$ percent $\mathrm{Pb}, 592 \mathrm{ppm} \mathrm{Sb}$, $422 \mathrm{ppm} \mathrm{Cu}$, and $323 \mathrm{ppm} \mathrm{Zn.} \mathrm{At} \mathrm{another} \mathrm{loca-}$ tion near the Pika prospect, approximately $1 \mathrm{~cm}$ thick, unoxidized, medium-grained galena veins are locally associated with druzy quartz and assay 4420 ppm Ag, 30 percent $\mathrm{Pb}$, and 3430 ppm Sb (sample 17MLW002 of Wypych and others, 2017). Silver mineralization also occurs in quartz-sericite-pyrite altered intrusive rocks (unit Kpd); one sample from the Pika prospect assayed $14.4 \mathrm{ppm} \mathrm{Ag}$ and 2070 ppm Pb (17ET008 of Wypych and others, 2017). Another sample of iron-stained, weakly altered intrusive rock from the Pika area assayed 0.175 ppm Au.

\section{ALTERATION FOOTPRINT OF MINERALIZATION}

Potassic alteration consisting mainly of secondary biotite and lesser K-feldspar replacement of intrusive rock is narrowly distributed and closely correlated with $\mathrm{Cu}-\mathrm{Mo}-\mathrm{Au}$ porphyry type mineralization at East and West Taurus (fig. 1). Potassic alteration in the Fishhook area differs in that it comprises K-feldspar-quartz alteration of metamorphic rocks. It is not accompanied by the $\mathrm{Cu}-\mathrm{Mo}-\mathrm{Au}$ mineralization, intrusive rocks, or quartz veinlets that are typical of potassic alteration in porphyry systems.

Sericitic alteration is more broadly distributed (fig. 1) and affects a wider variety of rocks. At East Taurus, quartz-sericite-pyrite alteration forms a pervasive zone peripheral to the potassic alteration. In places within the greater Taurus-Bluff area and the Pika-Fishhook area, sericitic alteration affects both intrusive and metamorphic rocks, is discontinuous from outcrop to outcrop, and varies in intensity. The distribution of intermittent sericitic alteration noted by DGGS field geologists forms two generalized clusters, one around Taurus-Bluff and a second in the Pika-Fishhook area (fig. 1).

Tourmaline observed by DGGS field geol- 
ogists occurs in both igneous and metamorphic rocks as disseminations, veinlets, and breccia infills. Tourmaline observations form two broadly generalized clusters: one in the Taurus-Bluff area, and one in the Pika-Fishhook area (fig. 1). For this report we have not made any attempt to discriminate among tourmaline observations based on chemistry, textural style, or other variables, and it is likely that the tourmaline distribution presented in fig. 1 is the combined pattern of multiple original events such as a combination of Late Cretaceous and Paleozoic magmatic episodes.

All varieties of tourmaline contain about 10 percent $\mathrm{B}_{2} \mathrm{O}_{3}$ (Deer and others, 1992). It is, for the purposes of this report, a field-mappable boron anomaly. Boron is an incompatible and volatile element typically enriched in the most evolved magmas, including pegmatites. The distribution of tourmaline found during mapping does not appear to be spatially related to the mapped distribution of mid-Cretaceous granite and pegmatite (unit $\mathrm{Kg}$ ) or Late Devonian to Mississippian Divide Mountain augen gneiss (unit MDag; map sheet 1), although tourmaline may be found in both units. Instead, DGGS tourmaline observations are clustered around the latest Cretaceous TaurusBluff and Pika-Fishhook intrusive centers, both of which appear to root in larger intrusive complexes concealed at depth (see magnetic modeling results, chapter G).

Tourmaline in the Taurus-Bluff area appears to be temporally associated with latest Cretaceous intrusions, even though it only rarely occurs in the proximal $(\mathrm{Cu}-\mathrm{Mo}-\mathrm{Au}$ mineralized) portions of the East and West Taurus prospects. A tourmaline-bearing quartz-sericite-pyrite assemblage at the East Dennison prospect yielded an ${ }^{40} \mathrm{Ar} /{ }^{39} \mathrm{Ar}$ sericite age of $65.8 \mathrm{Ma}$ (Doug Kreiner, U.S. Geological Survey, personal commun., 2018). Intense tourmaline alteration on the ridge north of Taurus is crosscut by latest Cretaceous granodiorite (unit Ktgd; late syn-mineralization at East Taurus) indicating the tourmaline is related temporally to the hydrothermal system (Doug Kreiner, U.S. Geological Survey, personal commun., 2018).

Tourmaline in the Pika-Fishhook area occurs locally within Late Cretaceous igneous rocks, but it is mostly observed in the metamorphic country rock. Gill (1977) identified tourmaline as an alteration mineral locally in granodiorite and andesite (units Kpd and Kv, respectively, of this report). Within a sample of chalcopyrite-bearing granodiorite at the Northeast Pika Canyon prospect, tourmaline rosettes accompany alteration comprising orthoclase replacement of plagioclase, plus lesser sericite, epidote, and carbonate (Gill, 1977). DGGS was not able re-locate this occurrence during this project. In thin sections of metamorphic rocks from this area examined for our project, 1-5 percent tourmaline occurs as a fine (sub-100 to 500 micron) disseminated phase in otherwise unaltered rocks, or as macroscopic, randomly oriented $0.5-1.5 \mathrm{~mm}$ grains within foliation-parallel bands. Two thin sections consistently show tourmaline in trigonal cross section suggesting the mineral could be aligned to a cryptic mineral lineation perpendicular to the plane of the thin section. We did not observe tourmaline partially replacing or forming pseudomorphs of metamorphic minerals such as biotite or hornblende.

\section{DISCUSSION OF LODE MINERAL SYSTEMS}

The Taurus-Bluff and the Pika-Fishhook areas have some important geologic similarities: clusters of shallowly emplaced latest Cretaceous intrusions, scattered to pervasive sericitic alteration of latest Cretaceous age, and scattered "distal" (?) type $\mathrm{Ag}-$ $\mathrm{Pb}-\mathrm{Bi}-\mathrm{As}$ and $\mathrm{Au}$ mineralization. For example, the metamorphic host rock, alteration, and trace-element profile of gold mineralization at Fishhook are similar to the mineralization at Hill 4280 near West Taurus.

The most notable differences between TaurusBluff and Pika-Fishhook are geologic elements that are lacking in the Pika-Fishhook area including significant (mappable) volumes of granitic compo- 
sition intrusive rocks that are closely associated with mineralization at Taurus. Further, DGGS sampling encountered no $\mathrm{Cu}-\mathrm{Mo}-\mathrm{Au}$ mineralization at Pika-Fishhook; although Gill (1977) reported chalcopyrite-mineralized rock, DGGS was unable to re-locate this presumably small occurrence.

Some of the differences between the two areas could be explained by the apparently shallower depth of exhumation in the Pika-Fishhook area. Smaller volumes of intrusive rock are exposed at Pike-Fishhook, and coeval volcanic rocks (i.e., the paleo-surface) are preserved locally. The sulfiderich veins carrying $\mathrm{Ag}-\mathrm{Pb}-\mathrm{Bi}$-As mineralization and the Au mineralization associated with sericite alteration could conceivably be the distal expression of a porphyry system. However, these veins and localized sericite are not the advanced-argillic alteration 'lithocap' described for the near-surface levels above porphyry systems elsewhere in the world (e.g., Sillitoe, 2010).

While both Pika-Fishhook and TaurusBluff areas feature similar clusters of tourmaline observations, the two areas differ in the timing of tourmaline formation. Much of the tourmaline observed in the Pika-Fishhook area may have a pre-metamorphic origin. In the Taurus-Bluff area, tourmaline appears to be spatially and temporally associated with latest Cretaceous intrusions, and we infer that this 'boron footprint' is an expression of the latest Cretaceous magmatic-hydrothermal systems mapped and geophysically modeled at depth in the area.

Finally, the size of the underlying magmatic systems may also help explain the differences between the Taurus-Bluff and Pika-Fishhook areas. Three-dimensional geophysical models accompanying this report (chapter G; figs. 1 and 2) suggest that the mapped intrusions in the Taurus-Bluff area represent only the shallowest expressions of a much larger intrusive complex that is almost entirely concealed. Geophysical models do not show a similar intrusion at depth in the Pika-Fishhook area.

\section{PLACER POTENTIAL}

A small amount of placer gold was produced from Liberty Creek during periods of mining in the 1930s, 1970s, and 1990s. According to the Alaska Resource Data File (ARDF), it is the only creek in the study area with known gold production (U.S. Geological Survey, 2018). The area of mining, as determined from aerial photographs, lies approximately $1 \mathrm{~km}$ downstream of the confluence of a north-flowing tributary that drains the immediate Pika area (fig. 1). Active mining claims extend eastward along the main stem of Liberty Creek approximately $2 \mathrm{~km}$ above this confluence.

There are three possible lode sources for the placer gold in Liberty Creek. The most logical source for the gold is the intrusion-related mineralization in the Pika-Fishhook area (fig. 1), which is described above. A second possible source is the newly mapped Late Cretaceous conglomerate and sandstone (unit $\mathrm{Kc}$ ) at the headwaters of Liberty Creek. Sedimentary rocks of this age are spatially associated with placer gold in the Chicken area (Werdon and others, 2001), and a source from this unit might explain the extension of mining claims above the tributary that drains the Pika Canyon lode prospect. Finally, gold may be sourced from broadly distributed, as-yet-undiscovered auriferous veins hosted by the Fortymile River assemblage, possibly re-concentrated from Neogene to Pleistocene alluvial gravels; this is the geologic model for the Fortymile placer deposits outlined by Yeend (1996).

If intrusion-related mineralization in the Pika-Fishhook area is the source for placer gold, portions of upper East Fork and Sixtymile rivers may be prospective for undiscovered placer resources. Our work seems to indicate that the Fishhook prospect, which is drained by these rivers, has actively eroding gold mineralization at surface. If gold is sourced from Late Cretaceous sedimentary rocks, then placer gold should also occur in tributaries to the Sixtymile River as well as the headwaters of Liberty Creek. 


\section{CRITICAL MINERAL POTENTIAL OF THE STUDY AREA: RHENIUM}

The map area contains significant potential for one critical mineral: rhenium (Re). With an average abundance of less than 1 parts per billion (ppb), Re is one of the rarest elements in Earth's continental crust. It has an extremely high melting point, and thus its primary industrial application is as a component in high-temperature alloys used in jet aircraft engines. Rhenium is produced as a byproduct of $\mathrm{Cu}$ and Mo production, with Chile being the world's leading producer (John and others, 2017). In 2018, the U.S. relied on imports for about 80 percent of its Re consumption (U.S. Geological Survey, 2019).

DGGS geochemical sampling of the study area is the first, to our knowledge, to include low-detection-limit Re analyses (Wypych and others, 2018). These analyses indicate that the East Taurus $\mathrm{Cu}-\mathrm{Mo}-\mathrm{Au}$ prospect contains significant concentrations of Re and could potentially host a resource of this critical mineral. The average Re concentration from 38 samples of East Taurus $\mathrm{Cu}-\mathrm{Mo}-\mathrm{Au}$ mineralized drill core was $525 \mathrm{ppb}$, and the maximum Re concentration was 3,500 ppb. Excluding one high-Re outlier, Re is closely correlated to Mo $\left(\mathrm{R}^{2} 0.91\right)$ and to a lesser extent $\mathrm{Cu}$ $\left(\mathrm{R}^{2} 0.51\right)$. The Re/Mo indicated by these well-correlated samples is 0.0021 .

East Taurus contains an inferred mineral resource of 68 million metric tons grading 0.275 percent $\mathrm{Cu}, 324 \mathrm{ppm} \mathrm{Mo}$, and $0.166 \mathrm{ppm} \mathrm{Au}$ (Harrington, 2010). Assuming a Re/Mo of 0.0021 , the average Re grade of this resource is $672 \mathrm{ppb}$,

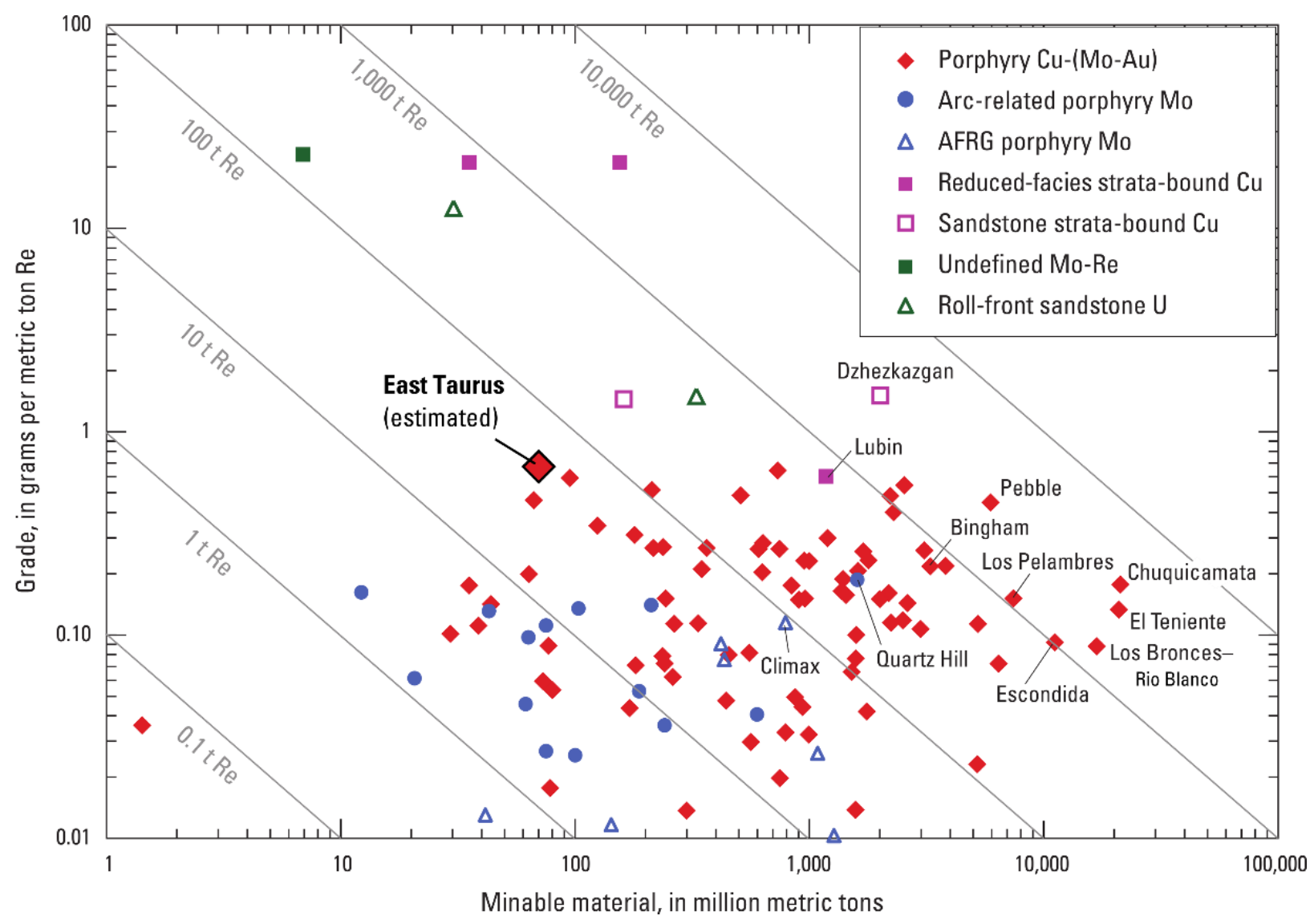

Figure 2. Rhenium grades and resources worldwide by deposit type. Gray diagonal lines are isolines of contained Re in metric tons (t). AFRG: alkali-feldspar rhyolite-granite. Modified from John and others (2017). 
and contained Re totals 46 metric tons. By this extrapolation, Re grades at East Taurus are at the high end of the range for global porphyry copper systems (fig. 2). Future exploration may expand the total Re endowment.

\section{ACKNOWLEDGMENTS}

We thank the DGGS Mineral Resources Section and DGGS staff who contributed to data collection, scientific discussions, and support of this project, Kenorland Resources for access to the historic East Taurus drill core, and Doug C. Kreiner for geologic discussions and review; all of which significantly improved this report.

The DGGS Northeastern Tanacross project was primarily funded by State of Alaska general funds, with supplementary funding from the USGS National Cooperative Geologic Mapping Program under STATEMAP award number G18AC00137 for 2018. The views and conclusions contained in this document are those of the authors and should not be interpreted as necessarily representing the official policies, either expressed or implied, of the U.S. Government.

\section{REFERENCES}

Allan, M.M., Mortensen, J.K., Hart, C.J.R., Bailey, L.A., Sánchez, M.G., Ciolkiewicz, W., McKenzie, G.G., and Creaser, R.A., 2013, Magmatic and Metallogenic Framework of West-Central Yukon and Eastern Alaska, in Colpron, Maurice, Bissig, Thomas, Rusk, B.G. and Thompson, J.F.H, Tectonics, Metallogeny, and Discovery: The North American Cordillera and Similar Accretionary Settings, Society of Economic Geologists Inc. Special Publication 17, p. 111-168.

Burns, L.E., Fugro Airborne Surveys Corp., and Fugro GeoServices, Inc., 2011, Ladue survey area: Magnetic and electromagnetic line, grid, and vector data and Maps, Fortymile mining district, Tanacross Quadrangle, eastern Alaska: Alaska Division of Geological \& Geophysical Surveys Geophysical Report 2011-1, 26 sheets, scale 1:63,360, 1 DVD. doi.org/10.14509/22562
Deer, W.A., Howie, R.A., and Zussman, Jack, 1992, An Introduction to the Rock-Forming Minerals: London, Mineralogical Society of Great Britain and Ireland, 498 p.

Emond, A.M., Saltus, R.W., Graham, Gina, and Goldak Airborne Surveys, 2015, Airborne magnetic geophysical survey of the Tanacross region, Alaska: Alaska Division of Geological \& Geophysical Surveys Geophysical Report 2015-6. doi.org/10.14509/29514

Gill, R.D., 1977, Geology and mineral deposits of the southwest quarter of the Tanacross D-1 Quadrangle, Alaska: Bellingham, Washington, Western Washington University, M.S. thesis, 129 p.

Harrington, Edward, 2010, Technical report on the Taurus property, Fairbanks Recording District, Alaska, U.S.A.: Unpublished NI43-101 report for Senator Minerals Inc., 133 p. (posted on www.sedar.com, Jan. 4, 2011)

John, D.A., Seal, R.R., II, and Polyak, D.E., 2017, Rhenium, chapter P, in Schulz, K.J., DeYoung, J.H., Jr., Seal, R.R., II, and Bradley, D.C., eds., Critical mineral resources of the United States-Economic and environmental geology and prospects for future supply: U.S. Geological Survey Professional Paper 1802, p. P1-P49. dx.doi.org/10.3133/pp1802P

Kenorland Minerals, 2017, Kenorland Minerals Tanacross Project Presentation: Unpublished presentation (Available online at: kenorlandminerals.com/wp-content/uploads/ 2017/04/Kenorland-Tanacross-Oct-2017_ Technical.pdf; last accessed April 5, 2019)

Lerich, P.D., 1995, Taurus copper-molybdenum porphyry deposit, east-central Alaska, in Schroeter, T.G., ed., Porphyry Deposits of the Northwestern Cordillera of North America: Canadian Institute of Mining Metallurgy and Petroleum Special Volume 46, p. 451-457.

Naibert, T.J., Benowitz, J.A., Wypych, Alicja, Sicard, K.R., and Twelker, Evan, 2018, ${ }^{40} \mathrm{Ar} /{ }^{39} \mathrm{Ar}$ data from the Tanacross D-1 and D-2, Big Delta B-4 and B-5, and Mount Hayes A-6 quadrangles, Alaska: Alaska Division of Geological \& Geophysical Surveys Raw Data File 2018-3, 15 p. doi.org/10.14509/30112 
Todd, Erin, Wypych, Alicja, and Kylander-Clark, Andrew, 2019, U-Pb and Lu-Hf isotope, age, and trace element data from zircon separates from the Tanacross D-1, and parts of the D-2, C-1, and C-2 quadrangles: Alaska Division of Geological \& Geophysical Surveys Raw Data File 2019-5, $10 \mathrm{p}$.

Sillitoe, R.H., 2010, Porphyry Copper Systems: Economic Geology, v. 105, p. 3-41.

U.S. Geological Survey, 2018, Alaska Resource Data File (ARDF). https://ardf.wr.usgs.gov [updated March 2018]

-2019, Commodity summary: Rhenium. minerals.usgs.gov/minerals/pubs/commodity/rhenium/mcs-2019-rheni.pdf [last accessed April 5, 2019]

Werdon, M.B., Newberry, R.J., and Szumigala, D.J., 2001, Bedrock geologic map of the Eagle A-2 Quadrangle, Fortymile mining district, Alaska: Alaska Division of Geological \& Geophysical Surveys Preliminary Interpretive Report 2001-3B, 1 sheet, scale 1:63,360. doi. org/10.14509/2670

Wypych, Alicja, Twelker, Evan, Athey, J.E., Lockett, A.C., Naibert, T.J., Sicard, K.R., Werdon, M.B., and Willingham, A.L., 2017, Major-oxide and trace-element geochemical data from rocks collected in the Tanacross C-1, D-1, and D-2 quadrangles, Alaska in 2017: Alaska Division of Geological \& Geophysical Surveys Raw Data File 2017-10, 4 p. doi.org/10.14509/29778

Wypych, Alicja, Naibert, T.J., Athey, J.E., Newberry, R.J., Sicard, K.R., Twelker, Evan, Werdon, M.B., Willingham, A.L., and Wyatt, W.C., 2018, Major-oxide and trace-element geochemical data from rocks collected in 2018 for the Northeast Tanacross project, Tanacross C-1, C-2, D-1, and D-2 quadrangles, Alaska: Alaska Division of Geological \& Geophysical Surveys Raw Data File 2018-4, 4 p. doi.org/10.14509/30113

Wypych, Alicja, Jones, J.V., III, and O'Sullivan, Paul, 2020, U-Pb Zircon ages from bedrock samples collected in the Tanacross D-1, and parts of the D-2, C-1, and C-2 quadrangles, Alaska: Alaska Division of Geological \& Geophysical Surveys Preliminary Interpretive Report 2020-2, 19 p. doi.org/10.14509/30465

Yeend, W.E., 1996, Gold placers of the historical Fortymile River region, Alaska: U.S. Geological Survey Bulletin 2125, 75 p., 1 sheet, scale $1: 63,360$. 


\title{
CHAPTER G: MAGNETIC MODELING OF NORTHEAST TANACROSS
}

\author{
Abraham Emond ${ }^{1}$ and Alicja Wypych ${ }^{1}$
}

\section{INTRODUCTION}

Two magnetic modeling studies were performed to assist with the geologic interpretation of the map area. A sub-regional unconstrained magnetic susceptibility model was produced to compare the depth extent of the magnetic intrusive rocks of the Taurus prospect area and the Pika and Fishhook prospect area. A series of forward magnetic models was created to determine the likely depth extent and dip of the amphibolite and serpentinite (MDlau) unit.

\section{SUB-REGIONAL MODEL}

The unconstrained magnetic inversion of the Northeast Tanacross map area was performed using MIRA Geoscience's VPmg software resulting in a 3D magnetic susceptibility model. The unconstrained model is a merge of a smaller, more detailed inversion and a larger coarser inversion using VPmg's incision option. MIRA Geosciences provided technical support for creating the Northeast Tanacross map area model.

The detailed inversion model of the Northeast Tanacross map area has a horizontal cell size of 100 meters by 100 meters and is 2 kilometers in depth extent. The input data for this model were from the DGGS Ladue survey (Burns and others, 2020). The final regional model was used as the starting model and basement for the map area inversion.

The regional model extends between 18 and 92 kilometers beyond the Northeast Tanacross map area as shown in figure 1. This model has a horizontal cell size of 1000 meters by 1000 meters. The input data for the regional model was from the Alaska and Yukon magnetic compilation (Oneschuk and others, 2019). These data were upward continued to 500 meters by DGGS staff prior to performing the inversion. Three regional inversions with different starting models were calculated. The starting magnetic susceptibility was $100 \times 10^{-3} \mathrm{SI}, 10 \times 10^{-3} \mathrm{SI}$, and $1 \times 10^{-3} \mathrm{SI}$. A starting model of $10 \times 10^{-3} \mathrm{SI}$ was used for the final regional model.

Figure 2 shows an oblique view of the final Northeast Tanacross map area 3D model. The magnetic model is shown as a susceptibility shell with a value $17.5 \times 10^{-3}$ SI that encloses modeled values greater than $17.5 \times 10^{-3} \mathrm{SI}$. The susceptibility shell is colored by elevation. Important prospects, magnetic geology, the project area, and select waterways are also included in figure 2 . The modeled magnetic body is tens of kilometers in horizontal extent and 15 or more kilometers in depth, and extends to the south and below the Bluff and Taurus prospects as seen in figures 1 and 2. In contrast, the Pika and Fishhook prospects sit on a smaller magnetic body that is a few kilometers in horizontal and vertical extent. The regional models show a larger and deeper magnetic body associated with the Taurus prospect regardless of the starting magnetic susceptibility of the regional model. The root of the VABM Lode unit is also visible in figures 1 and 2 .

\section{AMPHIBOLITE AND SERPENTINITE (MDlau) UNIT MODELS}

A series of forward models were performed on the magnetic signature of the amphibolite and serpentinite (MDlau) unit shown in figures 1 and 2. These forward models were performed to provide geometrical and orientation constraints on the geobody associated with the observed magnetic anomaly. The forward models were performed using MIRA Geoscience's VPmg software. The model geometries were created from an inter-

${ }^{1}$ Alaska Division of Geological \& Geophysical Surveys, 3354 College Rd., Fairbanks, Alaska 99709-3707. 


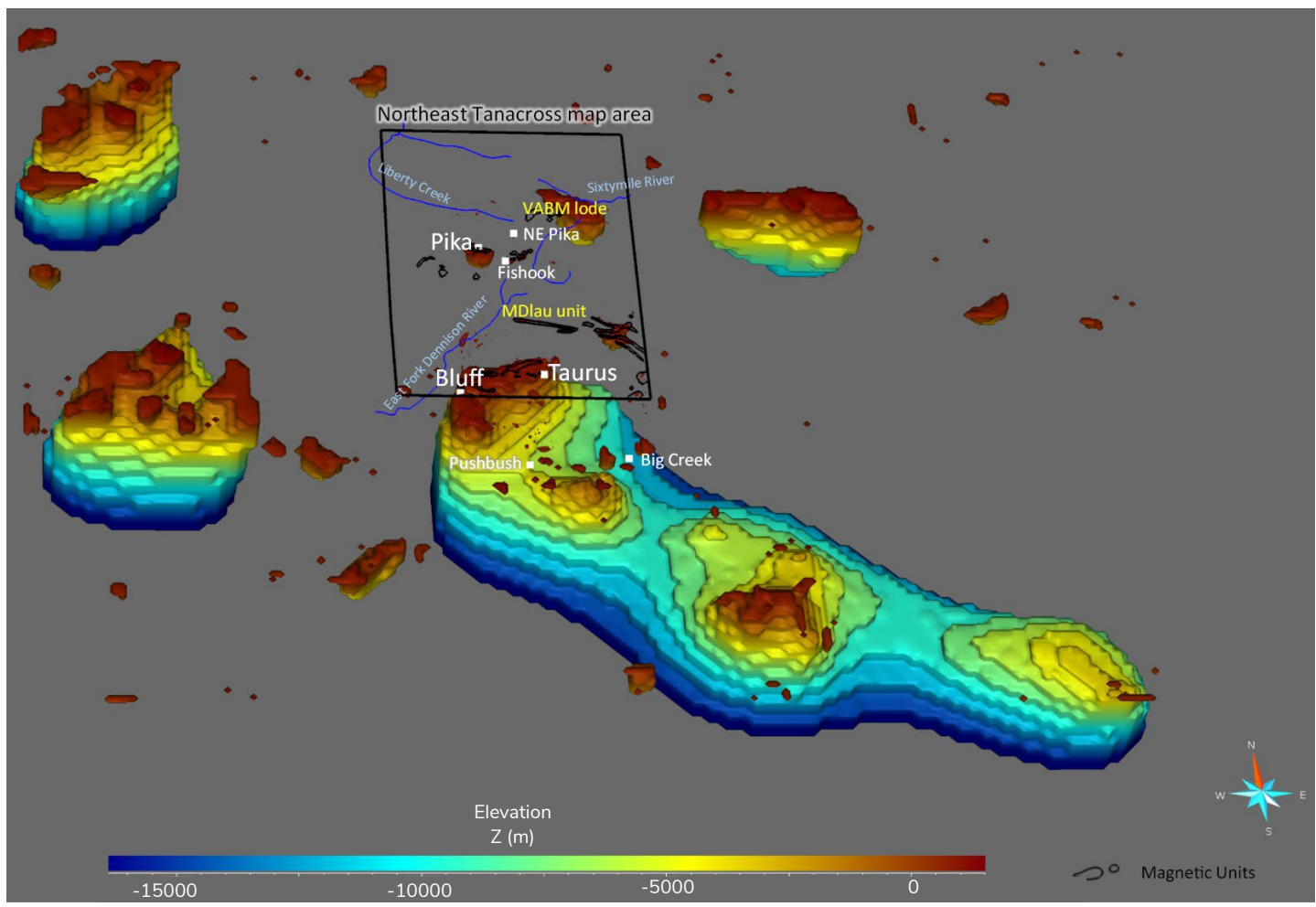

Figure 1. Aerial view of the final regional 3D model. The magnetic model is shown as a susceptibility shell with a value of $17.5 \times 10^{-3} \mathrm{SI}$. The susceptibility shell is colored by elevation relative to mean sea level. The project area is shown with important geologic features, prospects, and select waterways.

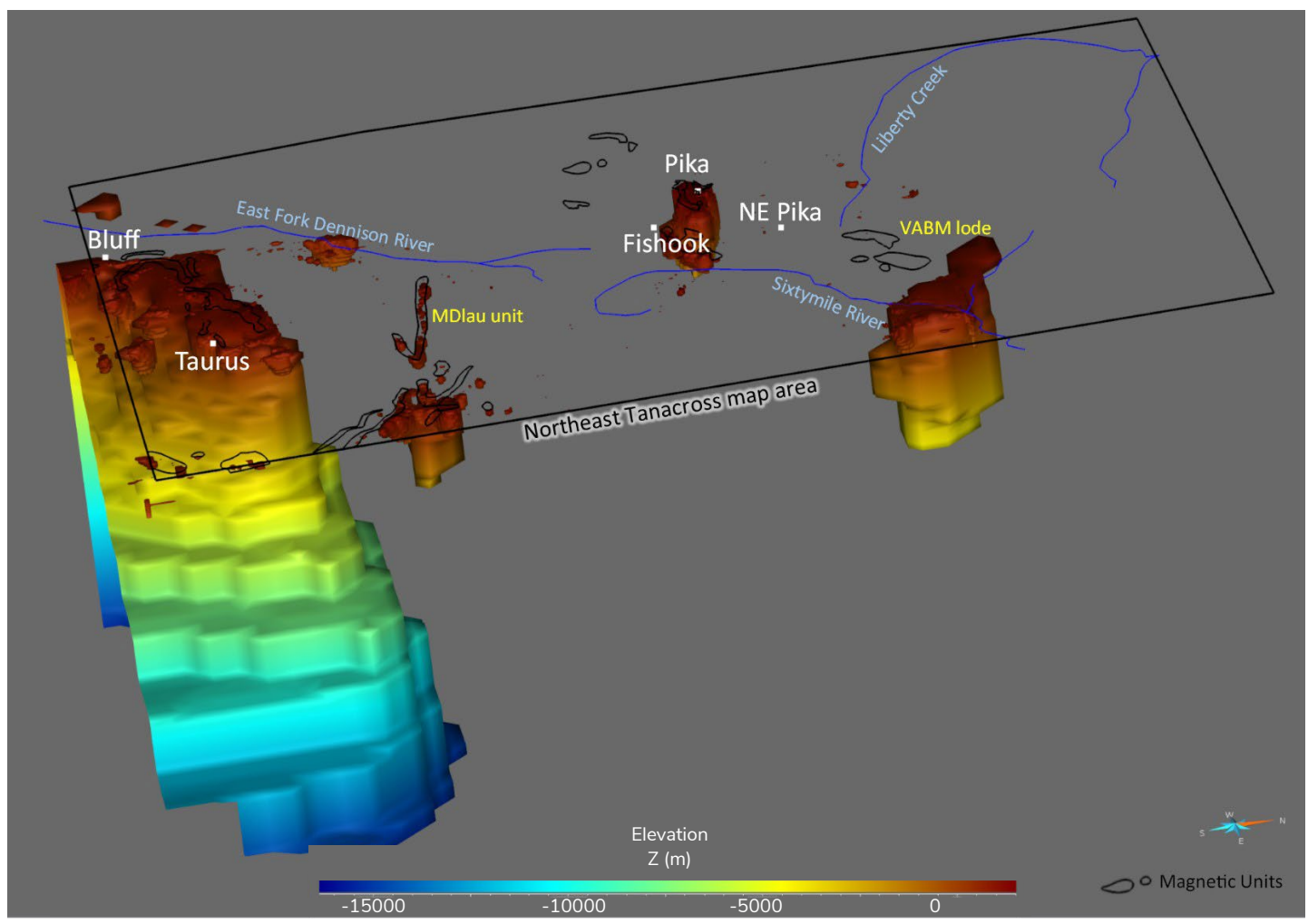

Figure 2. Final magnetic susceptibility model of the Northeast Tanacross map area shown as susceptibility shell with a value of $17.5 \times 10^{-3} \mathrm{SI}$. The susceptibility shell is colored by elevation. The project area is shown with important geologic features, prospects, and select waterways. 
preted surface expression of the geobody. Eight models were produced using the "Rapid Potential Field modeling of 3D dipping bodies" function of VPmg. The forward modeled data were compared qualitatively to the observed data for magnetic anomaly shape and quantitatively for anomaly amplitude. Magnetic susceptibility values from 38 outcrop samples ranged from $0.02 \times 10^{-3}$ SI to $88 \mathrm{x}$ $10^{-3} \mathrm{SI}$ with a mean value of $8.6 \times 10^{-3} \mathrm{SI}$.
Figure 3 shows the eight forward models produced using VPmg. Models that dip steeply to the north show the best fit based on anomaly appearance. Models with magnetic susceptibility of $10 \times 10^{-3}$ SI did not produce an anomaly with the same magnitude as the recorded data. The 120-meter-thick, 60-degree-north-dipping model produced an anomaly of similar magnitude and shape to the recorded data. The MDlau unit is

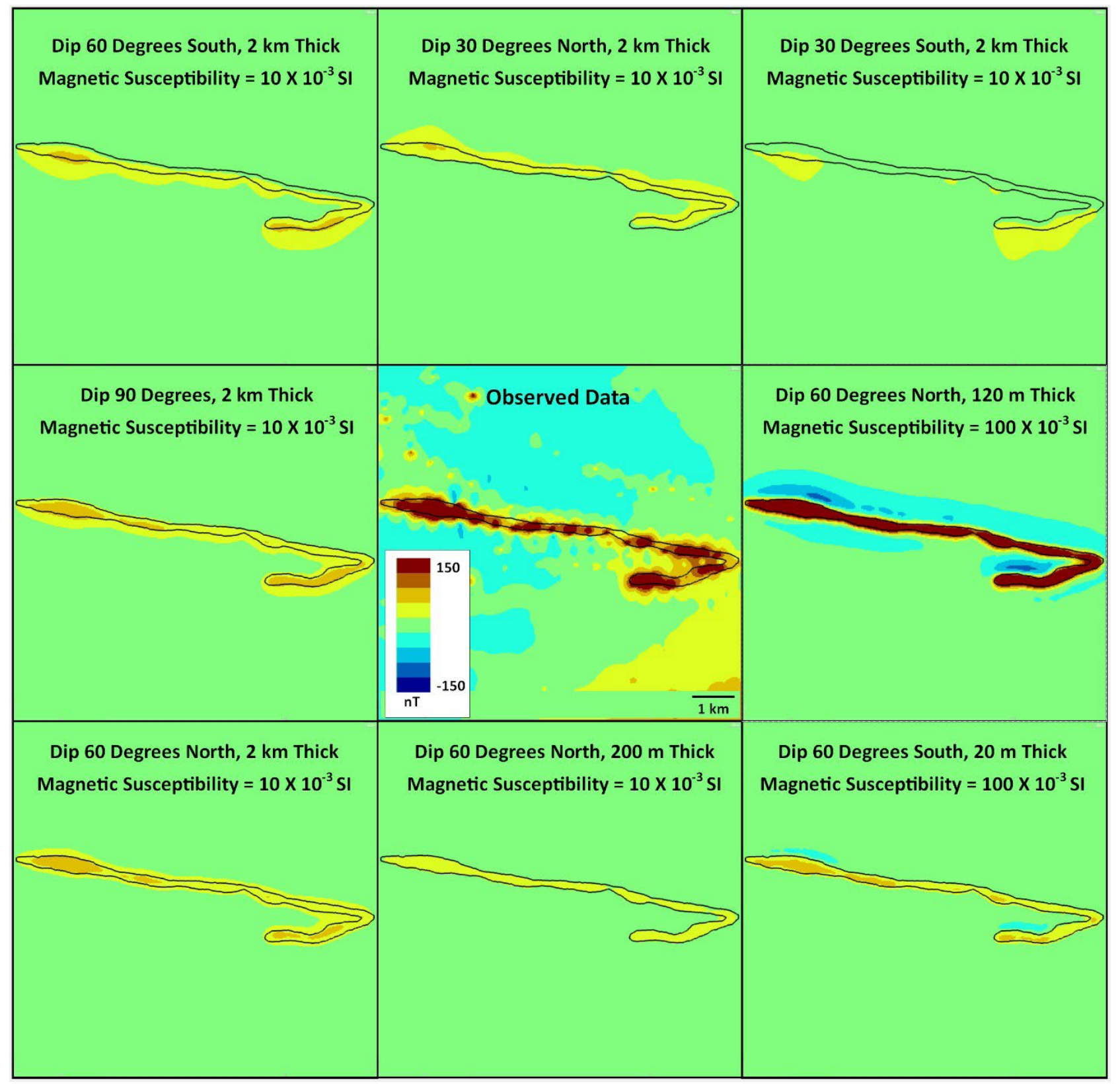

Figure 3. Results of eight forward magnetic models. Residual magnetic data are shown. The image in the center shows the observed data. All magnetic data share the same colorbar and map-scale. 
interpreted as dipping steeply to the north, with a depth extent of more than 100 meters and a magnetic susceptibility greater than $10 \times 10^{-3} \mathrm{SI}$.

\section{SUMMARY}

The sub-regional unconstrained inversion shows a thick and large magnetic body under the Taurus prospect region. Magnetic bodies under the Fishhook and Pika prospects are isolated and have smaller depth extents. The thick magnetic body beneath the Taurus region is truncated at the Sixtymile fault that follows the East Fork Dennison and Sixtymile Rivers. Its magnetic signature is consistent with both Late Cretaceous Taurus granodiorite (Ktgd). The Taurus-Bluff area contains locally abundant secondary magnetite, veins of which may be found in the Late Cretaceous intrusions as well as in the surrounding rock (Doug C. Kreiner, personally commun., 2020), another element adding to the magnetic signature of the region.

The magnetic forward models indicate the amphibolite and serpentinite (MDlau) unit is greater than 100 meters in thickness and dips steeply to the north. We interpret this body to be a dike due to the steep dip of the body, its thickness, cutting relations with the Lake George augen gneiss (MDag), and its Mississippian age (Wypych and others, 2020).

Results of geophysical models modeling are inherently non-unique. Other models than those presented may fit the data.

\section{ACKNOWLEDGMENTS}

The author would like to thank the DGGS Mineral Resources section and DGGS staff who contributed to data collection, scientific discussions, and other necessary support for this report, as well as Robert Gillis and Ben Drenth for helpful reviews of this chapter. The DGGS Northeast Tanacross project was primarily funded by State of Alaska general funds and the USGS National Cooperative Geologic Mapping Program under STATEMAP award number G18AC00137 for 2018. The views and conclusions contained in this document are those of the authors and should not be interpreted as necessarily representing the official policies, either expressed or implied, of the U.S. Government.

\section{REFERENCES}

Burns, L.E., Graham, G.R.C., Barefoot, J.D., Naibert, T.J., Fugro Airborne Surveys Corp., and Fugro GeoServices, Inc., 2020, Ladue electromagnetic and magnetic airborne geophysical survey data compilation: Alaska Division of Geological \& Geophysical Surveys Geophysical Report 2019-20, 15 p. doi.org/10.14509/30261

Oneschuk, D., Miles, W., Saltus, R., and Hayward, N., 2019, Alaska and Yukon magnetic compilation, residual total magnetic field: Geologic Survey of Canada Open File 7862, 1 sheet. doi.org/10.4095/313537

Wypych, Alicja, Jones, J.V., III, and O'Sullivan, Paul, 2020, U-Pb Zircon ages from bedrock samples collected in the Tanacross D-1, and parts of the D-2, C-1, and C-2 quadrangles, Alaska: Alaska Division of Geological \& Geophysical Surveys Preliminary Interpretive Report 2020-2, 19 p. doi.org/10.14509/30465 